\title{
Response to Intervention Implementation: The Successes and Challenges in the Mid Appalachian Counties
}

\author{
Tammy J. Samples \\ West Virginia University
}

Follow this and additional works at: https://researchrepository.wvu.edu/etd

\section{Recommended Citation}

Samples, Tammy J., "Response to Intervention Implementation: The Successes and Challenges in the Mid Appalachian Counties" (2013). Graduate Theses, Dissertations, and Problem Reports. 112.

https://researchrepository.wvu.edu/etd/112

This Dissertation is protected by copyright and/or related rights. It has been brought to you by the The Research Repository @ WVU with permission from the rights-holder(s). You are free to use this Dissertation in any way that is permitted by the copyright and related rights legislation that applies to your use. For other uses you must obtain permission from the rights-holder(s) directly, unless additional rights are indicated by a Creative Commons license in the record and/ or on the work itself. This Dissertation has been accepted for inclusion in WVU Graduate Theses, Dissertations, and Problem Reports collection by an authorized administrator of The Research Repository @ WVU.

For more information, please contact researchrepository@mail.wvu.edu. 
Response to Intervention Implementation: The Successes and Challenges in the Mid Appalachian Counties

\title{
Tammy J. Samples
}

\author{
Dissertation submitted to the \\ College of Education and Human Services \\ at West Virginia University \\ in partial fulfillment of the requirements \\ for the degree of
}

\author{
Doctor of Education \\ in \\ Curriculum and Instruction \\ Allison Swan Dagen, Ph.D., Chair \\ Aimee Morewood, Ph.D. \\ Patricia Obenauf, Ed. D. \\ Charline Barnes-Rowland, Ed.D. \\ Karen Petitto, Ed.D.
}

Department of Curriculum and Instruction/Literacy Studies

Morgantown, West Virginia

2013

Keywords: Response to Intervention, Stakeholder Perceptions, Tier Instruction, IDEA, West Virginia

Copyright 2013 Tammy J. Samples 


\section{ABSTRACT \\ Response to Intervention Implementation: The Successes and Challenges}

\section{Tammy J. Samples}

Education reform has been on a new path over the last 15 years; a path that leads to more accountability, more choice for students and parents, highly qualified teachers, as well as, best practices in instruction. In an effort to move along the path of reform and as a result of previous reform, the 2004 reauthorization of IDEA reviewed the field of literacy instruction and disability determination.

They found that the Intelligence Quotient (IQ) discrepancy model was problematic and often put students in a position of waiting to fail due to the fact that placement often did not occur until students had passed through the primary grades. One of the most sweeping reform efforts designed to impact student achievement can be found in the Response to Intervention (RTI) initiative. RTI is an innovative approach to literacy and language instruction that is designed to deliver instruction in a three-tiered delivery model with increasing levels of intensity.

The purpose of this study was to gauge the implementation level of the nationally mandated RTI initiative in three West Virginia (WV) counties with respect to the following stakeholders classroom teachers, reading specialists, special education teachers, and principals. The following areas-Assessment, Instruction, Collaboration and Problem Solving, Professional Development, and Special Education Referral and Eligibility procedures - were used to assess implementation. Data were collected using a survey instrument designed using language presented in the WV Department of Education RTI project.

Little common ground was found between administrators and teachers on multiple areas of implementation. While this was highlighted within the survey results, the survey did not solicit specific reasons for the lack of congruence. The use of effective communication implies that schools that implement RTI successfully, spend necessary time in collaboration with all stakeholders. Burns and Gibbons (2012) agreed that the discussion about RTI must continue to inform decision making.

Within the survey results, patterns emerged with regard to the following areas:

- personnel,

- time constraints and scheduling,

- professional development,

- appropriate funding and resource allocation.

Survey results concluded that stakeholder position does effect perceived implementation status and that numerous variables impact implementation. Within the survey results, patterns emerged 
with regard to the following areas: personnel, time constraints and scheduling. While it is clear from the survey results that the elements of time, staffing, and funding are problematic; it is also evident that school administrators are unaware of these concerns as corroborated by the disjointed responses from administrators and teachers. 


\section{DEDICATION}

This dissertation is dedicated, first and foremost, to my parents who instilled in me the desire to learn. They have always supported me in whatever educational endeavor I have attempted. I am greatly indebted to them for their love, support, and encouragement throughout this process.

This achievement is also dedicated to my nieces and nephews - Kirstie, Hunter, Toddy, Trapper, and Katie. All the work I do in education is viewed through the "Aunt" lens - how can I improve educational practice to benefit you and the students who follow. Special gratitude and appreciation go to my brother and sisters, who gifted me with their children and allowed me to be an integral part of their lives.

I also dedicate this dissertation to the support system of friends and colleagues who have provided a shoulder to cry on, proofreading, pep talks, and have completed any number of other duties.

I could not have done it without you! Much love to all. 


\section{ACKNOWLEDGEMENT}

I would like to thank my advisor, Dr. Allison Dagen, who has supported me from the beginning, with pep talks, multiple revisions, emails, and phone calls. To the other members of the committee, Dr. Aimee Morewood, Dr. Charline Barnes Rowland, Dr. Patricia Obenauf, and Dr. Karen Petitto, thank you for joining my committee as it evolved over my time at WVU. You each brought special skills and perspectives that made my work better.

I am especially thankful to Dr. Cathy Fisher who started this journey with me. She has always been a cheerleader on the sidelines keeping me focused and moving forward. Without her, I am not sure I would have made it. To my colleagues, Tracie Dodson, Shirley Fortney, and Karen Petitto, thank you for the encouragement, support, and the occasional "kick in the pants." Special thanks to Tammy Crites, who guided me through the statistical analysis. To my friends, Susan Dillon, Jody Johnson, and Karen Moas thanks for the shoulders to cry on and the many words of encouragement.

To the many students that I have taught over the years, please know that what I do every day I do for you and the students who come after you. You inspire me to go to work every day.

Finally, my deepest gratitude goes to all the administrators and teachers who were willing to participate in my study and trusted me to share their thoughts and perceptions about Response to Intervention. Without them, this work would not be possible. 


\section{TABLE OF CONTENTS}

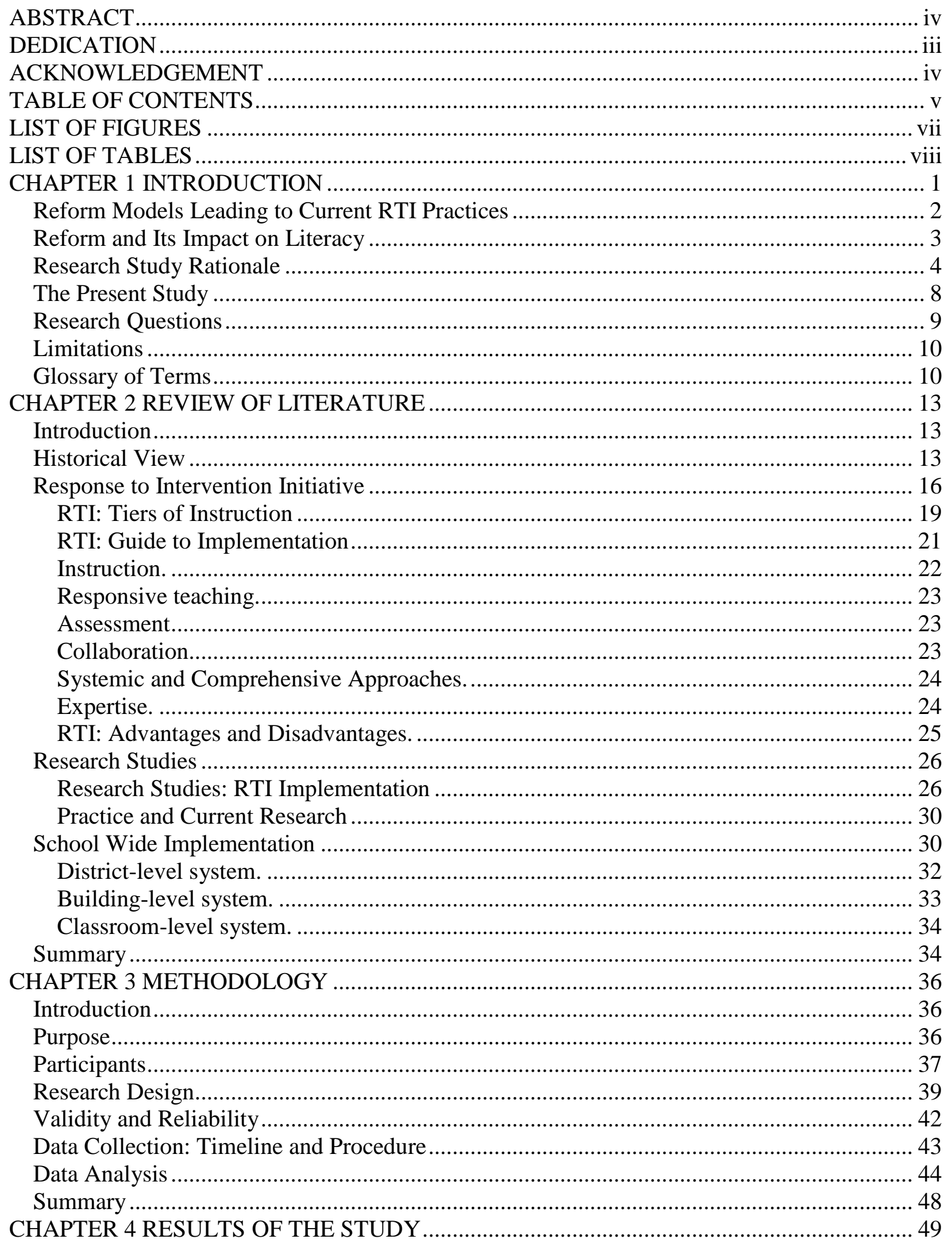




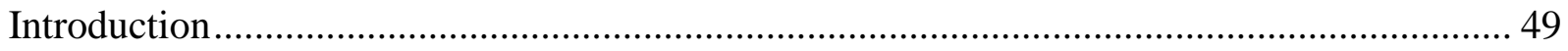



Research question one: Implementation status............................................................ 51

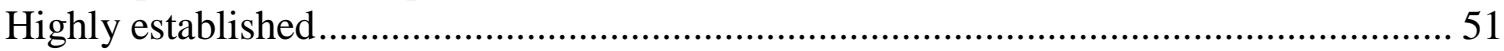

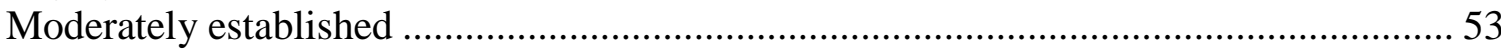

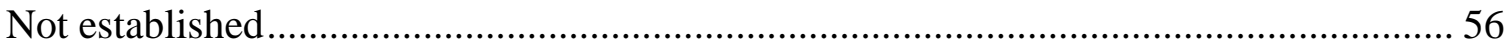

Research question two: Stakeholder involvement in the implementation process............... 57

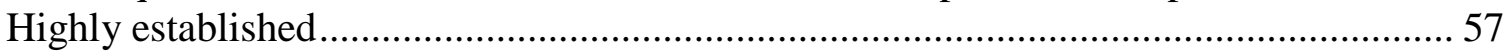

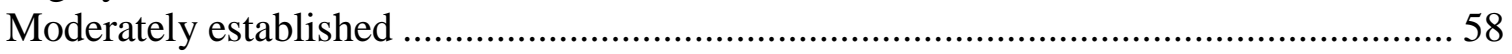

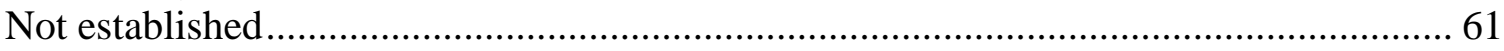

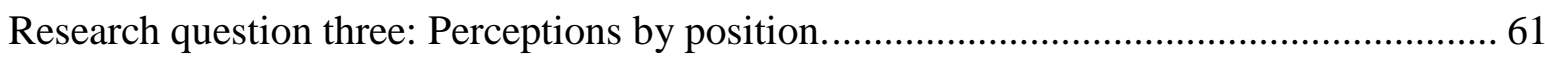

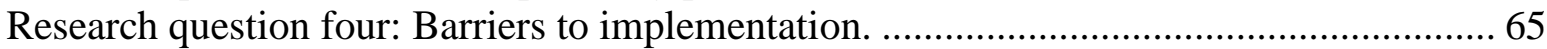

People

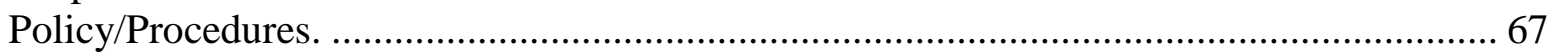

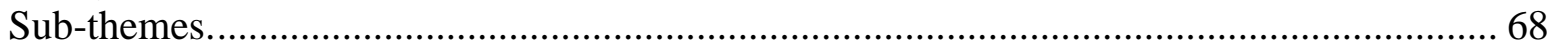

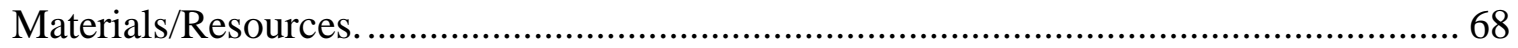

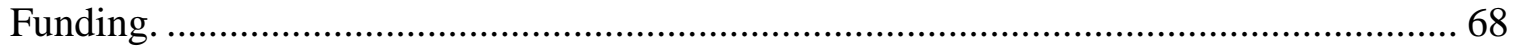



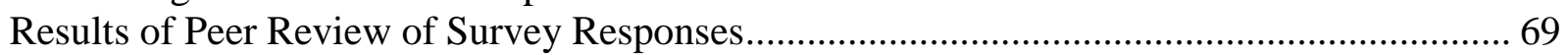

CHAPTER 5 CONCLUSIONS, RECOMMENDATIONS, SUMMARY ………………........... 71

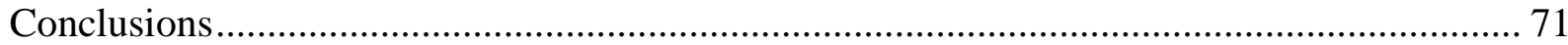

Conclusion I: Stakeholder position does effect perceived implementation status................. 71

Conclusion II: Numerous variables impact implementation. ............................................. 72

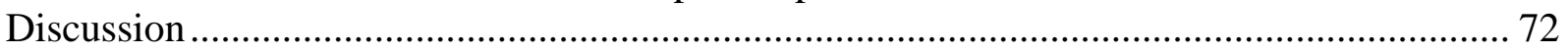

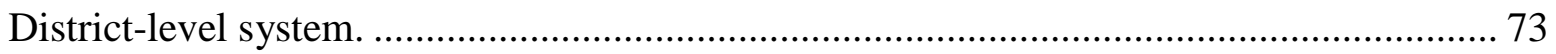

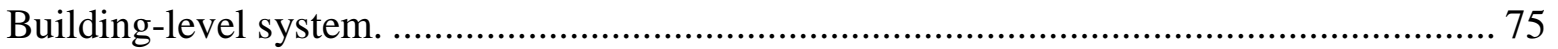

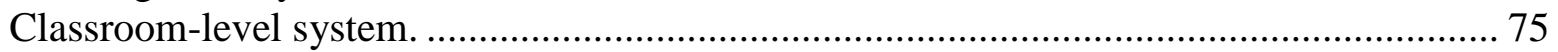

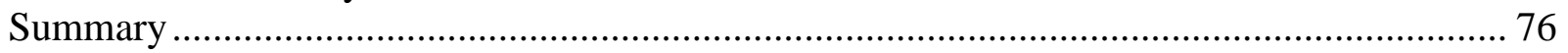

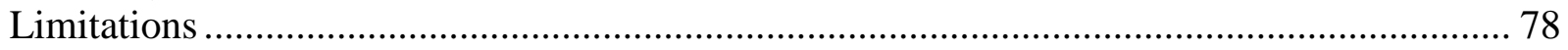

Recommendations for Further Research..................................................................... 80

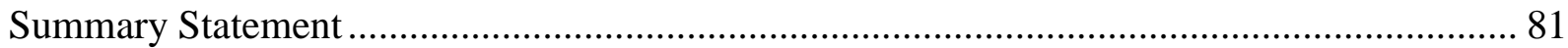

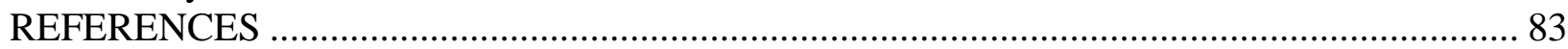



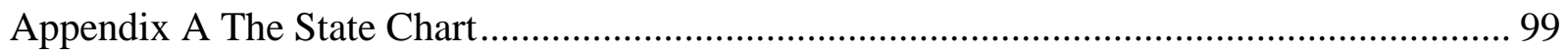

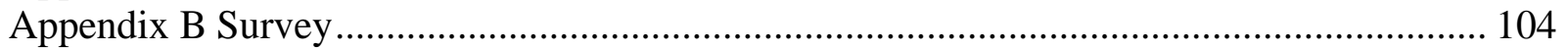

Appendix C Response to the Intervention Checklist ........................................................ 118

Appendix D District Level Implementation Status Rubric .................................................... 120

Appendix E School Readiness for RTI: A Self-Assessment ................................................... 122

Appendix F Response to Intervention Process: Implementation Status Report at Elementary



Appendix G Panel of Experts .............................................................................. 128

Appendix H RESA Support Letter ............................................................................... 130

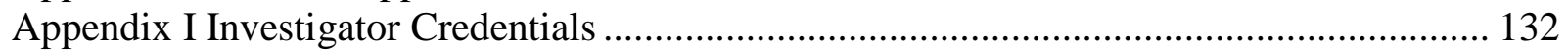

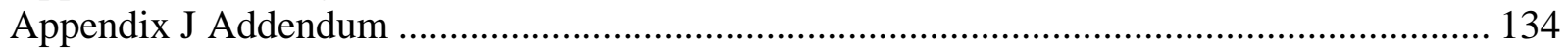




\section{LIST OF FIGURES}






\section{LIST OF TABLES}

Table 1 Participating County Demographics ........................................................................ 37

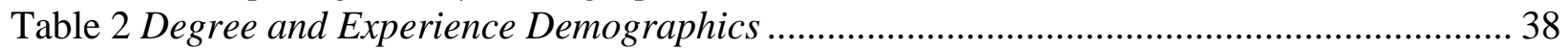

Table 3 Survey Instrument and Research Question Analysis ........................................................ 46

Table 4 Survey Items: Highly Established by All Stakeholders ................................................ 52

Table 5 Survey Items: Moderately Established …………..................................................... 55

Table 6 Survey Items: Not Established by All Stakeholders ...................................................... 56

Table 7 Survey Items: $51 \%$ or Higher Established by All Stakeholders.................................... 58

Table 8 Survey Items: Mixed Ratings of 51\% or Higher Established .......................................... 60



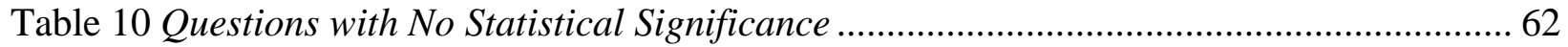

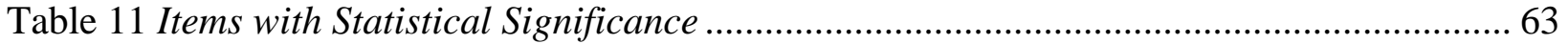

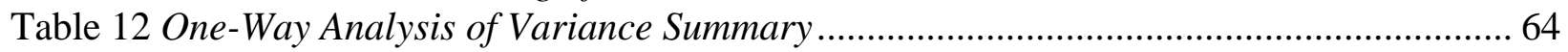

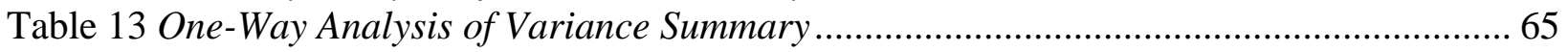

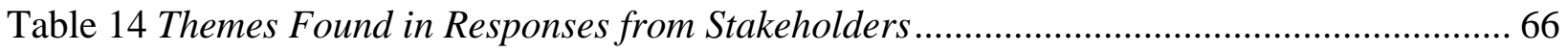

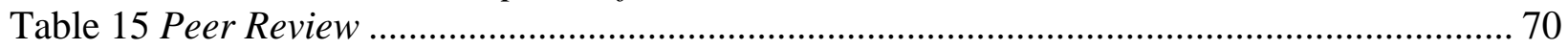




\section{CHAPTER 1}

\section{INTRODUCTION}

"The idea of education reform is not new, and reforms and reformers have come and gone ...America's public schools essentially have remained unchanged in the way they deliver education and the manner in which they are organized" (Allen \& Dale, 1995, p. 3). While this statement holds some truth, education reform has been moving forward over the last 15 years; this move leads to more accountability, more choice for students and parents, highly qualified teachers, as well as, best practices in instruction. Reform, at its heart, is a complex entity that requires much from the stakeholders involved in the process (Stone, Orr, \& Worgs, 2006). Stone, Orr, and Worgs believe that reform is not about putting programs into place, but about sustaining an innovation that requires all stakeholders to change their practice as well as determine new and innovative ways to finance change. According to Fullan (2007), “...in terms of responsibility, individual classroom teachers cannot opt out of school reform; individual schools cannot opt out of district reform; individual districts cannot opt out of state reform; and individual states cannot opt out of global reform" (p. 303). Currently two reform efforts are being simultaneously implemented in the United States. The Response to Intervention (RTI) initiative is an innovative approach to literacy and language instruction that is designed to deliver instruction in a threetiered delivery model with increasing levels of intensity. More recently implemented, the Common Core State Standards (CCSS) initiative is designed to provide a concise picture of what students need to learn and how stakeholders can move them forward. RTI and CCSS both use data analysis and intervention to provide students with proper instruction. 


\section{Reform Models Leading to Current RTI Practices}

Fullan's (2009) analysis of the history of educational reform demonstrates a variety of quality ideas and policy initiatives that result in failure of implementation, or that experience success in one location but not in others. "The ultimate goal of change is for people to see themselves as shareholders with a stake in the success of the system as a whole..." (Fullan, 2009, p. 303). With that in mind, Fullan (2009) notes that when traveling the road to school improvement, it is best to remember that it can be filled with potholes that make navigation difficult and that can dramatically alter your arrival time.

The road to education reform and policy implementation has seen numerous education acts and their subsequent reauthorizations. Most notably, this journey began with the passage of the Elementary and Secondary Education Act (ESEA) in 1965, which provided for the education of low income children and created special programs such as Title I (Sass, 2010). This movement continued with the 1975 Education for All Handicapped Children Act (EAHCA), which afforded children with disabilities a diagnosis, and provided a free appropriate education designed to enhance educational experiences (Johnston, 2010; Sass, 2010). The 1990 reauthorization of the EAHCA as the Individuals with Disabilities Education Act (IDEA) deepened the definition of learning disability, as well as, changed the terminology from handicap to disability. Even though changes were occurring with learning disabilities in the late 1990's, Reutzel and Mitchell (2005) postulate that at this time in history, both the opinions of the public and political arena believed that "literacy instruction... was thought to be in dire need of reform" (p. 607). 


\section{Reform and Its Impact on Literacy}

The No Child Left Behind (NCLB) Act of 2001, is the reauthorization of the ESEA of 1965. The reauthorization of this landmark legislation changed the scope of education for all stakeholders. One major facet of NCLB is increased accountability for schools and districts in order to meet standards of Adequate Yearly Progress (AYP) in Reading and Mathematics. Failure to meet AYP can affect the second facet of NCLB, which is school choice. As a result of these guidelines, parents are presented with school choice, which allows them to choose a different school setting if their current school fails to meet AYP. Other aspects of NCLB allow for some autonomy in the use of educational funds, as well as curriculum guidelines that support the use of scientifically-based research in the instruction of literacy. This promotes the notion that teachers should be highly qualified for the positions they hold. While NCLB has been an asset that emphasizes what should be happening in education, the journey to effective school reform needs to continue due to the fact that there are imperfections in the current design (Gunning, 2010).

In an effort to move along the path of reform and as a result of previous reform, the 2004 reauthorization of IDEA reviewed the field of literacy instruction and disability determination and found that the Intelligence Quotient (IQ) discrepancy model was problematic and often put students in a position of waiting to fail due to the fact that placement often did not occur until students had passed through the primary grades (Fuchs \& Fuchs, 2006; Johnston, 2010). IDEA (2004) states that local educational entities "may use a process that determines if the child responds to scientific, research-based intervention as part of the evaluation procedures..." (Section 1414(b)(6)). These changes became the impetus behind the RTI initiative. "RTI is an initial attempt to provide an alternative to the dominant and damaging discrepancy model in 
which so much time is spent admiring the student's reading problem" (Mesmer \& Mesmer, 2008, p. 289). Brown-Chidsey and Steege (2005) propose that the current RTI initiative provide an opportunity to determine where a child is performing and the level at which that child needs to be. Therefore, the problem becomes less about the child, but more about what occurs with the child and the educational environment. Hardcastle and Justice (2006) concur and suggest that with RTI there is a shift from the idea of a child waiting to fail towards realignment with a "process that responds before a child experiences significant delays" (p. 8). In their position statement on RTI, the International Reading Association's (IRA, 2010) Commission on RTI states that "RTI is not a model to be imposed on schools but rather a framework to help schools identify and support students before difficulties they encounter with language and literacy become more serious" (p. 1). While RTI characterizes a potential method of "addressing many issues associated with specific learning disabilities identification, unanswered implementation questions remain” (Johnson, Mellard, Fuchs, \& McKnight, 2006, section 1, p. 1.4). Fullan (2007) postulates that in order to successfully implement reforms, a reciprocity must exist between implementation plans, follow through, and the processes of planning. "The most effective intervention will not produce positive effects if it is not implemented. Therefore, performance assessments are a critical component related to RTI implementation" (Fixsen, Naoom, Blase, Friedman, \& Wallace, 2005, p. 55).

\section{Research Study Rationale}

To summarize, with the legislation requirements found in NCLB (2001) and the advent of the 2004 reauthorization of IDEA, the mode of delivery for reading instruction dramatically changed. NCLB required increased accountability for teachers, required the use of scientificallybased reading research, gave parental choice with regard to low performing schools, increased 
autonomy, with regards to, funding for states and districts, and placed an emphasis on reading at an early age. Building on the momentum of NCLB, the reauthorization of IDEA forever changed the manner in which specific learning disabilities are diagnosed. Heretofore, the process for identifying a specific learning disability involved finding a discrepancy between a child's current level of achievement and his tested IQ (Fuchs, Fuchs, \& Vaughn, 2008). Utilization of this approach, identification is often made when children are about to enter the intermediate level of elementary school. Within this framework, children are often made to "wait to fail" before services could be offered (Fuchs, Fuchs, \& Vaughn, 2008). This necessitated a change in the manner in which learning disabilities were determined.

The reauthorization of IDEA (2004) offers an alternative means of assessment and perhaps the demise of the discrepancy model of identification. The language in IDEA states that when "...determining whether a child has a specific learning disability, a local educational agency may use a process that determines if the child responds to scientific, research-based intervention as a part of the evaluation procedures" $(\$ 118.2706(6)(\mathrm{B}))$. This legislation, referred to as RTI, acts as a catalyst to focus on intervention and provide a blueprint for the school district's plan for intervention. Johnston (2010) reports that the law defines RTI in two ways: "as a strategy for identifying students with learning disabilities, replacing the IQ discrepancy identification approach, and as a strategy for reducing the number of students who end up with disabilities" (p. 602). Mesmer and Mesmer (2008) conclude that “...RTI is a process that incorporates both assessment and intervention so that immediate benefits come to the student" (p. 287). Sailor (2009) believes that RTI "is best understood as a model used to guide efforts to teach (intervention) based on measures of pupil progress (response) and grounded in the idea of prevention" (p. 3). 
While the definitions vary, all can agree that RTI is a process designed to provide instruction that meets the needs of all students. Allington (2009) noted,

Underlying the RTI initiative is the research on early intervention that suggests that many struggling early readers can be caught up to grade level and that currently too many of these students are simply classified as pupils with learning disabilities. Too many are classified without ever having participated in any intensive early intervention. (p. 19)

Howard (2009) declares "the intent of RTI is to ensure that students receive rich literacy experiences every year in every setting with every teacher, not merely some years in some settings with some teachers" (p. 15). Howard believes we are at an impasse; RTI has the potential to be a panacea for the woes of our educational system with regard to student achievement and special education placements.

Current research indicates a need for further research. Since the 2004 reauthorization of IDEA, the publication of books, articles, how-to manuals, and implementation guides covering every aspect of RTI have flooded the field of education. Experts in the field (Allington, 2009; Fuchs, Fuchs, \& Vaughn, 2008; Johnson, Fuchs, McKnight, \& Mellard, 2006) have weighed in on how to implement the program, what features must be in place for effective implementation, and how the initiative relates to educational reforms. Even state departments of education have joined the clamor, and worked to create positions to oversee implementation, as well as, created implementation guides for use by local schools and boards of education. The National Center on Response to Intervention website personnel developed a document, The States Chart (see Appendix A) that shows what each state uses for RTI protocol and how each state measures implementation with regard to the four following questions: 
Does the state have a State RTI Framework?

Does the state have RTI Components in its State Performance Plan?

Does the state have an RTI-related State Professional Development Grant?

What does the state allow for Specific Learning Disability? (National Center on Response

to Intervention State Database, 2009)

Many of the states that have implementation frameworks in place for RTI models mandated by IDEA (2004), have RTI components listed in their State Performance Plans, as well as, have a process for determining special education placement. The state of West Virginia began implementation of RTI in 2005 with emphasis placed on the primary grades K-3 (WVDE, 2007). The Office of Special Programs developed both a guide and timeline for implementation. At the time of this research West Virginia could answer all four of the aforementioned questions.

Despite the fact that progress is shown across the United States in the implementation processes and adherence to the provisions, as stated in IDEA (2004) with relation to RTI, very little research has been conducted about the levels of implementation and the status of implementation in districts and states. While some resources offer self-checks and implementation checklists, as well as, status rubrics to ascertain implementation, often only district or state level stakeholders are surveyed (Hoover, Baca, Wexler-Love, \& Saenz, 2008; Werts, Lambert, \& Carpenter, 2009). Kellar-Marguilis (2012) suggests that consistent examining of implementation will provide the necessary information to move implementation processes forward. Rinaldi, Baker, and Averill (2013) also speak to the need for fidelity of implementation, but state as the implementation is happening quickly, implementation fidelity can be 
compromised. Pending more extensive research on the implementation process that involves all stakeholders, from teachers through county and state level administration, implementation will remain stagnant without guidance from those who are in the trenches. While guidelines of implementation processes have been established, county boards of education were in varying levels of implementation.

\section{The Present Study}

The purpose of this study is to gauge the implementation level of the nationally mandated RTI initiative in West Virginia (WV) with respect to the following stakeholders - classroom teachers, reading specialists, special education teachers, and principals. The following areasAssessment, Instruction, Collaboration and Problem Solving, Professional Development, and Special Education Referral and Eligibility procedures—will be used to assess implementation. These areas arise from the West Virginia Department of Education (WVDE) RTI Implementation Status Rubric (2008) and are a result of the guidelines for implementation listed in the West Virginia Response to Intervention: An Implementation and Technical Assistance Guide for Schools and Districts (2006). This study also sought to establish what participants (classroom teacher, special education teacher, reading specialist) were responsible for delivery of intervention in each tier. At this time, few studies on implementation exist (Hoover, Baca, Wexler-Love, \& Saenz, 2008; Kimmel, 2008; Werts, Lambert, \& Carpenter, 2009). Findings are mixed; however, implementation fidelity did surface in each study.

This study gathered perceptions of stakeholders (classroom teachers, special educators, reading specialists, literacy coaches, principals and county level administration) on the implementation status of RTI in elementary and middle schools in the state of WV. Data were collected using a survey instrument designed using documentation of implementation from the 
WV Department of Education RTI project. Stakeholder perceptions were analyzed using open questions to invite free response within voluntary interviews.

This research is relevant to the field of education for multiple purposes. The main purpose of this study was to determine stakeholder perceptions of the implementation processes of RTI. While RTI implementation began in earnest approximately seven years ago, limited research on the implementation processes exists. Keller-Marguilis (2012) used the term fidelity of implementation in reference to the many facets of RTI implementation. The author remarked that while stakeholders know fidelity is important, a consensus as to the best way to measure implementation is currently absent. This research has the potential to improve the implementation process for other sites in the implementation process by conveying the problems that occurred. In view of the fact that little research exists on the implementation processes and status, the following questions were presented to multiple stakeholders:

\section{Research Questions}

1. To what extent are stakeholders (superintendents/other district personnel, coaches, principals, classroom teachers, reading specialists, special education teachers) involved in the implementation process as per the RTI Implementation Checklist developed by the WVDE?

2. To what extent do stakeholders rate their implementation status:

a. (Not in Place, Emerging, Making Progress, Established) as defined by the District Level RTI Implementation Status Rubric developed by the WVDE in the areas of
a. assessment,
b. instruction,
c. collaboration and problem solving, 

d. professional development,
e. Special Education Referral and Eligibility Procedure?

3. In what ways do the perceptions of stakeholders (superintendents/other district personnel, coaches, principals, classroom teachers, reading specialists) differ as a result of the position they hold?

4. What components (e.g. school, district, state leadership; professional development; data analysis; resources; funding) have delayed the implementation of RTI?

\section{Limitations}

One potential limitation is the methodology for this study is exclusively self-reported data. Due to the fact that the survey is unsupervised and self-administered, participants do not have the opportunity to ask questions if a survey item is unclear (Bourque \& Fielder, 2003). Another possible limitation was the time of the school year when the survey was administered. As the survey was administered at the beginning of the 2008 school year, attitudes could have been more positive because participants had just returned from summer break and, therefore, the results could have been skewed. An additional limitation was related to the response/return rate. Bias could have been created because a large number of surveys were not returned.

\section{Glossary of Terms}

Adequate Yearly Progress (AYP) - a level of success on yearly assessments that requires schools to meet certain benchmarks

Discrepancy Model - this model determines whether a discrepancy exists between a student's intelligence and his academic achievement 
Elementary and Secondary Education Act (ESEA) - an act from President LB Johnson's "War on Poverty" (1965), this far reaching act was intended to reduce the achievement gap and provide opportunities to all students. The Title I Federal Program was instituted as part of ESEA.

Education for All Handicapped Children Act (EAHCA) - Public Law (PL) 94-142, An act that required all schools that received federal funds to provide equal access to education for all students with disabilities - mental or physical, and educational plan and provided parents an avenue to question decisions made that pertained to students with disabilities.

Highly qualified - a teacher is considered Highly Qualified if they hold certification for the state in which they teach, possess a bachelor's degree from a four year institution, and demonstrates competence in the areas in which they teach.

Implementation status - the level at which schools determine they are implementing RTI Individuals with Disabilities Education Act (IDEA) - A federal law designed to safeguard services to students with disabilities. Services included early intervention and special education reauthorized in 2004.

Intelligence Quotient (IQ) - measure of intelligence resulting from a battery of assessments

Learning Disabled (LD) - significant delays in academic areas .

No Child Left Behind (NCLB) - A federal act established in 2001 to ensure that all students reach a proficient level on standardized testing by the year 2013-2014. This act also created more accountability for states and schools. Adequate Yearly Progress (AYP) is also a facet of NCLB that requires schools to meet certain benchmarks with yearly assessments.

PSM - an intervention program used to address the needs of low performing students, prior to referral for Special Education 
Progress Monitoring - assessment given to Tier II and III students in the interim between Universal Screening times

Response To Intervention (RTI) - a multi-tier intervention program used to provide varying levels of instruction to students who are struggling academically

Scientifically based reading research - research that possesses rigor and objective protocols that promotes knowledge both relevant and reliable to educational programs

Stakeholder - all groups involved in RTI (classroom teachers, reading specialists, special educators, building level administrators, county level administrators)

Tier I - first level of instruction delivered to all students in the regular classroom setting

Tier II - second level of instruction delivered to a small number of students who are strategic (slightly below benchmark) delivered in a small group setting in groups of six or fewer

Tier III - third level of instruction delivered to a group of three or fewer students who are intensive (significantly below benchmark)

Universal Screening - assessment given to all students three times a year

West Virginia Policy 2419 - a policy designed to regulate the education of students with exceptionalities 


\section{CHAPTER 2}

\section{REVIEW OF LITERATURE}

\section{Introduction}

This literature review will address the historical view of special education identification, the definition of RTI and the early programs, as well as review RTI implementation protocols. RTI implementation continues to evolve and change as processes and procedures improve.

\section{Historical View}

"Public law 94-142 defines a specific learning disability as a disorder in one or more of the basic psychological processes involved in understanding or using language, spoken or written, which may manifest itself in an imperfect ability to listen, think, speak, read, write, spell, or to do mathematical calculations" [P.L. 94-142, 121a. 5b (9)] (p. 28). Across the United States, the process for determining learning disabilities has historically used the intelligence achievement discrepancy criterion. Previously, children who experienced difficulty in literacy and language were subjected to the discrepancy model of identification, which often led to a delay in the delivery of services, which in turn, resulted in a more severe reading problem. Fuchs, Fuchs, and Vaughn (2008) found that over the last forty years, the most common practice for identifying children for special education services used the discrepancy model. Bradley, Danielson, and Doolittle (2005) added that since the learning disability category was established in 1977, those students diagnosed with a disability has grown to more than $200 \%$. Gresham (2007) posited that educators began to separate and serve those students who demonstrate inconsistent abilities and experiences. However, he also pointed out those students "learn to be learning disabled" (p. 17), when in essence their deficiency is a lack of exposure to beginning literacy skills. Berkeley, Bender, Peaster, and Saunders (2009) reported that this significant 
increase which occurred in Special Education led some educators to believe misdiagnosis could be a factor. Discontent with the IQ discrepancy model helped to initiate research in this area.

The ability to prevent learning difficulties at the first evidence of struggle is a powerful concept (Forman, 2007). While the goal of education is to provide quality instruction, the delay in placement hinders this goal. Bradley et al. (2005) insist that the main concern at this point is ensuring that the students who need special education are getting services in a reasonable time frame. Gresham (2007) used the term "refer-test-place" (p. 10), as the manner in which students are placed in special education. A pattern surfaced, in which, students were referred to a specialized team that suggested ways to help manage the issue. The suggested strategies were then implemented but the methods used were often not research-based and student failure was imminent without fidelity within and across the interventions. This process means that as students wait for services; they are in essence waiting to fail (Fuchs, Fuchs, \& Vaughn, 2008). When student failure occurs, students are then referred to a school psychologist for testing and then frequently placed in special education when the discrepancy between their academic performance and their intellectual potential manifests.

The wait-to-fail method allowed learning difficulties to go unchecked and unnoticed. A discrepancy may exist but may not be severe enough to qualify for services (White, Polly, \& Audette, 2012; Wright, 2007). This indicates that some difficulty exists, but there was not enough discrepancy between student scores and what is considered appropriate for special education placement. Often students were neglected for so long that they were eventually placed in special programs, not necessarily because of cognitive deficiencies, but because help was not given when it was needed (Wedl, 2005; White et al., 2012). These students were often left behind in the reading classroom because they could not keep up with the pace set for and by 
other students. Hence, they were waiting for approximately three years to be tested again which resulted in their placement into special education as a result of a lack of instruction rather than a definitive special education problem. Allington (2007) stated that what had been traditionally termed a reading difficulty has been renamed a learning disability. This allows for an intersection of the fields of reading/RTI research and special education which enables interchangeable terminology.

Gresham (2007) suggested three criteria for assessing the validity of special education classification. They included the quality of the general education program, the ability of the special education program to produce reasonable outcomes for children, and the precision of the assessment process. Compton, Fuchs, Fuchs, and Bryant (2006) expressed concern over this assessment process with regard to the discrepancy model of identification of learning disabilities. Vellutino, Scanlon, and Zhang (2007) suggested the following problems with the discrepancy model: little disparity between students with cognitive deficits and those with environmental or instructional deficits and instrumentation that has little validity (p. 185). Kratochwill et al. (2007) suggested that these issues result in many students who would be good candidates for special education services who are not being identified or placed in special education.

The Intelligence Quotient (IQ) discrepancy model of identification has proven to be ineffective at providing students the necessary skills to become better readers (Wright, 2007). The IQ quotient was detrimental to students because placement was delayed until students reach extremely low levels of performance. Torgesen et al. (2001) stated that the identification of a specific learning disability often occurs at a point in students' educational careers when remediating deficiencies is most difficult. Educators were discovering new ways of defining how they think about students who struggle. Contemporary approaches provided assistance earlier 
and more intensively, and decreased the number of students referred for special education. Therefore, scholars, educators, and policy makers alike were working toward a method of instruction that would assist in early recognition of delayed learning and interventions that would serve as an alternative to Special Education placement.

Gersten and Dimino (2006) gave a thorough history of the "interventions" mandated by policy to be used by special education educators and their students. He stated that over the years many models have attempted to correct or at the very least improve the reading of special education students. This attempt is often met with failure. According to Gersten and Dimino, this newest approach to intervention addresses the needs of students with reading difficulties and has a small body of research that seems promising. A report by Compton et al. (2006) stated that the 2004 reauthorization of IDEA provides an alternative to the IQ-discrepancy model for the identification of specific learning disabilities in students.

\section{Response to Intervention Initiative}

In this section, many of the variable definitions of RTI will be offered. RTI is a service delivery model designed to provide varying tiers of intervention/instruction to students in Reading. The tiers address the needs of all students. Tier I instruction is provided to all students in the regular classroom during the reading block. Tier II is delivered to those students performing slightly below level in reading, offered beyond the regular reading block, generally five times per week for 30 minutes. Tier III intervention is delivered to those students performing significantly below level in reading, beyond regular reading instruction, five times per week for 45 to 60 minutes. Contrasting views can be found in the current research.

The 2004 reauthorization of IDEA allowed for the use of RTI, an approach that proposes that students who do not respond to appropriate and quality instruction, may possess a 
predisposition for learning disabilities. RTI has many assets, all focusing on student success. This research-based process allowed for earlier identification of learning disabilities, a strong focus on quality, effective instruction, and a decision making process sustained by frequent progress monitoring. Legislation set the stage for the next step in education research and the use of RTI as a means for the identification of students with learning disability. Tucker and Sornson (2007) reported that to provide greater success for all students, it is necessary to offer intervention early and efficiently. This early success laid the foundation for future learning accomplishments. Keller-Margulis (2012) stated that the opportunity to establish RTI as a learning disability indicator opened avenues for schools to approach student ability and learning differently.

The Response to Intervention (RTI) approach, a new conceptualization also known as the Problem Solving Model (PSM) (Brown-Chidsey \& Steege, 2005), is an intervention program used to address the needs of low performing students, prior to referral for Special Education. The approach used graduated intervention with children who struggled academically prior to making a referral for special education service (Brown-Chidsey \& Steege, 2005). Gresham (2007) stated that this method of intervention can be delivered in two different modes, which are "standard protocol and problem solving" (p. 14). Standard protocol is an approach used to devise instruction that focuses on areas of weakness, and provides appropriate intervention, as well as, experience with scientifically based reading research. The problem solving approach is, "a standard set of empirically supported instructional approaches...implemented to remediate academic problems" (Jimerson et al., 2007, p. 4). Both Gresham and Jimerson et al. suggested optimal results when using these together because both approaches strive to identify reading deficits and improve them. 
RTI has been defined in a variety of ways. The International Reading Association Commission on Response To Intervention Guiding Principles (2010) defined RTI as “a comprehensive systemic approach to teaching and learning designed to address language and literacy problems for all students through increasingly differentiated and intensified language and literacy assessment and instruction" (p. 1). The Commission believed that RTI should be viewed as a framework to assist schools in their efforts to improve reading for all students, rather than a compulsory model. Brown-Chidsey and Steege (2006) stated that RTI is an examination of the relationship between academic and behavioral interventions and student outcomes as a result of intervention. Kratochwill et al. (2007) referred to RTI as the use of evidence based interventions geared to focus on the needs of students to gauge progress over time with regard to learning and behavior. Gresham (2001) defined RTI, as the changes that ensue in a student's academic performance or behavior with quality intervention. Barnett, VanDerHayden, and Witt (2007) referred to RTI as an approach that addresses intervention intensity and outcomes for children. Mellard and Johnson (2008) saw RTI as a process of instruction, assessment and intervention that makes the advent of student success more palatable. Denton, Fletcher, Anthony, and Francis (2006) stressed the value of early intervention/instruction to thwart reading difficulties. Fuchs and Fuchs (2009) added that RTI can be viewed in two ways—-an approach to early intervention and a method of disability identification" (p. 250). Fuchs and Bergeron (2013) defined RTI as an initiative that has the potential to drastically transform educational practices for all stakeholders. While many of the previously listed definitions provided many aspects of RTI, the definition provided by Bradley et al. (2005) sums up the preceding definitions nicely and provides a congealed definition of a method that emphasizes quality 
instruction, monitored progress, additional assistance to non-responders (students not responding to treatment), and special education referrals for those who continue to struggle.

RTI: Tiers of Instruction. This approach featured three levels or tiers (See Figure 1) of increasing specificity and intensity of instruction. It is designed as a multi-tier approach in which students receive intensive interventions based on collected data (Brown-Chidsey \& Steege, 2005). This model was designed to move in tandem with the regular reading curriculum. Tier I occurs within the regularly scheduled reading time, with Tiers II and III occurring beyond the scheduled, daily reading block.

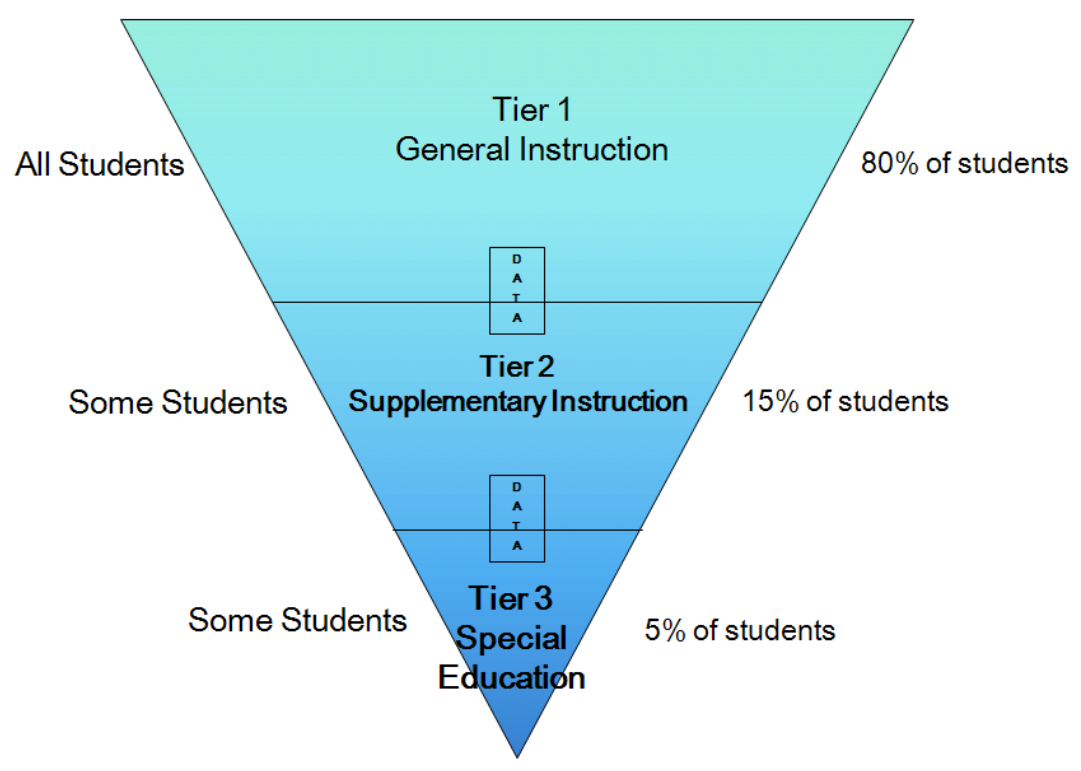

Figure 1.

Tiers of instruction.

Note. Adopted from Brown-Chidsey, R., \& Steege, M. W. (2006). Response to intervention:

Principles and strategies for effective practice. New York: The Guilford Press.

Generally, RTI is delivered in a tiered delivery model. While some schools use multiple tiers (three, four), most programs use the three-tier delivery model. The section below will 
provide a brief overview of each tier, as well as, service delivery time, length of intervention and details related to movement within the tiers.

In Tier 1 (stage 1, universal), all students are serviced within the general education classroom using research based practices and materials (Bollman, Silberglitt, \& Gibbons, 2007; Graden, Stollar, \& Poth, 2007; Peterson, Prasse, Shinn, \& Swerdlik, 2007). Tier II (stage 2, supplemental), intervention is provided for students who fail to meet yearly benchmarks. These students are provided strategic instruction in a small group setting that varies from 8-20 weeks across the programs (Bollman et al., 2007; Graden et al., 2007; Peterson et al., 2007). Tier III (stage 3, individual), assistance is provided for those students who fail to make progress in regards to the intervention they are receiving. These interventions are delivered either one-to-one or one-to-three across the programs (Bollman et al., 2007; Graden et al., 2007; Peterson et al., 2007).

Tier I takes place with all students in the regular education classroom during a 90-minute instructional block. This tier is intended to meet the needs of all students with attention given to accommodations, differentiated instruction, classroom routines, and the core reading program (Fuchs \& Fuchs, 2009). When students fail incremental baseline data collections, interventions become more intensive and occur outside of the scheduled reading block. Tier II instruction includes daily instruction of 30 additional minutes for students who are below benchmark targets for a period of eight to twenty weeks. Progress monitoring should occur at least once weekly during this time (Brown-Chidsey \& Steege, 2005). As stated in Brown-Chidsey and Steege, "frequent assessment of student progress has been shown to be important for effective instructional decision making" (p. 77). If students are not showing adequate progress a new method of intervention is needed within the Tier II framework. 
If students do not show adequate improvement with progress monitoring during Tier II instruction, Tier III intervention will begin. Tier III intervention provides smaller group size, increased instructional time, continuous monitoring of student progress, and indefinite time limitations. Students who reach Tier III may require additional testing to determine specific learning difficulties.

RTI: Guide to Implementation. Since the 2004 reauthorization of IDEA, an influx of commercialized, procedural, how-to manuals for practitioners has flooded the scene, with regards to, RTI and its significance on student outcomes (Allington, 2009; Dole, 2004; Fuchs \& Fuchs, 2006; Johnston, 2010; IRA, 2010; Mellard \& Johnson, 2008). Mellard and Johnson (2008) discussed the difficulty of implementing reform initiatives due to different interpretations and agendas, which resulted in a poorly implemented program that did little to assist struggling learners. McLaughlin (1989) stated that within the scope of policy outcomes it is essential that stakeholders create capacity and a marriage of knowledge across groups to create and sustain the reform effort. The ability of all stakeholders to buy in and move forward with change is tantamount to a successful initiative. Many of the sources provided limited information on the implementation processes and evaluation of the implementation. In this section, an explanation of RTI implementation will be provided related to the IRAs Commission on Response to Intervention Position Statement and its relationship to successful implementation. This guide outlines six guiding principles on implementation and sustainability of RTI. These are important because they were used in the development of the survey instrument used in this study.

This guide contained a series of guiding principles for educators designed to provide information to teachers, special educators, reading specialists and administrators on the implementation and sustainability of RTI (IRA, 2010). The six key principles included 
- instruction,

- responsive teaching,

- assessment,

- collaboration,

- $\quad$ systemic and comprehensive approaches, and

- expertise.

The purpose of these six key principles is to assist educators when considering their work in relation to RTI and its use in thwarting student difficulty in language and literacy, as well as, providing instructional guidance to teachers. O'Connor and Freeman (2012) reported that many schools have encountered successes in implementation with regard to procedures and policies and data collection, however, the student achievement piece continued to create problems for schools.

Instruction. In an effort to provide quality instruction, these areas must be consideredinstruction must meet the needs of all children, a quality core program is in place, research-based interventions must be used, instruction must relate to all students, teachers must be highly qualified and have the ability to modify instruction, as needed, based on assessment results. Smith and Desimone (2005) defined highly qualified “as full certification, a bachelor's degree, and demonstrated content knowledge in all core subjects" (p. 75). Current research supports the notion of scientifically based research and quality professional development as key issues that affect the delivery of language and literacy instruction (Dole, 2004; Johnston, 2010; Mesmer \& Mesmer, 2008). Walker-Dalhouse et al. (2009) quantified that use of high quality, intensive instruction that has been designed and differentiated for each student can positively impact reading achievement. 
Responsive teaching. Within this principle, instruction must be differentiated and targeted to the needs of the struggling student. Differentiated instruction refers to the process of providing students with multiple ways to approach learning and acquire new learning. The focus must be placed on the students and their needs, and be a porous environment that flows from student achievement to teacher instruction. Lose (2007) agreed that it is necessary for interventions to be rigorous and specifically designed for each child.

Assessment. In order to be meaningful, the following criteria must be met—assessments must be valid, provide relevant information, and meet the needs of each student. A shared responsibility between teachers and specialists must be apparent, a variety of assessments must be used, and assessments should be uniform, with regard to, the IRA/National Council of Teachers of English (NCTE) Standards for Assessment of Reading and Writing. Johnston (2010) spoke to the Standards for the Assessment of Reading and Writing (NCTE, 2009) when he referred to the importance of assessment. Assessment is the link that connects teaching and learning. Johnson believed that the teacher is at the heart of assessment and that the teacher's ability to use the assessment data will result in better instruction and increased learning from students. Risko and Walker-Dalhouse (2010), agreed that assessment should be plausible and functional. Risko and Dalhouse continued by listing three areas that can enhance and fine tune the assessment process - using assessments that test more than one skill, the use of formative assessments, and creating assessments that focus on multiple modalities. "Assessments can transform instruction by providing timely information that captures students' strengths, needs, and specific instructional history" (Risko \& Walker-Dalhouse, 2010, p. 420).

Collaboration. Collaboration is an often neglected aspect of reform. Leonard and Leonard (2003) state that there is a great need for schools to focus on collaboration and collegial 
interaction. A solid relationship must exist, between all stakeholders, to ensure collaborative efforts. Within this effort, data should be reviewed and discussed by all stakeholders; coaches and literacy specialists should have expert roles; data should act as an enhancement for instruction; and parents and students should become valued stakeholders. Moore and Whitfield (2009) discussed the idea of building capacity and its direct link to collaboration. The collegiality that grows from an initiative of this nature allows for a free flow of information, creating a field of experts on the topic at hand.

Systemic and Comprehensive Approaches. "RTI must be part of a comprehensive, systemic approach to language and literacy assessment and instruction that supports all preK-12 students and teachers" (IRA, 2010, p. 3). As a result of this principle, the ramifications for RTI should include - instruction based on best practices in literacy and language, relevance to the needs of each school, shared participation by all stakeholders, demonstration of skills appropriate for different grade levels, adequate funding sources, strong leadership, and high quality professional development. Research from the field supports the importance of quality professional development (Dole, 2004; Fullan, 2007; Lose, 2007). While, Walker-Dalhouse et al. reiterated the significant influence on professional development within the implementation of system change. Additionally, the role of the school leader is very important within the span of systemic and comprehensive approaches. Fullan (2009) felt that principals are "key to successful school improvement" (p. 135) and that leadership is often a neglected party in reform implementation.

Expertise. Expertise can be found in the following areas - teachers who are highly qualified, the use of pertinent instructional strategies, an ability to read and use data and assessments to augment teaching, a strong core program, teachers who are culturally responsive, 
and teachers who are willing to learn new ideas and strategies and use them to improve their teaching for all students. Lose (2007) spoke to this in that she suggested that in order to best assist students, teachers must be able to make "moment-by-moment teaching decisions" (p. 277). Johnston's (2010) Instructional Frame for RTI listed expert teaching as a central goal of RTI. He suggested that proficiency in literacy learning and teaching is vital for student success.

RTI: Advantages and Disadvantages. Advantages of an RTI approach include early identification through universal screening, focus on student results, and reduction of biases associated with gender, socioeconomic status, and minority groups (Gresham, 2007). The core concepts of RTI are discussed in length in Jimerson, Burns, and VanDerHeyden (2007) and Bradley et al. (2005). These concepts included high quality, research based instruction, universal screening, continuous progress monitoring, and research based interventions with high fidelity to instruction and implementation (McMaster \& Wagner, 2007). This approach can be implemented in a number of ways. Brown-Chidsey and Steege (2006) stated that RTI is a "prevention based model" (p. 144) including primary, secondary, and tertiary interventions that include efficient instruction, progress monitoring, and review of the results to design instruction. Van Kraayenoord (2007) was quick to discuss some disadvantages of the RTI model. One major concern voiced by Van Kraayenoord was that often when people are discussing RTI they use the term literacy, but often are actually referring to reading. She believed that a lack of literature is inherent in the current RTI models. Another area of concern dealt with the focus on skills, rather than reading as a process, which contributed to another concern related to the use of packaged programs that are often scripted, and therefore, difficult to tailor to specific student needs 


\section{Research Studies}

In this section RTI research will be addressed with regard to practice, student outcomes, and implementation. Although research regarding RTI started $10-15$ years ago, it is still considered to be in the early stages. Current research related to RTI recounts current programs taking place across the United States. The information includes types of programming, as well as, screenings that are occurring. Minimal information is provided on the implementation procedures. This information is provided to create a framework for the current study. At this point in time, the majority of research on RTI is related to student outcomes as a result of implementation. Preliminary results indicated an increase in student achievement in the areas of literacy and learning.

Research Studies: RTI Implementation. Prior to 2010, research on implementation was limited. Much of the research at that time was focused on the process of starting implementation, not on whether fidelity was reached with implementation. The more recent research, after 2010, display more information about implementation, but reiterate the earlier research in that while the implementation processes are in place there is still incongruity between successful implementation practices. Fidelity of implementation in RTI is needed and necessary.

Keller-Margulis (2012) states that much of the research that exists on RTI relates to the notion of special education referral, as opposed to the fidelity of implementation. She suggests that RTI models have been implemented quickly, but cautions that implementation success can take three to five years. Keller-Margulis found that while in some fields fidelity of implementation is best practice, as in school psychology, it is often neglected in intervention programs at the school level. that the suggest when determining implementation status, three domains should be considered - assessment, instruction/intervention delivery, and decision 
making. She suggests that all stakeholders, from all levels who are engaged in the implementation processes and procedures be included in determining key components and in the monitoring process.

Berkeley, Bender, Peaster, and Saunders (2009) completed a snapshot of RTI implementation of all 50 states by reviewing state department websites and having conversations with a representative from state department. Their multiple findings included:

- Professional development that is delivered sporadically and at various levels;

- Many issues exist about multiple tiers (some use three tiers, some two tiers), assessment tools;

- Eligibility process lacks consistency;

- Found 15 states had well developed models, one of which was WV, with 22 remaining in the development phase.

Nunn and Jantz (2009) focused on RTI and teacher efficacy beliefs. This study investigated the relationship between implementation processes and self-efficacy of teachers. The research by Nunn and Jantz did find support for the notion that implementation processes and procedures were connected to efficacy beliefs. The following implications of teacher perceptions and efficacy were found. To begin with, participant perceptions of their skill level indicated a direct link between that level and their efficacy. Subsequently, teacher efficacy was determined to be multifaceted and with further knowledge of the types of efficacy, the RTI process could be positively influenced. Lastly, allowing teachers to discuss the implementation processes and procedures may yield additional, useful information. In conclusion, Nunn and Jantz found that teacher efficacy provides supportive evidence when examining implementation progression. 
Nellis (2012) reviews the notion of school teams and how they can support RTI implementation. Nellis suggests that a clear purpose and goals are the first steps for successful teaming. The lack of a clear purpose and function make team building problematic. Teams need clearly defined procedures and rules, as well as, documentation requirements that can dictate procedure and support implementation. Collaborative efforts by all stakeholders (team members), as well as resources, district support, training and procedures all coalesce to create successful implementation.

Fuchs and Bergeron (2013) state that effective implementation relies on collaborative efforts across a variety of school personnel. The authors had conversations with a classroom teacher, a literacy specialist, and a special educator. As a result of these conversations, they reported that all stakeholders found strength in collaboration across and among peers. However, it was also stated that roles and responsibilities must be clearly defined to ensure success. All three stakeholders indicated the biggest challenges to successful implementation to be scheduling and time. The classroom teacher and the special educator also mentioned staff buy-in as a barrier to implementation. While many factors can effect successful implementation, the fact remains that RTI offers a scaffold, how you build depends on stakeholders.

Dissertation work by Millhouse-Pettis (2011) found survey participants' perceptions of the district RTI implementation plan varied across stakeholders. Millhouse-Pettis also found there were differences in perceptions about how services were to be delivered and by whom. Adams (2013) reported in his dissertation work that teachers were found to have significant differences in perceptions in deference to knowledge or the RTI framework, progress monitoring, ability to implement RTI and professional development. This snapshot provides heretofore unseen suggestions about the status of implementation. 
Murakami-Ramalho and Wilcox (2012) completed a case study of a school principal at the elementary level who was implementing RTI. They lead from the premise that RTI should not focus solely on the student with learning disabilities but also provide intervention services for at-risk students. The authors found that when attempting to improve a low performing school challenges arise and a specific type of leader is needed. The school leader must exhibit skills that include an ability to define the achievement gap, garnering staff buy-in, provide professional development and training, general leadership abilities, and accountability. A skilled leader is an essential component to successful implementation.

Dissertation work by Kimmell (2008) used an interview protocol to gauge implementation of RTI with administrators and teachers in two elementary schools in Los Angeles, California. A total of thirteen people were interviewed with regard to the implementation processes at each school. Kimmel also completed observations, which occurred at the bi-monthly RTI leadership team meeting. The findings Kimmell's study indicated issues that can hamper implementation - teacher buy in, leadership at the school and district level, teacher roles, professional development, and resource allocation. A supplementary finding indicated that although the schools were in the same district, implementation varied.

Werts et al. (2009) completed a study that surveyed only one set of stakeholders, special education directors. The study conducted email surveys to assess RTI implementation in North Carolina. Survey respondents were asked to answer eight multiple choice questions that dealt specifically with RTI practices and two additional open questions that related to the RTI trainings they had attended. Approximately 100 surveys were delivered, with 46 surveys returned and analyzed. The data was analyzed both as percentages of responses to each multiple choice question, and with an examination of the responses to the open questions. The study results 
indicated that there was little agreement on the implementation procedures of RTI. Werts et al. concluded that while there was much concern on the inner workings of RTI and the achievement levels of students, there was a lack of focus on the implementation process.

Hoover et al. (2008) also surveyed directors of special education at state departments of education in all 50 states and in Washington DC. The surveys contained 18 questions both demographic and related to the critical elements of RTI. A return rate of eighty-six percent of (44/51) surveys analyzed, indicated that 41 out of 44 states were implementing RTI in a variety of formats. Implementation of the initiative, although not directly asked, did appear in the free response questions. Findings of the study found that implementation fidelity was widely different across the respondents.

Practice and Current Research. While much has been written on the value of RTI, the implementation procedures followed across the Unites States, as well as, the results of student achievement within the program, little has been studied about the implementation process and its subsequent successes and challenges. Many of the aforementioned sources provided a variety of checklists and survey-like items that assist with determining success (Brown-Chidsey \& Steege, 2005; Mellard \& Johnson, 2008; Wright, 2007). However, only a few resources provided actual checklists to determine implementation status (Hall, 2008; WVDE, 2007). Research on RTI implementation procedures is limited due, in part to, the fact that RTI implementation is in the early stages of being.

\section{School Wide Implementation}

Weishaar and Weishaar (2012) discussed circular causality in the sense that people, events, and systems jointly have an effect on one another. They believed that for change to occur within a school district, involvement from several systems is vital. Three primary systems, which 
included the classroom system, the school building system, and the district-wide system, are crucial to influence change in implementation. Two secondary systems, parental and administrative, were also mentioned as important to this process. The secondary systems will not be discussed here as the surveyed stakeholders fall within the three, primary systems mentioned. The authors agreed that all the systems are interconnected "when the reading achievement of children is involved" (p. 62).

Weishaar and Weishaar (2012) delineated three stages within each of the three systems that should be considered for the success of RTI at the school level. Stage One refers to Consensus Building which involved the areas of "discussion, development of a rationale for implementation, and communication of RTI concepts" (p. 62). Stage Two detailed Building Infrastructure which "involves analysis of current practice, determination of what needs to occur for successful RTI implementation, and filling the gap between current practice and what needs to occur" (p. 62). The third and final stage, Implementation, included "making sure that appropriate structure and supports are in place for successful RTI implementation” (p. 63).

Dissertation work by Monaghan (2011) investigated teacher and administrator perceptions within RTI implementation. Monaghan used interviews, surveys, and primary source documents to complete this study. Within the study, multiple areas of concern arose. Confusion existed with the referral process, responsibility of roles, as well as, a clear plan for implementation was missing. Other issues found in relation to implementation were processes were not monitored and responsibility for implementation duties were not clear. Participants reported that support from the district level was minimal and training and professional development needs had not been met. Monaghan recommends a shared vision is essential for 
implementation success, as well as concise policies, resource allocation, a communication of next steps.

District-level system. This system encompassed the board of education, superintendent, and the remainder of district-level administrators. Weishaar and Weishaar (2012) suggested that at this level, the primary responsibilities involve consensus building and building infrastructure. The idea of consensus and infrastructure building proposes a dialogue and tacit understanding about the most important minutiae of RTI. It is then the responsibility of this system to provide the necessary supports and resources needed for implementation.

In an effort to insure that this implementation was fully functioning and all stakeholders have what is necessary for full implementation, a line of communication must be developed by the district level. At this level, the responsibility for aligning initiatives and programs to the district's goals and mission must be embraced, and these first steps must be initiated by the district administrative stakeholders. This anticipated dialogue should move the implementation process forward in a positive manner. One caution would be recommended in that discussion protocols are set in advance that would allow a free-flowing exchange among and between stakeholders. If this is to work properly and ultimately benefit all children, fear of retaliatory measures must be addressed and deflated. Those at the district level have the culpability to propel this implementation to the next level.

O’Connor and Freeman (2012) offer multiple considerations with regard to RTI implementation and district level considerations. They theorize that RTI implementation demands large-scale system reform at all levels - district, school, and classroom. It is essential to effective implementation that all stakeholders are seen as agents of change. Specific challenges found by O’Connor and Freeman relate to ineffective assessment practices and a lack of 
professional development and training for staff. They also reported that resource allocation serves as an impediment to implementation. They globally define resource allocation in the areas of financial concerns, scheduling/time, and staffing.

Building-level system. Although the building system encompasses all personnel placed in the building, this section addresses the principal, specifically. The responsibility for this level contains both consensus and infrastructure building (Weishaar \& Weishaar, 2012). The principal is charged with supplying information about RTI to the staff and determining the current commitment level within the implementation process.

White, Polly, and Audette (2012) conducted a study on one elementary school's RTI implementation. A majority of study participants articulated that leadership was a key factor in implementation success. While leadership was a derivative of success, time was one of many obstacles to implementation. Participants reported they had many new responsibilities and no current responsibilities were removed. It was also reported that a steep learning curve existed for the roles and procedures required for implementation of RTI. Collaboration time was a barrier to implementation at this school. However, the results of the study recommend the following areas for successful implementation - coordination between school and district level, commitment from the school leader, a focus on procedures, utilization of data, and inclusion of all stakeholders in intervention plans.

As successful implementation requires the effort and capacity of all stakeholders, a lack of support at one level will seriously undermine the entire process. A necessity exists for the school level administration to become immersed in the school RTI culture in an effort to assist teachers with successful implementation. The administrator must look beyond the face value of 
implementation and develop a clear picture of what is taking place and exactly where the classroom level is experiencing difficulty.

Classroom-level system. The classroom level system encompasses those who work directly in the classroom - classroom teachers, reading specialists, and special educators. Boulware-Gooden et al. (2010) found that the perceptions of teachers offered significant insight into the implementation processes and procedures. At the classroom level system, Weishaar and Weishaar (2012) suggested the primary responsibility of this level to be the successful delivery of the "core curriculum, systematic screening of all students, tiered intervention, and regular progress monitoring" (p. 66).

As mentioned across the district level and school level, communication among and across this level appear to be disjointed. Exchange of ideas must be encouraged and all parties must see the complete picture and their involvement as part of the whole. The denigration of one group versus another must come to an end and discourse must occur without fear of reprisal. An understanding must be reached by all stakeholders that this enterprise is designed to create success for students and has no place for personal agendas or ideas that do not support the role of ensuring adequate progress for students.

\section{Summary}

While varying forms of intervention existed in public schools for many years, the reform reauthorization of IDEA and NCLB forced schools to examine the programs used and the results of student learning. The reexamination prompted widespread professional development in the areas of teacher beliefs and perceptions, best practice in teaching reading, responsive teaching, assessment, and collaboration. These reforms prompted the use of RTI as an intervention method that replaced or worked in tandem with the discrepancy model. However, the proposed changes 
created a need to reform, but numerous difficulties arose. With this in mind, the purpose of this study is to determine barriers to the implementation of the RTI initiative, how stakeholders rate their implementation status, as well as, their involvement in the implementation process to inform future implementation processes. 


\section{CHAPTER 3}

\section{METHODOLOGY}

\section{Introduction}

This chapter presents the methodology used in this research. These following sections present the purposed of the study, the participants for the study, and research design with the scope of the study. The next sections describe the instrumentation used to collect the data, the procedure used in data collection and the methods used to analyze the data.

\section{Purpose}

The purpose of this study was to gauge the implementation level of the nationally mandated RTI initiative in West Virginia (WV) in respect to multiple stakeholders in three West Virginia (Research Questions 1 and 2) county school districts. The target group consisted of superintendents and other county level administrators, school administrators, literacy coaches, reading specialists, special education teachers, and classroom teachers. The following areas-

- Assessment,

- Instruction,

- Collaboration and Problem Solving,

- Professional Development, and

- Special Education Referral and Eligibility procedures - were used to assess implementation.

The rural communities of Upton, Rankin, and Prentiss, all of which are affiliated with the Sherman Area Education Agency (RESA), became the site of this research study. 


\section{Participants}

In 1972, an act of the WV Legislature required the WV Board of Education to create multi-county Sherman Area Education Agency (RESA s) to act as supportive entities within the state educational system to assist schools and school systems with educational programming (RESA III, 2010). There are eight RESA s located in WV. The mission of the statewide RESA network was to act "as a collection of separate, nonhierarchical organizational entities established and supported in part by the state to serve as a statewide system for the development, production, and/or delivery of programs and services deemed essential for promoting a common set of needs for the schools and school systems within their respective region" (RESA Mission and Vision, 2009).

RESA, the largest RESA in the state, is comprised of twelve counties, located in North Central WV. These twelve counties house a total of 128 schools ranging from pre-K facilities to secondary education institutions. RESA serves close to 3000 educators in its twelve counties. This research sample with a 29.6 return rate included personnel from elementary and middle schools in three rural counties; Upton, Rankin, and Prentiss were located in North Central WV, representing 32 schools and approximately 733 stakeholders/participants. (See Table 1)

Table 1

Participating County Demographics

\begin{tabular}{|c|c|c|c|c|c|}
\hline County & No. Schools & No. Teachers & $\begin{array}{l}\text { No. Literacy } \\
\text { Coaches }\end{array}$ & $\begin{array}{l}\text { No. of School } \\
\text { Administrators }\end{array}$ & $\begin{array}{c}\text { No. of } \\
\text { County Level } \\
\text { Administration }\end{array}$ \\
\hline Prentiss & 11 & 257 & 1 & 12 & 2 \\
\hline Rankin & 13 & 263 & 4 & 16 & 2 \\
\hline Upton & 8 & 197 & 3 & 11 & 2 \\
\hline Totals & 32 & 717 & 8 & 39 & 6 \\
\hline
\end{tabular}

Note. Number of Teachers includes: Classroom, Special Education, and Reading Specialist. 
Survey participants were those directly involved with the implementation processes and procedures of RTI. The participants in the study were county level administrators (responsible for RTI implementation), principals, literacy coaches, reading specialists, special education teachers, and classroom teachers. The participants listed above were chosen because they were directly responsible in multiple ways for the delivery of RTI.

The three counties, Prentiss, Rankin, and Upton shared similar degree demographics (see Table 2). The counties respectively retained professional staff who possessed a Master's Degree or higher at $61.1 \%, 71.1 \%$, and $67.2 \%$ (West Virginia Education Information System [WVEIS], 2009). This was slightly higher than the state average of $60.7 \%$ (WVEIS). Another area of similarity occurs within the average years of experience of professional staff with 17.7 years, 19.1 years, and 17.4 years (WVEIS). The counties also shared comparable Low Socio-Economic Status (SES) at 55.1\%, 55.3\%, and 55.9\%. Low SES students were identified as those who qualify for free and reduced lunch (WVDE).

Table 2

Degree and Experience Demographics

\begin{tabular}{|c|c|c|c|c|c|c|c|c|c|c|c|}
\hline & $\begin{array}{l}\text { Prof. } \\
\text { Staff } \\
\text { Exp. }\end{array}$ & $\begin{array}{l}\% \text { classes } \\
\text { not taught } \\
\text { by HQ } \\
\text { Teacher }\end{array}$ & $\begin{array}{l}\text { BA/ } \\
\text { BS }\end{array}$ & $\begin{array}{l}\text { BA/ } \\
\text { BS }+15\end{array}$ & $\begin{array}{l}\text { MA/ } \\
\text { MS }\end{array}$ & $\begin{array}{c}\text { MA/ } \\
\text { MS +15 }\end{array}$ & $\begin{array}{l}\text { MA/ } \\
\text { MS } \\
+30\end{array}$ & $\begin{array}{c}\text { MA/ } \\
\text { MS +45 }\end{array}$ & $\begin{array}{l}\mathrm{PhD} / \\
\mathrm{EdD}\end{array}$ & Other & $\begin{array}{l}\text { Teacher } \\
\text { Permit }\end{array}$ \\
\hline Prentiss & 17.7 & 14.7 & 12.8 & 25.4 & 12.1 & 9.0 & 13.3 & 25.8 & 0.9 & 0.7 & 6.7 \\
\hline Rankin & 19.1 & 4.3 & 12.2 & 16.3 & 5.6 & 12.2 & 17.6 & 35.4 & 0.8 & 0.0 & 2.4 \\
\hline Upton & 17.4 & 3.5 & 11.5 & 21.3 & 7.7 & 11.8 & 16.6 & 30.2 & 0.9 & 0.0 & 3.7 \\
\hline
\end{tabular}

Note. Professional Staff Experience is represented in years; all other data is percentage. $\mathrm{HQ}=$ Highly Qualified. 


\section{Research Design}

This study used survey research methodology (Trochim, 2006). Some advantages to using a survey method include the ability for a single researcher to collect from a myriad of participants, all participants receive the same questions, and the question structures can be more complex (Bernard, 2006). Some disadvantages of survey data are realized in its potential to be skewed as respondents may provide answers they believed the researcher wanted to see, questions could occur that cannot be answered, and the intended recipient may not be who answered the survey questions (Bernard, 2006). Fowler postulated that within the realm of survey research there was not an exact method for use at all times, therefore, he suggested that the researcher use the method or methods that mesh best with the needs of the current research. All participants were given the opportunity to contact the researcher for an interview; none agreed to participate.

\section{Context: Implementation in West Virginia}

As part of the WV RTI Initiative, the West Virginia Department of Education (WVDE) established An Implementation and Technical Assistance Guide for Districts and Schools, that provides a readiness checklist and implementation forms (Palenchar, Brown, \& Jennings, 2006). Additionally, the guide proposes three phases for establishing RTI throughout the state. Phase I was the initial phase of implementation, Phase II expanded the program to all elementary schools, as well as, implementation in middle schools, and Phase III will be direct expansion to high schools. This section details the phases for implementation of RTI and clarifies participants.

Phase I took place between 2005 and 2007 and was establishing pilot schools, developing the implementation guide, implementing timelines in WV policy, funding, and the creating of a department and collaborative to assist with expansion. Phase II (2007-2010), incorporated 
inclusion in all elementary schools, determines implementation in middle and high schools, develops communication at all levels, creates a document repository for middle and high schools, provides funding, designs monitoring and professional development support at the state level, assesses resource capacity for elementary and middle schools, and establishes and implementations evaluation. Phase III (2010-2012) was to be direct expansion to high schools, an updated document/resource repository, continued communication, and assessment and evaluation (WVDE, 2007). Phase III, under a new moniker - Support for Personalized Learning (SPL), is currently ongoing, but not fully implemented at the secondary level.

As a result of Phase II, the WVDE created a new position, the RTI Specialist, in September 2009. This position was an extension of the Office of Special Programs, Extended and Early learning, but was located in each region. The duties for this position included, but were not limited to, providing professional development on RTI, examining the implementation level of each school, and assisting schools with implementation and analysis of the RTI programs that were in place. Currently, this position has been discontinued, however; each RESA has new positions that assist with intervention.

\section{Instrumentation: Survey}

The design of the survey was intended to yield numerical data about a particular populace (Fowler, 2009). WV does not currently possess an RTI implementation survey to monitor RTI implementation, the survey instrument was designed explicitly for the purpose of this research study. As part of the RTI initiative in the state of WV, the Department of Education Office of Special Programs has created several documents that provide assistance with assessing the implementation of RTI at the state level: the survey (Appendix B), the RTI Implementation Checklist (see Appendix C) and the District Level RTI Implementation Status Rubric (see 
Appendix D). The survey was designed using the documents mentioned previously, as well as, the Six Guiding Principles of Response to Intervention (2010) set forth by the International Reading Association as well as the Response to Intervention Process: Implementation Status Report at Elementary Level (2008, Appendix F). The researcher used the six guiding principles:

- Instruction

- Responsive Teaching

- Assessment

- Collaboration

- Systemic and Comprehensive Approaches, and

- Expertise

as headings and separated the information from the WVDE School Readiness for Response to Intervention: A Self-Assessment and the Response to Intervention Process: Implementation Status Report at Elementary Level as the topics fit into each category to create a portion of the survey. The survey also contained information related to RTI implementation and demographic information as it related to implementation.

The protocol for this survey was a self-report survey of 22 items separated into three sections. Section I contained five, self-report questions, which focused on stakeholders responsible for implementation delivery, materials used for each Tier, as well as, programs used for assessment and the amount of time spent daily on RTI. Self-report questions allowed the respondents to answer in their own words, which allowed for unforeseen responses that the researcher had not anticipated (Fink, 2003; Fowler, 2009).

Section II was composed of nine questions. Six of the questions contained 36 Likert-like items and were organized using six headings which were endorsed as best practice by IRA's RTI 
Commission on RTI (2010): Instruction, Responsive Teaching and Differentiation, Assessment, Collaboration, Systemic and Comprehensive Approaches and Expertise were designed to provide specific information from each stakeholder related to implementation. A Likert-scale allows respondents to answer with "varying degrees of intensity on a scale ranging between extremes such as agree-disagree, like-dislike, or accept-reject" (Isaac \& Michael, 1997, p. 148). The three remaining questions were self-report questions that allowed the respondent to comment on components that have delayed RTI implementation, the time frame and procedures for implementation at each tier, and the opportunity to add any additional, noteworthy information about RTI implementation.

Section III contained eight questions that requested a variety of demographic information from participants which included current position, level predominantly taught, years of experience, degree level, conferring institution, certification level and area, age, and the current county of employment. A final statement on the survey invited participants to contact the researcher for participation in an interview.

\section{Validity and Reliability}

"A reliable survey instrument is consistent; a valid one is accurate" (Fink, 2003, p. 47). Fink states that content validity refers to the degree an instrument can completely and properly assess the intended content. Reliability was assessed using content validity. Specific measures were enacted to ensure validity and reliability of the survey instrument. In order to accommodate a field test, a panel of RTI specialists (see Appendix G) from the RESAs across the state, as well as the WVDE coordinator of Research and Evaluation field tested the items in late August 2010. The survey was delivered via email, and each respondent was asked to take the survey in its original form. A panel of RTI specialists was then asked to make notations on the document that 
would allow for future discussion, as well as any suggestions for additional self-report questions. The expert panel responded to the researcher via email with comments and suggestions regarding the survey instrument. Subsequently, modifications were made to the survey instrument as needed and then returned to the panel for an additional reading in early September. Any additional comments and suggestions were then added and surveys were distributed in September 2010. A further measure used to determine content validity was Dillman's (1978) content validity questions. The questions ask the test group to check for easily understood vocabulary, vague questions, and researcher assumptions.

\section{Data Collection: Timeline and Procedure}

Data collection occurred over a twelve week period in September/October/November 2010. Round One announcements were disseminated to administrators through email addresses provided by RESA. I requested that building level administrators forward the email to all building level teachers (classroom, special education, Title I). The email stated that all teachers, principals, and county level administrators had the opportunity to participate in a survey regarding the implementation of RTI in RESA. The initial message detailed for participants the design of the study, as well as, the purpose behind the research. A support document from the RESA Executive Director (Appendix H, RESA letter), accompanied the above email encouraging participation in the survey. The support document stated that RESA is aware of the research and was supporting the doctoral student in the endeavor. However, no penalty or repercussion existed for not responding. This method of connecting the research with "a known organization that has legitimacy" can be found in the work of Dillman (2006).

This survey was administered using SurveyMonkey.com, an Internet-based survey engine that allows for anonymity of respondents. An Internet survey was chosen due to the fact that with 
this method the cost of collection is minimal, as well as, there is a "potential for high speed of return" (Fowler, 2009, p. 83). Fowler stated that this method of survey allows respondents to "provide thoughtful answers" (p. 83). The SurveyMonkey site has two features that allow for anonymity, i.e., "web link collector" and "email invitation” (Survey Monkey Answers and FAQ). Both of these features track respondents and non-respondents, but do so without connecting the response to an actual email address.

As initial response was low, I distributed survey information in the form of paper announcements. I received permission from the county superintendents to provide notices to be placed in school mailboxes at each county office. The paper requests for participation offered the same information that was provided in the initial email. Two reminder notices were also sent in two and four week intervals.

\section{Data Analysis}

Miles and Huberman (1994) discuss data analysis in three distinct ways. The first, data reduction deals directly with the "process of selecting, focusing, simplifying, abstracting, and transforming the 'raw' data" (p. 22). Secondly, data display is "an organized assembly of information that permits conclusion drawing and action taking" (p. 22). Lastly, a process of conclusion drawing and verification takes place.

Data in this study was analyzed using both inferential and descriptive statistics. Statistical data from surveymonkey.com was delivered as a tally record, filtered by variables, downloaded into a Portable Document Format (PDF), an Excel spreadsheet, or into specific statistical software programs. The Statistical Package for the Social Sciences (SPSS), Version 19, was used to analyze all quantitative data. The Likert-scale results which focused on the six implementation categories from Research Questions (RQ) one and two were reported as 
frequency distribution. Gravetter and Wallnau (2007) stated that frequency distribution allowed the researcher to take a chaotic set of data and organize them by the number of respondents represented in each category. This allowed for a clear picture of where stakeholders rated their implementation. In an effort to provide concise results, all Likert-like item responses were classified as either established or not established for the purposes of analysis.

Table 3 demonstrates the relationship between the four guiding questions used in the study and of this survey protocol, as well as, the IRA Guiding Principles for Response to Intervention (2010). Research question one, focusing on the level of involvement of stakeholders within implementation processes, was addressed through Survey Protocol (SP) questions one, five, and six and questions 10-16. Research question two, focusing on the stakeholder rating of school implementation status, was addressed through SP questions two through six, eight, and questions 10-16. Research question three, focusing on perceptions of stakeholders with regard to their current position, was addressed through SP questions one, six, and seven and questions 1016. Research question four, focusing on components that have delayed implementation, was addressed through question twelve. 
Table 3

Survey Instrument and Research Question Analysis

\begin{tabular}{|c|c|c|c|c|c|}
\hline & $\begin{array}{c}(\mathrm{SP}) \\
\text { Demographic } \\
\text { Information }\end{array}$ & $\begin{array}{c}(\mathrm{SP}) \\
\text { School Level } \\
\text { Implementation }\end{array}$ & $\begin{array}{c}(\mathrm{SP}) \\
\text { County Level } \\
\text { Implementation }\end{array}$ & $\begin{array}{c}\text { (SP) } \\
\text { Open } \\
\text { Questions }\end{array}$ & $\begin{array}{c}\text { (SP) } \\
\text { IRA } \\
\text { Guiding } \\
\text { Principles }\end{array}$ \\
\hline $\begin{array}{l}\text { Research } \\
\text { Question 1 } \\
n=17\end{array}$ & $15-22$ & $\begin{array}{c}\text { 6d; 7bef; } \\
\text { 8adef; 9fgh; } \\
\text { 10efg; 11cde }\end{array}$ & $\begin{array}{c}\text { 6d; 7bef; } \\
\text { 8adef; 9fgh; } \\
\text { 10efg; 11cde }\end{array}$ & & \\
\hline $\begin{array}{l}\text { Research } \\
\text { Question } 2 \\
n=22\end{array}$ & $15-22$ & $\begin{array}{c}\text { 6abc; 7abcd; } \\
\text { 8abcd; } \\
\text { 9abcde; } \\
\text { 10abcd; } \\
11 \mathrm{ab}\end{array}$ & $\begin{array}{l}\text { 6abc; 7abcd; } \\
\text { 8abcd; } \\
\text { 9abcde; } \\
\text { 10abcd; } \\
11 \mathrm{ab}\end{array}$ & & \\
\hline $\begin{array}{l}\text { Research } \\
\text { Question } 3\end{array}$ & $15-22$ & 6-11 & 6-11 & & \\
\hline $\begin{array}{l}\text { Research } \\
\text { Question } 4\end{array}$ & & & & 12 & 12 \\
\hline
\end{tabular}

Note. IRA Guiding Principles include (1-6). *SP survey protocol. See Appendix B for Survey.

Research question three focused on perception and stakeholder role, and was analyzed with Analysis of Variance (ANOVA) to test the differences "between the means of more than two groups on one factor or dimension" (Salkind, 2004, p. 197). This form of analysis allowed for variance that existed both between and within groups (Salkind, 2004). This question answered whether there was a difference in responses across the groups of stakeholders depending on their job placement. In essence, the independent variable was the position held by the respondent and the dependent variable was each stakeholder's rating of implementation. After analysis, a Post Hoc test was completed if variance was found to be at a significant level $(>.05)$.

Research question four focused on implementation barriers, and was analyzed qualitatively. Respondents were asked to respond to an open question relative to components that created barriers to the implementation process. Responses were coded using predetermined a priori codes, people and policy/procedures, as well as, with emerging codes as they appeared. 
The a priori codes were established from the implementation work of Fixsen et al. (2005). Fixsen et al. referred to the core components of implementation as "...to the most essential and indispensable components of an implementation practice or program" (p. 24). These included "staff selection, pre-service and in-service training, ongoing consultation and coaching, staff and program evaluation, facilitative administrative support and systems interventions" (Fixsen et al., p. 28).

Denzin and Lincoln (2000) stated "triangulation has been generally considered a process of using multiple perceptions to clarify meaning...but also served to clarify meaning by identifying different ways the phenomenon is seen" (pp. 443-444). Patton (2002) stated the use of triangulation can fortify a study with a combination of both qualitative and quantitative methods. Merriam (2002) added that triangulation can be utilized to strengthen validity. The first source of triangulation occurred with the use of investigator triangulation which requires additional evaluators (Merriam, 2002; Patton, 2002). The investigators were teachers and/or principals who are familiar with the field of education. Two investigators were asked to read the transcribed documents for the open survey question, and code them for the six IRA RTI Commission Guiding Principles, as well as, create coding for emerging codes. The researcher discussed the procedure with the investigators and answered any questions or concerns. Interrater reliability determined whether uniformity occurs with the raters. Inter-rater reliability was established at a level of $90 \%$ agreement. Salkind (2004) offered this sentiment with regard to inter-rater reliability that "the more similar the ratings are, the higher the level of inter-rater agreement and inter-rater reliability" (p. 286). The investigators were asked to follow the researcher's procedure from above. Two investigators, both familiar with Response to Intervention, read and coded transcripts. Lincoln and Guba (1985) stated that these evaluators 
should encompass the following criteria "methodological sophistication, minimal knowledge about the subject of the study, integrity, and experience with analyzing” (p. 379). Appendix G provides a detailed listing of the investigators' backgrounds.

\section{Summary}

“The current national trend in today's schools is to meet the needs of struggling and atrisk learners through the implementation of multi-tiered response to intervention models." (Hoover, Baca, Wexler-Love, \& Saenz, 2008, p. 1). While this implementation has been in process since the reauthorization of the IDEA in 2004, little research exists on the implementation process. While Werts, Lambert, and Carpenter (2009), and Hoover et al. (2008) have both discussed implementation procedures in their separate studies, their research surveyed only special education directors. This research neglects the many other stakeholders within the RTI implementation process. This omission sets the stage for the current study and contributes to the current research on RTI implementation. This study will potentially yield multi-faceted results that have the potential to impact RTI implementation procedures for multiple stakeholders.

As analysis began, it became clear that essential the question was whether the county was established or not established in the processes and procedures of implementation. In order to analyze the results, all responses were placed into two categories - Established or Not Established. Therefore, responses in the Likert categories of Not in Place, Emerging, and Making Progress were merged to form the 'Not' designation, while those marked as Established remained in that category. 


\section{CHAPTER 4}

\section{RESULTS OF THE STUDY}

\section{Introduction}

This study explored stakeholder perceptions of RTI implementation within three school districts in Central West Virginia. Chapter Four contains an explanation and analysis of the data collected from the RTI survey and offers data and key findings which relate directly to the research questions and concludes with a summation of the findings.

The following questions guided this study:

1. To what extent are stakeholders (district level administrators, principals, classroom teachers, reading specialists, and special educators) involved in the implementation process as per the RTI Implementation Checklist developed by the WVDE?

2. To what extent do stakeholders rate their implementation status:

a. (Not in Place, Emerging, Making Progress, Established) as defined by the District Level RTI Implementation Status Rubric developed by the WVDE in the areas of
a. assessment;
b. instruction;
c. collaboration and problem solving;
d. professional development;
e. Special Education Referral and Eligibility Procedure?

3. In what ways do the perceptions of stakeholders (superintendents/other district personnel, coaches, principals, classroom teachers, reading specialists) differ as a result of the position they hold? 
4. What components (e.g., school, district, state leadership; professional development; data analysis; resources; funding) have either assisted or delayed the implementation of RTI?

\section{Major Findings}

The survey contained 22 questions included in three sections. Section I contained five questions related to who delivers intervention as well as the programs used to deliver. Section II contained nine questions, six of which were comprised of 36 items and three free response questions with respect to the following six categories:

- Instruction,

- Responsive Teaching and Differentiation,

- Assessment,

- Collaboration,

- Systemic and Comprehensive Approaches, and

- Expertise.

Section III contained eight questions with connected to demographics and position.

SPSS 19 was used to calculate frequencies, means, and standard deviations for each of the 22 statements found in Section II of the survey that related to research question one. The frequencies were categorized into 3 areas that included

- Highly established: rated at a rate of $51 \%$ or higher by all stakeholders or a majority of stakeholders;

- Moderately established: rated at a rate $51 \%$ or higher by some stakeholders;

- Not established: rated at a rate of $50 \%$ or lower by all stakeholders. 
Research question one: Implementation status. Section II of the survey called for participants to rate the RTI implementation status for their school or county regarding the following:

assessment, instruction, collaboration, and problem solving, professional development, and Special Education referral and Eligibility Procedures.

A Likert scale called for ranking items from one to four, where 1 = "Not in Place," $2=$ "Emerging," 3 = "Making Progress," and 4 = "Established." An example statement requested survey participants to rank items such as "Tier I instruction includes differentiated, small group work."

Highly established. As a result of this division, seven of the twenty two survey items $(6 a b, 7 a b, 8 a d, 10 a)$ were pertinent to this research and presented a $51 \%$ or higher established rating by all stakeholders. These seven items related to the beginning guidelines and initiatives related to RTI implementation in West Virginia (WV) (Palenchar et al., 2006). Based on survey results, several of these items related directly to issues of instruction (Table 4). A majority of stakeholders reported that Tier I instruction included small group work (6a), Tier II provided 30 minutes of instruction beyond the scheduled Reading Block (6b), and the Master schedule met WV policy requirements with regard to required minutes for each subject area $(7 a)$. Stakeholders also reported that intervention time blocks were clearly designated in the school schedule (7b) and training on delivery of core reading program (10a) had been provided. The two additional items deemed highly established with stakeholders dealt primarily with assessment systems. 
Stakeholders agreed that universal screening was provided three times yearly $(8 a)$ and a data system was in place $(8 d)$ that included both progress monitoring and benchmarking, as well as, a schedule for delivery and completion of these assessments (Table 4).

Table 4

Survey Items: Highly Established by All Stakeholders

\begin{tabular}{|c|c|c|c|c|c|}
\hline & Position & Established & $\begin{array}{l}\text { Making } \\
\text { Progress } \\
\end{array}$ & Emerging & Not In Place \\
\hline & & $\underline{\%}$ & $\underline{\%}$ & $\underline{\%}$ & $\underline{\%}$ \\
\hline 6a.Tier I instruction includes & CT & 73.2 & 17 & 7.1 & 2.7 \\
\hline differentiated, small group work. & RS & 80 & 20 & 0 & 0 \\
\hline & SP & 54.3 & 40 & 5.7 & \\
\hline & $\mathbf{P}$ & 80 & 13.3 & 6.7 & 0 \\
\hline & CA & 80 & 20 & 0 & 0 \\
\hline 6b. Tier II intervention is provided & CT & 76.1 & 15.9 & 3.5 & 4.4 \\
\hline for 30 minutes daily beyond the & RS & 95.2 & 4.8 & 0 & 0 \\
\hline required Reading block & SP & 70.6 & 26.5 & 0 & 2.9 \\
\hline & $\mathbf{P}$ & 86.7 & 13.3 & 0 & 0 \\
\hline & CA & 100 & 0 & 0 & 0 \\
\hline$\cong 7 \mathrm{a}$. The master schedule includes & CT & 86.6 & 7.1 & 3.6 & 2.7 \\
\hline Policy 2510 time requirements for & RS & 95 & 5 & 0 & 0 \\
\hline Reading/Language Arts & SP & 80 & 14.3 & 2.9 & 2.9 \\
\hline Ex & $\mathbf{P}$ & 100 & 0 & 0 & 0 \\
\hline & CA & 100 & 0 & 0 & 0 \\
\hline 7b. Intervention blocks are clearly & CT & 78.6 & 11.6 & 4.5 & 5.4 \\
\hline designated in the master school & RS & 81 & 14.3 & 0 & 4.8 \\
\hline schedule. & SP & 67.6 & 29.4 & 0 & 2.9 \\
\hline & $\mathbf{P}$ & 93.3 & 6.7 & 0 & 0 \\
\hline & CA & 80 & 20 & 0 & 0 \\
\hline 10a. Teachers are trained on how to & CT & 62.6 & 22.4 & 5.6 & 9.3 \\
\hline deliver the core reading program & RS & 85 & 10 & 5 & 0 \\
\hline with fidelity & SP & 61.1 & 33.3 & 2.8 & 2.8 \\
\hline & $\mathbf{P}$ & 73.3 & 26.7 & 0 & 0 \\
\hline & CA & 100 & 0 & 0 & 0 \\
\hline 8a. Universal screening occurs 3 &  & 78.6 & $\overline{77.8}$ & $\overline{77.8}$ & $\overline{77.8}$ \\
\hline times a year. & RS & 100 & 0 & 0 & 0 \\
\hline & SP & 85.3 & 8.8 & 2.9 & 2.9 \\
\hline $\bar{z}$ & $\mathbf{P}$ & 80 & 13.3 & 6.7 & 0 \\
\hline$=$ & CA & 100 & 0 & 0 & 0 \\
\hline $8 \mathrm{~d}$. Our school has a data system in & CT & 69.1 & 15.5 & 6.4 & 9.1 \\
\hline place for both progress monitoring & RS & 75 & 20 & 5 & 0 \\
\hline and benchmark assessments. & SP & 64.7 & 26.5 & 5.9 & 2.9 \\
\hline & $\mathbf{P}$ & 66.7 & 13.3 & 20 & 0 \\
\hline & CA & 60 & 20 & 20 & 0 \\
\hline
\end{tabular}

Note. In this and subsequent tables, $\mathbf{C T}$ will indicate Classroom teachers, $\mathbf{R S}=$ Reading

Specialists, $\mathbf{S P}=$ Special Educators, $\mathbf{P}=$ Principals, and $\mathbf{C A}=$ County Level Administrators. 
Moderately established. Thirteen of the 22 survey items $(6 c, 7 c d, 8 b c, 9 b c d, 10 b c d$, $11 a b$ ) demonstrated a mixed pattern of ratings (Table 5), with some stakeholders on each item assigning an established rating at $51 \%$ or higher. As evidenced by the survey, the categories of specific assigned minutes for Tier III (6c), as well as, group sizes for Tier II (7c) and Tier III (7d) were found to be moderately established. The survey item related to specific assigned minutes for Tier III (6c) denoted an established ranking of 51\% or higher by Reading specialists, Special Educators and principals; while the remaining stakeholders ranked the item at $50 \%$ or less. On the items related to group size in Tier II (7d) and Tier III (7c), classroom teachers and principals, respectively, ranked these established at $51 \%$ or higher, while all other stakeholders found the established level below $51 \%$.

In the areas linked to Assessment in relationship to progress monitoring (8b) that occurs as scheduled and the need for additional regularly conducted diagnostic testing (8c), these items consistently ranked below $51 \%$ established by classroom teachers and Special Educators, whereas principals and reading specialists rated these items as established at $51 \%$ or better in each instance. Survey items which address Collaboration and Problem Solving returned mixed ratings from all stakeholders. When discussing shared responsibility among teachers and other interventionists $(9 b)$, special education referral $(9 c)$, and team decision making $(9 d)$, these survey items, without exception, rated highly established at $51 \%$ or greater by principals and reading specialists. Classroom teachers also rated these items moderately established at $51 \%$ or higher. However, county level administration and special educators consistently ranked these items to be less than $51 \%$ established.

The survey items that link specifically to aspects of Professional Development included training offered in data analysis $(10 b)$, training provided in research-based intervention programs 
(10c), as well as, job-embedded professional development $(10 d)$, provided mixed results with respect to established practices. While some stakeholders rated these items highly established at $51 \%$ or higher, a pattern for ratings could not be determined within this group of items because a consistency of rankings did not exist. Reading specialists, principals, and county level administrators ranked two of the items as highly established; however, classroom teachers and special educators ranked at least two of the items as moderately established. The last items in the mixed rating category, related specifically to Special Education Referral and Eligibility Procedures. These survey items included data collection requirements $(11 a)$ and training provided for the school psychologist in RTI $(11 b)$. These items include data collection required for special education referral, multi-disciplinary evaluations, as well as, determining eligibility based on RTI procedures. The ratings for these items were found to be highly established by both principals and county level administrators. However, all other stakeholders found this area to be less than $51 \%$ established (Table 5). 
Table 5

Survey Items: Moderately Established

\begin{tabular}{|c|c|c|c|c|c|c|}
\hline & & Position & Established & $\begin{array}{l}\text { Making } \\
\text { Progress }\end{array}$ & Emerging & Not In Place \\
\hline & & & $\underline{\%}$ & $\%$ & $\underline{\%}$ & $\underline{\%}$ \\
\hline \multirow{15}{*}{ :气气 } & \multirow{5}{*}{$\begin{array}{l}\text { 6c.Tier III is provided for } 45-60 \text { minutes daily beyond the } \\
\text { required Reading block and utilizes a research-based } \\
\text { reading intervention program. }\end{array}$} & CT & $43.5^{*}$ & 26.9 & 13 & 16.6 \\
\hline & & RS & 65 & 30 & 0 & 5 \\
\hline & & SP & 53.1 & 28.1 & 3.1 & 15.6 \\
\hline & & $P$ & 66.7 & 20 & 6.7 & 6.7 \\
\hline & & CA & $20 *$ & 60 & 20 & 0 \\
\hline & \multirow{5}{*}{$\begin{array}{l}\text { 7c. Tier II intervention group size is } 3-5 \text { students per } \\
\text { interventionist. }\end{array}$} & CT & 54.1 & 18 & 6.3 & 21.6 \\
\hline & & $\mathrm{RS}$ & $42.9 *$ & 38.1 & 4.8 & 14.3 \\
\hline & & SP & $41.2 *$ & 29.4 & 14.7 & 14.7 \\
\hline & & $\mathrm{P}$ & $50^{*}$ & 21.4 & 14.3 & 14.3 \\
\hline & & CA & $40^{*}$ & 40 & 20 & 0 \\
\hline & \multirow{5}{*}{$\begin{array}{l}\text { 7d. Tier III intervention group size is } 1-3 \text { students per } \\
\text { interventionist. }\end{array}$} & CT & 36.8* & 24.5 & 8.5 & 30.2 \\
\hline & & RS & 33.3* & 42.9 & 6.1 & 27.3 \\
\hline & & SP & 36.4* & 30.3 & 6.1 & 27.3 \\
\hline & & $\mathrm{P}$ & 61.5 & 15.4 & 0 & 23.1 \\
\hline & & CA & $40 *$ & 40 & 20 & 0 \\
\hline \multirow{10}{*}{ 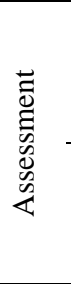 } & \multirow{5}{*}{$\begin{array}{l}\text { 8b. Progress monitoring takes place at least every two } \\
\text { weeks. }\end{array}$} & $\begin{array}{l}\text { CT } \\
\end{array}$ & $\begin{array}{l}50.5 \\
\end{array}$ & $\begin{array}{l}29.0 \\
\end{array}$ & $\begin{array}{c}6.5 \\
\end{array}$ & 14 \\
\hline & & RS & 55 & 35 & 10 & 0 \\
\hline & & SP & $45.5^{*}$ & 42.4 & 6.1 & 6.1 \\
\hline & & $\mathrm{P}$ & 64.3 & 7.1 & 28.6 & 0 \\
\hline & & CA & $40^{*}$ & 40 & 20 & 0 \\
\hline & \multirow{5}{*}{$\begin{array}{l}\text { 8c. Diagnostic testing is conducted regularly to pinpoint } \\
\text { specific skill deficiencies. }\end{array}$} & CT & 52.3 & 24.3 & 15 & 8.4 \\
\hline & & RS & 65 & 20 & 10 & 5 \\
\hline & & SP & 57.6 & 30.3 & 6.1 & 6.1 \\
\hline & & $\mathrm{P}$ & 57.1 & 14.3 & 28.6 & 0 \\
\hline & & $\mathrm{CA}$ & $20 *$ & 40 & 40 & 0 \\
\hline \multirow{15}{*}{ 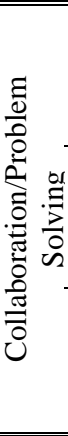 } & \multirow{5}{*}{$\begin{array}{l}\text { 9b. General education teachers, Title I teachers, Special } \\
\text { Educators, LEP teachers and other interventionists share } \\
\text { responsibilities for instruction and intervention. }\end{array}$} &  & 46.4* & 27.7 & 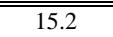 & \begin{tabular}{|c|}
10.7 \\
\end{tabular} \\
\hline & & RS & 60 & 25 & 5 & 10 \\
\hline & & SP & $\mathbf{5 0}^{*}$ & 41.2 & 5.9 & 2.9 \\
\hline & & $\mathrm{P}$ & 73.3 & 20 & 6.7 & 0 \\
\hline & & CA & $20^{*}$ & 80 & 20 & 0 \\
\hline & \multirow{5}{*}{$\begin{array}{l}\text { 9c. Staff focuses on problem solving and adjusting } \\
\text { instruction rather than simply referring students to special } \\
\text { education. }\end{array}$} & $\mathrm{CT}$ & 57.7 & 29.7 & 9 & 6.3 \\
\hline & & RS & 65 & 30 & 5 & 0 \\
\hline & & SP & 41.2* & 44.1 & 8.8 & 5.9 \\
\hline & & $\mathrm{P}$ & 66.7 & 33.3 & 0 & 0 \\
\hline & & CA & $40 *$ & 60 & 0 & 0 \\
\hline & \multirow{5}{*}{$\begin{array}{l}\text { 9d. Instruction and Intervention Teams or Student } \\
\text { Assistance Teams (SATs) work to make decisions such as } \\
\text { movement among tiers, need for additional resources, and } \\
\text { referral to SAT. }\end{array}$} & CT & 53.2 & 27 & 13.5 & 6.3 \\
\hline & & RS & 57.1 & 33.3 & 4.8 & 4.8 \\
\hline & & SP & 37.1* & 42.9 & 14.3 & 5.7 \\
\hline & & $P$ & 66.7 & 26.7 & 6.7 & 0 \\
\hline & & $\mathrm{CA}$ & $50^{*}$ & 50 & 0 & 0 \\
\hline \multirow{15}{*}{ 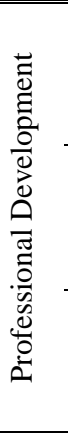 } & & 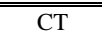 &  & 29.2 & 11.5 & 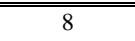 \\
\hline & decision-making & RS & 60 & 25 & 10 & 5 \\
\hline & & SP & 38.9* & 50 & 11.1 & 0 \\
\hline & & $\mathrm{P}$ & 60 & 40 & 0 & 0 \\
\hline & & $\mathrm{CA}$ & 75 & 25 & 0 & 0 \\
\hline & 10c. Teachers are trained on explicit, systematic & CT & 38.9* & 36.1 & 14.8 & 10.2 \\
\hline & intervention planning and delivery including, as & RS & 47.6* & 28.6 & 9.5 & 14.3 \\
\hline & & SP & 28.6* & 54.3 & 8.6 & 8.6 \\
\hline & appropriate, research-based reading intervention & $\mathrm{P}$ & 40 * & 33.3 & 26.7 & 0 \\
\hline & programs. & $\mathrm{CA}$ & 75 & 25 & 0 & 0 \\
\hline & 10d. School-level professional development includes job- & CT & 44.1* & 28.8 & 17.1 & 9.9 \\
\hline & embedded components such as professional learning & RS & 60 & 20 & 10 & 10 \\
\hline & & SP & 37.1* & 45.7 & 11.4 & 5.7 \\
\hline & communities and/or instructional coaching. & $\mathrm{P}$ & 80 & 13.3 & 6.7 & 0 \\
\hline & & $\mathrm{CA}$ & 50 * & 50 & 0 & 0 \\
\hline & 11a. School Assistance Team (SATs) understands RTI & $\overline{\mathrm{CT}}$ & 42.7* & 38.2 & 10 & 9.1 \\
\hline & data collection requirements for special education & RS & $45^{*}$ & 35 & 20 & 0 \\
\hline$=$ & data collection requirements for special education & SP & 28.6* & 45.7 & 22.9 & 2.9 \\
\hline 吾 & referrals. & $\mathrm{P}$ & 64.3 & 21.4 & 14.3 & 0 \\
\hline 踣. & & CA & 75 & 25 & 0 & 0 \\
\hline 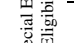 & 11b. The school psychologist is trained in RTI procedures & $\mathrm{CT}$ & 47.8* & 25.4 & 3 & 23.9 \\
\hline & for designing multi-disciplinary evaluations. & RS & $50 *$ & 10 & 10 & 30 \\
\hline 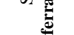 & & SP & 50* & 26.9 & 23.1 & 0 \\
\hline$\dddot{\check{\nu}}$ & & $\mathrm{P}$ & 60 & 30 & 0 & 10 \\
\hline & & $\mathrm{CA}$ & 66.7 & 33.3 & 0 & 0 \\
\hline
\end{tabular}

Note. Items marked with an * indicate a rating of $50 \%$ or below. 
Not established. The final two survey items, concerning Collaboration and Problem Solving and Special Education Referral Eligibility Procedures were rated as not established by all stakeholders. These survey items primarily pertained to common planning time with gradelevel teams $(9 a)$ and Eligibility Committees and the decision making process as it related to Special Education referrals (9e) (Table 6).

Table 6

Survey Items: Not Established by All Stakeholders

\begin{tabular}{|c|c|c|c|c|c|c|}
\hline & & Position & Established & $\begin{array}{l}\text { Making } \\
\text { Progress }\end{array}$ & Emerging & Not In Place \\
\hline & & & $\%$ & $\%$ & $\%$ & $\%$ \\
\hline \multirow{5}{*}{ 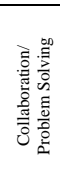 } & \multirow{5}{*}{$\begin{array}{l}\text { 9a. Grade Level teams have } \\
\text { common and adequate planning } \\
\text { times for data analysis and problem } \\
\text { solving. }\end{array}$} & $\mathrm{CT}$ & 31.4* & $2 \overline{8.6}$ & $1 \overline{6.2}$ & $2 \overline{3.8}$ \\
\hline & & RS & $35 *$ & 40 & 10 & 15 \\
\hline & & SP & $29 *$ & 45.2 & 3.2 & 22.6 \\
\hline & & $P$ & 50* & 16.7 & 16.7 & 16.7 \\
\hline & & CA & $40 *$ & 40 & 20 & 0 \\
\hline \multirow{5}{*}{  } & \multirow{5}{*}{$\begin{array}{l}\text { 9e. Eligibility Committees (ECs) } \\
\text { are trained in making eligibility } \\
\text { decisions using RTI procedures for } \\
\text { identification of students with } \\
\text { specific learning disabilities }\end{array}$} & CT & 34* & 27.4 & \begin{tabular}{l|l}
19.8 \\
\end{tabular} & $\begin{array}{l}18.9 \\
\end{array}$ \\
\hline & & RS & $26.3 *$ & 26.3 & 15.8 & 31.6 \\
\hline & & SP & $20 *$ & 40 & 28.6 & 11.4 \\
\hline & & $\mathrm{P}$ & $42.9 *$ & 42.9 & 14.3 & 0 \\
\hline & & CA & $25 *$ & 75 & 0 & 0 \\
\hline
\end{tabular}

Note. Items marked with an * indicate a rating of $50 \%$ or below.

Survey participants ranked the listed survey items in Section II with mixed results with regard to established practices within the implementation processes and procedures of RTI. Principals and reading specialist frequently used Established ratings, while classroom teachers, special educators and county level administrators ranked many of the survey items below $51 \%$ Established. Areas related specifically to common planning times, as well as, special education referral had the lowest rankings from all stakeholders. 


\section{Research question two: Stakeholder involvement in the implementation process.}

Stakeholder involvement within the implementation process was addressed with research question two. Survey participants were asked to rank the school or county implementation status as Not in Place, Emerging, Making Progress, or Established.

To answer research question two, stakeholders rated their perceptions of implementation as it pertained to their position within the home school or county. This research question answered 17 of the 36 of the Likert items. SPSS 19 calculated frequencies, means, and standard deviations for each of the statements; and arranged the statements into three categories centering on the percentage of rankings at the Established level; and then sorted by the same topics used in question one.

Highly established. As a result of this division, four of the 17 survey items $(7 b, 8 a d e)$ demonstrated a highly established rate of $51 \%$ or higher by all stakeholders as can be seen in Table 7. As mentioned in question one, these items correlate closely to the beginning initiatives of RTI implementation established in the state of WV. These survey items coincided with the areas of instruction and assessment. The items related specifically to an arranged schedule which included intervention blocks $(7 b)$, an established universal screening process that occurred three times a year $(8 a)$, a data system in place to maintain results $(8 d)$, as well as, a predetermined schedule for assessments $(8 e)$, which included progress monitoring and benchmark assessments, and the schedule for delivery and completion of these assessments. 
Table 7

Survey Items: $51 \%$ or Higher Established by All Stakeholders

\begin{tabular}{|c|c|c|c|c|c|c|}
\hline & & Position & Established & $\begin{array}{l}\text { Making } \\
\text { Progress }\end{array}$ & Emerging & Not In Place \\
\hline & & & $\underline{\%}$ & $\underline{\%}$ & $\underline{\%}$ & $\underline{\%}$ \\
\hline \multirow{5}{*}{ 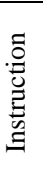 } & 7b. Intervention blocks are clearly & CT & 78.6 & 11.6 & 4.5 & 5.4 \\
\hline & designated in the master school & RS & 81 & 14.3 & 0 & 4.9 \\
\hline & schedule. & SP & 67.6 & 29.4 & 0 & 2.9 \\
\hline & & $\mathrm{P}$ & 93.3 & 6.7 & 0 & 0 \\
\hline & & CA & 80 & 20 & 0 & 0 \\
\hline \multirow{15}{*}{ 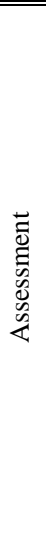 } & 8a. Universal screening occurs 3 times &  & 78.6 & 7.8 & 5.8 & 7.8 \\
\hline & a year. & RS & 100 & 0 & 0 & 0 \\
\hline & & SP & 85.3 & 8.8 & 2.9 & 2.9 \\
\hline & & $\mathrm{P}$ & 80 & 13.3 & 6.7 & 0 \\
\hline & & $\mathrm{CA}$ & 100 & 0 & 0 & 0 \\
\hline & 8d. Our school has a data system in & $\mathrm{CT}$ & 69.1 & 15.5 & 6.4 & 9.1 \\
\hline & place for both progress monitoring and & RS & 75 & 20 & 5 & 0 \\
\hline & benchmark assessments. & SP & 64.7 & 26.5 & 5.9 & 2.9 \\
\hline & & $\mathrm{P}$ & 66.7 & 13.3 & 20 & 0 \\
\hline & & CA & 60 & 20 & 20 & 0 \\
\hline & 8e. Teachers follow a predetermined & $\mathrm{CT}$ & 64.5 & 19.1 & 7.3 & 9.1 \\
\hline & schedule for benchmark and progress & RS & 61.9 & 28.6 & 4.8 & 4.8 \\
\hline & monitoring assessments. & SP & 61.8 & 26.5 & 5.9 & 5.9 \\
\hline & & $\mathrm{P}$ & 53.3 & 26.7 & 20 & 0 \\
\hline & & CA & 60 & 20 & 20 & 0 \\
\hline
\end{tabular}

Moderately established. Ten of the 17 Likert items resulted in a mixed pattern of ratings, with some stakeholders on each item assigning an established rating at $51 \%$ or higher as evidenced in Table 24. These items connected to both strong Tier I instruction and the development of a master schedule that provided for both Tier II and Tier III instruction, as well as, placement in the Instruction category. With regard to Tier I/Tiered model training $(6 d)$, the involvement of the eligibility committee in design and preparation of the master schedule $(9 g)$, and tiered instruction that related to the West Virginia Content Standards and Objectives (11d), Principals ranked each of these items highly established, despite the fact that Special Educators without fail ranked all three survey items not established. However, the remaining stakeholder results did not indicate an obvious pattern of ratings. 
The next three items can be easily placed within the Collaboration and Problem Solving category as they related to a dedicated time for data analysis $(7 e)$, specified training for eligibility committees on proper parent communication (9f), and involvement of teachers with personnel decisions (10f). While these three items were ranked as highly established by principals, classroom teachers and special educators ranked all items as not established. Both reading specialists and county level administrators returned mixed ratings on these items.

The remaining items related specifically to Professional Development. Survey results (Table 8) suggested that professional development on the components of the Three Tier model (10e), professional development with regard to designing and delivering intervention (10g), professional development with an emphasis on data analysis $(11 c)$, and teacher involvement in professional learning communities (11e) were found to be varied. County level administrators ranked each of the four items as highly established. However, a consistent pattern did not emerge for the remaining stakeholders with the exception of classroom teachers who ranked all the items as not established. 
Table 8

Survey Items: Mixed Ratings of 51\% or Higher Established

\begin{tabular}{|c|c|c|c|c|c|c|}
\hline & & Position & Established & $\begin{array}{l}\text { Making } \\
\text { Progress }\end{array}$ & Emerging & Not In Place \\
\hline & & & $\underline{\%}$ & $\underline{\%}$ & $\underline{\%}$ & $\underline{\%}$ \\
\hline \multirow{15}{*}{  } & 6d. Teachers have received instruction & CT & 50 & 24.1 & 13.9 & 12.0 \\
\hline & on strengthening Tier 1 instruction in & $\mathrm{RS}$ & 52.4 & 38.1 & 9.5 & 0 \\
\hline & reading and have become familiar with & $\mathrm{SP}$ & $40 *$ & 45.7 & 2.9 & 11.4 \\
\hline & Tiered Models and intervention & $\mathrm{P}$ & 66.7 & 33.3 & 0 & 0 \\
\hline & language. & CA & 80 & 20 & 0 & 0 \\
\hline & 9g. ECs have been involved in the & CT & $18.8 *$ & 31.7 & 16.8 & 32.7 \\
\hline & development of a master school & $\mathrm{RS}$ & $15 *$ & 15 & 25 & 45 \\
\hline & schedule to include capacity for Tier 2 & SP & $12.1 *$ & 30.3 & 24.2 & 33.3 \\
\hline & and Tier 3 interventions & $\mathrm{P}$ & 58.3 & 8.3 & 16.7 & 16.7 \\
\hline & & $\mathrm{CA}$ & $25 *$ & 75 & 0 & 0 \\
\hline & 11d. Teachers have been introduced to & CT & 55.9 & 27.9 & 10.8 & 5.4 \\
\hline & tiered instruction and integration with & RS & 70 & 15 & 15 & 0 \\
\hline & West Virginia Content Standards and & SP & $47.2 *$ & 33.3 & 13.9 & 5.6 \\
\hline & Objectives. & $\mathrm{P}$ & 78.6 & 21.4 & 0 & 0 \\
\hline & & $\mathrm{CA}$ & 100 & 0 & 0 & 0 \\
\hline \multirow{15}{*}{ 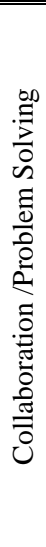 } & 7e. Teachers have been provided & "CT & $37.8 *$ & 21.6 & 18.9 & 21.6 \\
\hline & dedicated time to analyze data and & $\mathrm{RS}$ & $50 *$ & 30 & 20 & 0 \\
\hline & plan collaboratively & SP & $31.4 *$ & 31.4 & 20 & 17.1 \\
\hline & & $\mathrm{P}$ & 80 & 13.3 & 6.7 & 0 \\
\hline & & $\mathrm{CA}$ & $40 *$ & 20 & 40 & 0 \\
\hline & 9f. ECs have received information & CT & $24.5 *$ & 32.7 & 20.4 & 22.4 \\
\hline & about how to communicate with & RS & $16.7 *$ & 22.2 & 11.1 & 50 \\
\hline & parents about the 3 -Tier instructional & $\mathrm{SP}$ & $27.3 *$ & 33.3 & 21.2 & 18.2 \\
\hline & model & $\mathrm{P}$ & 57.1 & 28.6 & 14.3 & 0 \\
\hline & & $\mathrm{CA}$ & $50 *$ & 50 & 0 & 0 \\
\hline & 10f. Teachers have assisted with the & CT & $42.5 *$ & 20.8 & 15.1 & 21.7 \\
\hline & determination of which personnel will & $\mathrm{RS}$ & 65 & 20 & 5 & 10 \\
\hline & administer assessments. & $\mathrm{SP}$ & $32.4 *$ & 44.1 & 14.7 & 8.8 \\
\hline & & $\mathrm{P}$ & 73.3 & 13.3 & 13.3 & 0 \\
\hline & & $\mathrm{CA}$ & 75 & 25 & 0 & 0 \\
\hline \multirow{20}{*}{ 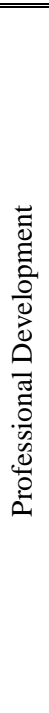 } & 10e. Teachers have received & $\overline{\mathrm{CT}}$ & 43.9* & 29 & 15.9 & 11.2 \\
\hline & professional development in & $\mathrm{RS}$ & 66.7 & 19 & 9.5 & 4.8 \\
\hline & establishing the components of a 3-tier & SP & 52.8 & 30.6 & 16.7 & 0 \\
\hline & model. & $\mathrm{P}$ & 73.3 & 13.3 & 13.3 & 0 \\
\hline & & $\mathrm{CA}$ & 100 & 0 & 0 & 0 \\
\hline & 10g. Teachers have received & CT & $36^{*}$ & 27 & 20 & 17 \\
\hline & professional development for special & RS & $50 *$ & 35 & 5 & 10 \\
\hline & education and Title 1 teachers in & SP & $36.1^{*}$ & 33.3 & 13.9 & 16.7 \\
\hline & designing and delivering interventions. & $\mathrm{P}$ & $46.2^{*}$ & 46.2 & 7.7 & 0 \\
\hline & & $\mathrm{CA}$ & 75 & 25 & 0 & 0 \\
\hline & 11c. Teachers have received training & $\mathrm{CT}$ & $44.6^{*}$ & 33 & 9.8 & 12.5 \\
\hline & in data analysis, grouping students for & RS & 63.2 & 15.8 & 5.3 & 15.8 \\
\hline & intervention, and intervention lesson & SP & $38.9^{*}$ & 36.1 & 22.2 & 2.8 \\
\hline & planning. & $\mathrm{P}$ & $42.9 *$ & 35.7 & 21.4 & 0 \\
\hline & & $\mathrm{CA}$ & 75 & 25 & 0 & 0 \\
\hline & 11e. Teachers have been involved in & $\mathrm{CT}$ & $44.1^{*}$ & 28.8 & 14.4 & 12.6 \\
\hline & professional learning communities & $\mathrm{RS}$ & $45^{*}$ & 15 & 15 & 25 \\
\hline & & SP & $36.1^{*}$ & 41.7 & 11.1 & 11.1 \\
\hline & & $\mathrm{P}$ & 50 & 42.9 & 7.1 & 0 \\
\hline & & $\mathrm{CA}$ & 75 & 25 & 0 & 0 \\
\hline
\end{tabular}

Note. Items marked with an * indicate a rating of $50 \%$ or below. 
Not established. The final three of the 17 Likert items fall into the categories of Instruction and Collaboration and Problem Solving. These items pertained to teacher involvement in the selection of a delivery model ( $7 f$ for intervention that provides guidance on personnel, schedules, and instructional spaces $(9 h)$ and strategies for monitoring implementation $(8 f)$ and were rated not established by all stakeholders.

Table 9

Survey Items: Ranked $50 \%$ or Below by All Stakeholders

\begin{tabular}{|c|c|c|c|c|c|c|}
\hline & & Position & Established & $\begin{array}{l}\text { Making } \\
\text { Progress }\end{array}$ & Emerging & Not In Place \\
\hline & & & $\%$ & $\%$ & $\%$ & $\%$ \\
\hline \multirow{10}{*}{ :气 } & \multirow{5}{*}{$\begin{array}{l}\text { 7f. Teachers have been included in the } \\
\text { selection of a model for delivering } \\
\text { intervention that delineates personnel, } \\
\text { schedules, and instructional spaces. }\end{array}$} & $\mathrm{CT}$ & $28.8^{*}$ & 25 & 11.5 & 34.6 \\
\hline & & RS & $33.3^{*}$ & 19 & 23.8 & 23.8 \\
\hline & & SP & $22.9 *$ & 45.7 & 14.3 & 17.1 \\
\hline & & $\mathrm{P}$ & $46.7 *$ & 40 & 13.3 & 0 \\
\hline & & $\mathrm{CA}$ & $20 *$ & 20 & 40 & 20 \\
\hline & \multirow{5}{*}{$\begin{array}{l}\text { 8f. Teachers have developed strategies } \\
\text { for monitoring implementation of } \\
\text { research-based reading strategies. }\end{array}$} & $\mathrm{CT}$ & $41.5^{*}$ & 37.7 & 17 & 3.8 \\
\hline & & RS & $23.8^{*}$ & 57.1 & 19 & 0 \\
\hline & & SP & $30.3^{*}$ & 57.6 & 6.1 & 6.1 \\
\hline & & $\mathrm{P}$ & $46.7^{*}$ & 33.3 & 20 & 0 \\
\hline & & $\mathrm{CA}$ & $40 *$ & 20 & 40 & 0 \\
\hline \multirow{5}{*}{ 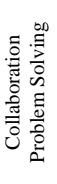 } & \multirow{5}{*}{$\begin{array}{l}\text { 9h. ECs have assisted in the } \\
\text { arrangement of staffing to provide } \\
\text { Tier } 2 \text { and Tier } 3 \text { interventions }\end{array}$} & $\mathrm{CT}$ & $18.1 *$ & 27.6 & 20 & 34.3 \\
\hline & & RS & $10.5^{*}$ & 21.1 & 10.5 & 57.9 \\
\hline & & SP & $9.1 *$ & 30.3 & 18.2 & 42.4 \\
\hline & & $\mathrm{P}$ & $40 *$ & 10 & 30 & 20 \\
\hline & & $\mathrm{CA}$ & $25^{*}$ & 75 & 0 & 0 \\
\hline
\end{tabular}

Note. Items marked with an * indicate a rating of $50 \%$ or below.

Survey participants ranked the listed survey items with mixed results with regard to established practices within the implementation processes and procedures of RTI. County level administrators and principals, frequently used established ratings, while for the most part, classroom teachers, special educators and reading specialists ranked the practices as not established in several instances.

Research question three: Perceptions by position. The third research question determined differences in perceptions of RTI implementation based on respondent position. The 
first one-way ANOVA examined current position of respondents and the results revealed no statistical significance on survey items 6abc, 7abcde, 8abcd, 9abcdef, 10abcd and 11abcde. As a result of these findings, post hoc comparisons proved unnecessary.

Table 10

Questions with No Statistical Significance

\begin{tabular}{|c|c|}
\hline Question \# & Areas of Implementation \\
\hline 6abcd & $\begin{array}{l}\text { Tier group times and appropriate Professional } \\
\text { Development }\end{array}$ \\
\hline 7 abcde & $\begin{array}{l}\text { Scheduling, group size, stakeholder involvement in } \\
\text { material selection }\end{array}$ \\
\hline 8abcd & $\begin{array}{l}\text { universal screening, progress monitoring, data collection } \\
\text { systems }\end{array}$ \\
\hline 9abcdef & $\begin{array}{l}\text { planning, shared responsibility and decision making, } \\
\text { placement and referral }\end{array}$ \\
\hline 10abcd & $\begin{array}{l}\text { professional development on programming and data } \\
\text { analysis }\end{array}$ \\
\hline 11abcde & data collection, training, learning community \\
\hline
\end{tabular}

The second one-way ANOVA examined items related to data analysis, eligibility committees, professional development, and personnel placement. Results revealed significant differences across current position: $7 e-F(4,182)=3.49, p<.05 ; 9 f-F(4,162)=3.95, p<.05$; $9 g-F(4,165)=2.57, p<.05 ; 10 e-F(4,178)=2.75, p<.05 ;$ and $10 f-F(4,174)=2.58, p<.05$; therefore, necessitating post hoc comparisons. In three instances, the Tukey Honestly Significant Difference (HSD) test did not show significance due to unequal group sizes, as the Tukey test assumes that samples sizes are equal. In those instances, the researcher used the Games-Howell 
test to complete post hoc comparisons as it does not assume population variances are equal

(Table 11).

Table 11

Items with Statistical Significance

\begin{tabular}{|c|c|c|c|}
\hline Question & \multicolumn{2}{|c|}{ Position } & Level of Significance \\
\hline $\begin{array}{l}\text { 7e. Teachers have been } \\
\text { provided dedicated time } \\
\text { to analyze data and plan } \\
\text { collaboratively }\end{array}$ & Principals & $\begin{array}{l}\text { Classroom Teachers } \\
\text { Special Educators }\end{array}$ & $\begin{array}{l}.011 \\
.037\end{array}$ \\
\hline $\begin{array}{l}\text { 9f. ECs have received } \\
\text { information about how } \\
\text { to communicate with } \\
\text { parents about the } 3 \text {-Tier } \\
\text { instructional model }\end{array}$ & Principals & Reading Specialists & .004 \\
\hline $\begin{array}{l}\text { 9g. ECs have been } \\
\text { involved in the } \\
\text { development of a } \\
\text { master school schedule } \\
\text { to include capacity for } \\
\text { Tier } 2 \text { and Tier } 3 \\
\text { interventions }\end{array}$ & Principals & Reading Specialists & $.033 *$ \\
\hline $\begin{array}{l}\text { 10e. Teachers have } \\
\text { received professional } \\
\text { development in } \\
\text { establishing the } \\
\text { components of a 3-tier } \\
\text { model. }\end{array}$ & Classroom Teachers & $\begin{array}{l}\text { Special Educators } \\
\text { County Level } \\
\text { Administrators }\end{array}$ & $\begin{array}{l}.000 * \\
.000 *\end{array}$ \\
\hline $\begin{array}{l}\text { 10f. Teachers have } \\
\text { assisted with the } \\
\text { determination of which } \\
\text { personnel will } \\
\text { administer assessments }\end{array}$ & Principal & Classroom Teacher & $.017 *$ \\
\hline
\end{tabular}

Note. A Tukey post-hoc test was conducted on all test items (7e, 9fg, 10ef). Items marked with* showed no significance with the Tukey test, therefore, a Games-Howell test was conducted.

To determine the difference of perceptions among stakeholders in the area of dedicated time to analyze data and plan collaboratively, a one-way ANOVA was performed indicating a significant difference in the perceptions of principals as opposed to those of classroom teachers and special educators. A large $F$-ratio indicates that the differences between stakeholders on $7 e$ $(F$-ratio $=3.489)$, are greater than chance and a significant effect exists (Table 12$)$. This can also 
be seen in survey item $9 f(F$-ration $=3.949)$ which pertains to the ability to communicate information to parents regarding the 3-Tier Model. A significant difference existed between principals and reading specialists on this item.

Table 12

One-Way Analysis of Variance Summary

7e-Teachers have been provided dedicated time to analyze data and plan collaboratively

\begin{tabular}{lcccc}
\multicolumn{1}{c}{ Source } & $d f$ & $S S$ & $M S$ & $F$ \\
\hline Between Groups & 4 & 16.521 & 4.130 & 3.489 \\
Within Group & 182 & 213.737 & 1.181 & \\
Total & 186 & 230.258 & & \\
\hline
\end{tabular}

${ }^{* *} p<.05$

9f-Eligibility committees have received information about how to communicate with parents about the 3-Tier Model

\begin{tabular}{lcccc}
\multicolumn{1}{c}{ Source } & $d f$ & SS & $M S$ & $F$ \\
\hline Between Groups & 4 & 18.140 & 4.535 & 3.949 \\
Within Group & 162 & 186.016 & 1.148 & \\
Total & 166 & 204.156 & & \\
\hline
\end{tabular}

$* * p<.05$

The remaining three items, $9 g, 10 e$ and $10 f$ exhibited significance with $F$-ratios of 2.572 , 2.746, and 2.577, respectively (Tables 14). Item $9 g$ showed a significant difference in responses between principals and reading specialists, while $10 f$ demonstrated a significant difference between principals and classroom teachers. However, with item 10e significance existed among responses by classroom teachers and those of special educators and county level administrators. 
Table 13

One-Way Analysis of Variance Summary

9g-Eligibility Committees have been involved in the development of a master school schedule to include capacity for Tier II and Tier III interventions

\begin{tabular}{lcccc}
\multicolumn{1}{c}{ Source } & $d f$ & $S S$ & $M S$ & $F$ \\
\hline Between Groups & 4 & 12.761 & 3.190 & 2.572 \\
Within Group & 165 & 204.627 & 1.240 & \\
Total & 169 & 217.388 & & \\
\hline$* * p<.05$ & & & &
\end{tabular}

10e-Teachers have received professional development in establishing the components of a 3-Tier Model

\begin{tabular}{lcccc}
\multicolumn{1}{c}{ Source } & $d f$ & $S S$ & $M S$ & $F$ \\
\hline Between Groups & 4 & 9.553 & 2.388 & 2.746 \\
Within Group & 178 & 154.807 & .870 & \\
Total & 182 & 164.361 & & \\
$* * *<.05$ & & & &
\end{tabular}

10f-Teachers have assisted with the determination of which personnel will administer assessments

\begin{tabular}{lcccc}
\multicolumn{1}{c}{ Source } & $d f$ & $S S$ & $M S$ & $F$ \\
\hline Between Groups & 4 & 12.304 & 3.076 & 2.577 \\
Within Group & 174 & 207.674 & 1.194 & \\
Total & 178 & 219.978 & & \\
\hline
\end{tabular}

$* * p<.05$

Research question four: Barriers to implementation. The fourth research question used an open-ended, free response design to allow stakeholders to reveal barriers within the implementation process. Participants responded with a variety of responses, some of which included more than one barrier area. The IRA RTI Guiding Principles for Educators and research on implementation by Fixsen et al (2005). established a priori codes. Fixsen et al. state that 
“...the most essential and indispensable components of an implementation practice or program"

(p. 24) are the core components of implementation, including "staff selection, pre-service and inservice training, ongoing consultation and coaching, staff and program evaluation, facilitative administrative support and systems interventions" (Fixsen et al., p. 28). Predetermined codes included people and policy/procedures. The work of Moustakis (1994) suggested the development of text-based descriptors or themes that clearly denote the beliefs of the respondents. Many of the responses incorporated variations (Moustakis, 1994) that connected the experiences of the stakeholders. Emerging codes were also noted as they appeared. Themes and sub categories detailed in respondent comments included people, policy/procedure, time constraints, schedules, and training/professional development (Table 14).

Table 14

Themes Found in Responses from Stakeholders

\begin{tabular}{llc}
\hline Theme & & Total Response \\
\hline People & a. Staffing/Personnel & 124 \\
\hline Policy/Procedures & a. Policy & 26 \\
& b. Communication & 23 \\
c. Materials/Resources & 8 \\
d. Funding & 6
\end{tabular}

Time Constraints 79

Schedules 61

Training/Professional Development 41 
People. Through data analysis, issues of Staffing characterized a significant barrier to implementation and appeared in 124 responses. One reading specialist replied "too many students to serve and not enough interventionists," while another found there was "not enough staff to reach the number of children who are at risk." Many responses from both teachers and principals cited a deficiency in "number of staff needed to reduce groups to 1-3 or 3-5," which is a core requirement in the implementation process. Respondent comments, such as "Title I being spread too thin--working with too many classrooms and too many students," indicated areas of concern by both special educators and reading specialists. All stakeholders, with the exception of county level administration, reported that while some are being asked to cover many classrooms and work with numerous children, they are also experiencing a "Cut back in staffing...... we lost a Title I position this year because of lack of funding," which adds to the burden of meeting the needs of all students.

Policy/Procedures. For the purposes of this research, policy/procedures will be defined as a definitive plan of action or procedure to be adopted by a group or organization. Survey respondents stated policy issues resulting in barriers to implementation a total of 26 times. One special educator stated "not enough information is known to have a solid middle school model," while a classroom teacher commented that "we are forced to use a program by our county, that has disrupted our schedule and has questionable outcomes." The procedures for record keeping mentioned by a reading specialist articulated "it seems that every year we are given a new form for record keeping... and cannot get a straight answer which documentation is needed for special education services" which indicated issues with policy. Another concern raised by classroom teachers indicated that "not all involved in the RTI process have been given the opportunity to 
collaborate," as well as, receiving "different messages as to tier group size and time spent doing this intervention."

Sub-themes. Communication. Communication is essential at all levels of implementation. Many respondents stated limited communication existed across multiple stakeholders. One classroom teacher stated "we are getting different messages as to the tier groups," while another commented that "regular education teachers have very little say in what goes on with RTI." Another area of concern offered by a reading specialist indicated "mixed messages from administration as to what is accepted if a student is referred for testing."

Materials/Resources. Without the proper materials and resources, initiatives often fail. With regard to this area, classroom teachers, reading specialists, and special educators mentioned “we have no materials," as well as, "teachers lack materials" for proper implementation. Another respondent from this group also remarked that a solid barrier to implementation was "finding enough... resources for dedicated professionals to do what they need to do."

Funding. The area of funding bridged several of the other themes as evidenced by respondent comments. Statements from classroom teachers, reading specialists, and county level administration alluded to "limited funding for training on Research Based RTI programs" exists; whereas, another mentioned a "cut back in staffing....because of lack of funding." A final response in this category implied a misuse of funding by stating, "Funding is not being used for coaches, RTI interventionist, etc.”

Time constraints. The time constraints offered by respondents covered numerous areas time for planning, assessment, intervention, material design, and collaboration. Overwhelmingly, classroom teachers expressed "there are simply not enough hours in the day," while another stated "the time element during the day continues to be a problem." Classroom teachers, special 
educators, and reading specialists described issues such as a lack of "planning time or collaboration time," "doesn't seem to be enough time to manage all the interventions," as well as "no built-in time to analyze results." One classroom teacher also articulated the need for more “time to develop intervention centers."

Schedules. Many aspects of scheduling play an important role in the successful implementation of RTI. Survey responses indicated numerous comments that connected directly to scheduling issues. One classroom teacher responded with "Our schedule is not working...groups of 25 to 27 in 'RTI' classes," while a special educator agreed that "groups are much larger than recommended on this survey." Many respondents from the stakeholder groups of classroom teachers, special educators, and reading specialists stated that limitations in the schedule also influence the time for assessment and teacher ability to effectively meet the needs of all students.

Training/Professional development. The necessity of a highly trained teaching force determines both success of students and schools. Statements regarding training and professional development suggested that stakeholders' concerns, as evidenced by the following comments. Respondents from all stakeholder groups commented frequently that "more training would be beneficial," whereas, others stated the need for additional professional development related to "basic understanding of RTI." A consensus existed among respondents from both the classroom teacher and reading specialist's stakeholder groups that "Tier I needs to be strengthened and strong Tier II lessons need to be in place."

\section{Results of Peer Review of Survey Responses}

The responses related to survey question four, were reviewed by two peer reviewers and found to correspond with the researcher on the overall significant themes. The two reviewers 
received a copy of responses in table format and asked to highlight themes as they became apparent. The most significant themes derived from the survey responses indicated Staffing/Personnel and Time issues. The themes found by the reviewers closely matched those found by the researcher. The data triangulation with peer review, contribute to the study's reliability and validity with respect to the themes established by the researcher. The themes can be found in Table 15 in the order of significance as determined by the reviewers. Both reviewers clearly had exact rankings, with the exception of Communication and Funding; where reviewer results were switched (Reviewer 1 - Communication (5), Funding (6); Reviewer 2 - Funding (5) and Communication (6)).

Table 15

Peer Review

\begin{tabular}{lcc} 
Theme & Reviewer 1 Ranking & Reviewer 2 Ranking \\
\hline Staffing/Personnel & 1 & 1 \\
\hline Time Constraints & 2 & 2 \\
\hline Schedules & 3 & 3 \\
\hline Training/Professional Development & 4 & 4 \\
\hline Funding & 6 & 5 \\
\hline Communication & 5 & 6 \\
\hline Materials/Resources & 7 & 7 \\
\hline Policy & 8 & 8 \\
\hline
\end{tabular}

The results presented in this chapter markedly signify the stakeholders in this study encountered difficulty in the implementation processes and procedures of RTI. A summary and comprehensive discussion of the study findings are detailed in Chapter 5. 


\section{CHAPTER 5}

\section{CONCLUSIONS, RECOMMENDATIONS, SUMMARY}

This chapter presents a brief summary of the purpose, research questions, and results of the study. Conclusions, recommendations for practice, and recommendations for future research are also presented.

The purpose of this study was to gauge the implementation level of the nationally mandated RTI initiative in West Virginia (WV) in respect to multiple stakeholders in three West Virginia county school districts. Participants were asked to rate implementation on the following scale: Established, Making Progress, Emerging, and Not in Place, as it pertained to their school or district. An additional question solicited open responses associated with barriers to implementation.

Fuchs, Fuchs, and Vaughn (2008), as well as, Mellard and Johnson (2008), and Fixsen et al. (2005) suggested that without fidelity of implementation, success will be short-lived. Mellard and Johnson (2008) also discuss the difficulty of implementation with regard to different interpretations and agendas. A small number of resources were found with regard to the barriers of implementation. To begin, I will present several conclusions that emerged from the data collected and presented in Chapter 4, and then I will provide recommendations for stakeholders to enhance the implementation processes for all parties. In addition, limitations and recommendations for further research will also be included.

\section{Conclusions}

Conclusion I: Stakeholder position does effect perceived implementation status. As evidenced by the survey results, stakeholder position does effect perceived implementation status. There was little common ground between administrators and teachers on multiple areas of 
implementation. While this was highlighted within the survey results, the survey did not solicit specific reasons for the lack of congruence. The use of effective communication implies that schools that implement RTI successfully, spend necessary time in collaboration with all stakeholders. Burns and Gibbons (2012) agreed that the discussion about RTI must continue to inform decision making.

Conclusion II: Numerous variables impact implementation. As with any initiative or innovation, numerous variables impact implementation. Within the survey results, patterns emerged with regard to the following areas: personnel, time constraints and scheduling, professional development, and appropriate funding and resource allocation. Along with policy mandates for programming, policy makers and stakeholders need to collaborate on implementation strategies. Survey respondents articulated that appropriate personnel are essential to successful implementation. These comments included, but were not limited to, providing adequate personnel to implement RTI, as well as, personnel with sufficient training which also ties closely to time for implementation and the amount of funding available to ensure fidelity of implementation. Bernhardt and Hébert (2011) affirmed that it is necessary to realign current resources with regard to personnel, time, and funding. Success is within reach, but it will be necessary for difficult conversations to take place and communication between stakeholders must become a priority.

\section{Discussion}

Weishaar and Weishaar (2012) postured that the people, events and systems simultaneously affect one another. Involvement and interconnectedness from all systems is essential for success. Three primary systems, which included the classroom system (teachers), the school building system (principals), and the district-wide system (superintendents, literacy 
coaches), are crucial to influence change. This three level system (district, school, and classroom) is used to discuss research findings.

Across this three level system, the assumption can be made that those involved with the implementation intend to keep their commitment to Burns and Gibbons (2012) suggested five areas that assist stakeholders in efficiently managing an educational change. These include "(a) the vision must be articulated, (b) educators need skills to intervene with students below target and analyze instructional data, (c) incentives need to be in place, (d) adequate resources need to be provided to support the system, and (e) action plans must be clearly defined and shared with all stakeholders" (p. 158). However, this study found that a disconnection existed between the initial plan and the efficient management of the implementation at each of Weishaar and Weishaar's (2012) levels.

Also evidenced by the results, in many of the schools surveyed, the school administrator is not serving in a strong RTI leadership capacity. This leadership capacity is an important element in the implementation success. Bernhardt and Hébert (2011) stated that "successful RTI systems rely on leadership of a strong principal to bring general educators, special educators, speech and language therapists, school psychologists, school counselors, Title I specialists, and instructional specialists together..." (p. 101). This study found that the implementation processes and procedures were limited and indicates that all stakeholders must be willing to actively participate in the intended change in order to sustain a successful initiative.

District-level system. A finding related to the quantitative research indicated that county level administrators (district level) believed that the practices related to this area, which included scheduling, group size, strategy development and training, and delivery models, rated this as not established at $25 \%$, while school administrators (building level) rated that the practices were 
highly established at a rate of $62 \%$. Classroom teachers, reading specialists and special educators (classroom level) rank this not established at a combined rate of 33\%. Qualitative analysis of open responses also indicated a detachment here as can be seen in these claims by respondents (classroom teachers, reading specialists, and special educators), "lack of materials, lack of adequate staffing, lack of training” and “...need for time to develop necessary materials.” While others stated "Our schedule is not working" and there is "limited funding for training on research based RTI programs.” These findings indicate a discrepancy within the level of consensus that currently exists. Burns and Gibbons (2012) and Brown-Chidsey and Steege (2010) both suggested building understanding is the means to successful implementation. At the crux of this consensus existed a need for "regular and ongoing communication" (p. 159). Given the results of this survey, consensus is absent, and communication is nearly nonexistent as evidenced by the varying degrees of response on a variety of items across stakeholders.

As indicated across the survey respondents, while agreement of implementation level appeared somewhat in place and even making some progress, discord and confusion did exist among the stakeholders at all system levels. Research indicated that district level administrators/literacy coaches must create guidelines and implementation processes and protocols, as well as develop guidelines, checklists, and rubrics to streamline the implementation process. While a few checklists and rubrics exist (e.g., Hall, 2008; WVDE, 2007) to assist with implementation status levels, real face-to-face conversations are what should occur at this juncture to create the necessary guidelines. The primary responsibility of the district level is to create a dialogue and understanding of the implementation process. As a result of these face-toface conversations, additional checklists and rubrics could be developed to promote understanding for improved implementation. These findings support Burns and Gibbons (2012) 
detailed use of infrastructure as a means of reinforcing and maintaining RTI. It is suggested that the development of an infrastructure "involves identifying supports already in place for implementation of the framework, determining needs, designing or adopting a data management system, and creating policies and procedures to define implementation” (Burns \& Gibbons, 2012, p. 160).

Building-level system. "Decades of school effectiveness research found that the only variable that always mattered was effective instructional leadership by the school principal" (VanDerHayden \& Burns, 2010, p. 103). On many of the issues related to RTI implementation, responses displayed by principals indicated a somewhat 'rosy' view of the process. Of the items related directly to professional development and assessment, these stakeholders felt the process was highly established at $67 \%$.

Although at face value it seems, as a result of principal viewpoints, that implementation is moving forward at a successful rate, classroom level participants (classroom teachers, reading specialists and special educators) do not agree. As successful implementation requires the effort and capacity of all stakeholders, a lack of support at one level will seriously undermine the entire process. A necessity exists for the school level administration to become immersed in the school RTI culture in an effort to assist teachers with successful implementation. The administrator must look beyond the face value of implementation and develop a clear picture of what is taking place and exactly where the classroom level is experiencing difficulty.

Classroom-level system. As reflected in the research results, many classroom teachers, special educators, and reading specialists believed that screening of all students and regular progress monitoring were solidly in place and supported. However, these groups do not feel that they have the necessary resources to successfully implement with regard to core curriculum and 
tiered intervention. Many respondents suggested that a lack of funding and training severely limited their successes with effective interventions.

\section{Summary}

As proposed by Fullan (2010), all parts of the system must work individually and cohesively to ensure success. He also reiterates that "all means all" and that fragmented implementation is unsuccessful. "Educational innovations come and go with alarming frequency, and RTI has the potential to join the long list of abandoned shipwrecks despite consistency with theory, a solid research base, and consistently demonstrated effectiveness" (VanDerHayden \& Burns, 2010, p. 103). During implementation, many schools lose momentum after the initial success dims and a determination is made to abandon the innovation (Burns \& Gibbons, 2012). Burns and Gibbons (2012) proposed that it is wise to "recognize [RTI] as a paradigmatic change rather than an intervention, model, or tool. It is instead a commitment to data based resource allocation and targeted intervention (p. 165)." As an innovation, RTI has the ability to be successful; however, all stakeholders must have open communication, humility, and openness to other's suggestions.

While it is clear from the survey results that the elements of time, staffing, and funding are problematic; it is also evident that school administrators are unaware of these concerns as corroborated by the disjointed responses from administrators and teachers (classroom, special education, and Title I). Successful implementation will continue to be delayed as long as Administrators, who have the power and authority to advocate for greater funding and staffing, do not comprehend the degree to which implementation is stunted.

As RTI in West Virginia has been replaced by Support for Specialized Learning (SPL), some of the issues inherent in my survey results have been superficially resolved. The most 
significant change pertains to time frames for each Tier level of instruction. Generally with RTI prior to April 2012, Tier I required 60-90 minutes of reading instruction, Tier II required five 30 minute sessions per week and Tier III required five 45-60 minute sessions per week. The expected Tier I minutes for instruction, as per Policy 2419, have been completely removed. The minute requirements for Tier II and III have also been lifted. With SPL, Tier I requires no specific time frame for daily instruction, Tier II requires three to five 15-30 minute sessions, and Tier III requires three to five 30-60 minute sessions. Torgesen et al. (2001) found a direct correlation to time spent in intensive intervention and reading progress. As WV moves forward with SPL implementation, time frames may need to be adjusted if student achievement declines as a result of the decrease in intervention time frames. Other areas of concern that should be noted from this research are as follows: procedures, stakeholders, balance of work load, and rigor (see Appendix J).

Three key elements of change, capacity building, transparency and leadership, as identified by Fullan, appeared to be critical impediments to the success of RTI. Fullan asserts "capacity building consists of the knowledge, skills, and dispositions of individuals and groups relative to the ability to do something according to a high standard" (p. 68). Within the scope of this research with regard to survey respondents, capacity building appears to be a problem area as it appears that RTI implementation is not occurring at a high standard. Without capacity, initiatives and innovations are destined for failure. The second area of concern, transparency, allows stakeholders to collaborate, investigate and measure new initiatives (Fullan, 2012). According to survey responses, stakeholder groups were often at odds as to the logistics of implementation of RTI. This creates a second stumbling block to change. The final area of interest responsible for successful change involves leadership, which Fullan refers to as "the 
ultimate cohesive driver" (p. 70). Within the survey results, many areas reported discrepancies between administrators and other stakeholders. Change cannot occur until all areas have been addressed and an open communication develops among all stakeholders.

\section{Limitations}

The results and conclusions are diminished by particular limitations, consequently minimizing the dexterity with which the findings can be generalized. Response rate, survey delivery, follow-up interviews, and underrepresentation of particular stakeholders create limitations with this research.

Although a reasonable population was surveyed, $n=770$, a return rate of $29.6 \%$ was garnered. This creates difficulty in generalizing the results to the educational community at large. If this study were to be replicated, it would be interesting to conduct site visits to speak with stakeholders about the importance of this research and the benefit of their thoughts and opinions about RTI implementation. It may also prove helpful to provide a computer station where participants could easily access the survey at the school at the time of the site visit.

The second limitation is the survey delivery method. Surveys were delivered electronically via email to building level administration and a request was made that the email be forwarded to teachers. During the first distribution, a return rate of $10 \%$ was achieved. Because distribution was placed in the hand of the 39 administrators, it is difficult to know if the initial notification reached the more than 700 teachers employed in the three surveyed counties. At this juncture, permission was requested and granted from county superintendents to send paper notices which included the link to the survey, to each school with a small incentive (tea, cocoa, chocolates). This resulted in a combined return rate of $29.6 \%$. A study of RTI implementation 
that works in tandem with the state educational agencies would provide greater support and perhaps better access to stakeholders.

The use of follow-up interviews within this study may have enriched the collected data on implementation. Information gained in interviews can often add depth to stakeholder responses that is often lacking in a written response. Interviews allow participants to expand on answers and clear any misconceptions with the researcher, the survey instrument, and the participant. An interview protocol could have been used to tease out themes and provide elaboration on the survey responses. This would allow for connectivity between the qualitative and quantitative data. Bernard (2006) stated the interviewer must be able to extract more information from the interviewee without superimposing their beliefs over the interviewee's response. Although the last item on the survey requested interview volunteers, zero responses were received offering a willingness to participate.

A final limitation can be seen in the underrepresentation of specific stakeholders. County level administration was the only group with a return rate beyond $50 \%$, with five out of six responding to the survey. School level administration showed a return rate of $46 \%$, with 18 out of 39 responding. However, the teacher/reading specialist/special educator group returned a response rate of only $28.3 \%$. Therefore, generalization of this group to similar group proves a limitation for this study. As a result of researcher error, the Literacy Coach position was absent from the current position question on the survey resulting in $0 \%$ return rate for this group. This oversight adds to the limitations represented by underrepresentation of specific stakeholders such as Literacy Coaches who are a vital part of the implementation process. 


\section{Recommendations for Further Research}

The topic of RTI requires further investigation and study from all previously mentioned levels on implementation processes and procedures. While ample research exists on the fundamentals of RTI, with regard to definitions and basic knowledge, there remains a limited amount of research on the actual processes and procedures related to implementation at all levels and with all stakeholders. As RTI is associated with public policy, it will in some form remain fixed in schools and classrooms. The IRAs Commission on Response to Intervention Position Statement established a definitive guide for implementation and sustainability issues and while this is a helpful, guiding document this research is in the first phase of development and necessitates further study.

Potential research on implementation processes and procedures across multiple counties is recommended. Although this study was germane and offered applicable knowledge into the processes and procedures of RTI across three counties, it was only a small percentage of areas within the state. While this study focuses wholly on the stakeholder perceptions of implementation, a future study could make comparisons across the surveyed counties, in addition to other demographic factors such as gender, age, level of degree, etc.

Policy makers and those at the highest levels of school administration have dictated, as per policy, that RTI must be implemented and assessment data must show reasonable gains. However, as with many education initiatives, time, funding, and professional development have been neglected in the equation for success. Perhaps, conclusions drawn from this study will propel policy makers and administrators to focus on the implementation processes and procedures needed for successful implementation of RTI. Although the conclusions of this study may represent only a small portion of the stakeholders involved in the RTI process, the results do 
point toward the fact that stakeholders have very differing opinions of the rates of implementation and the process of RTI. This lack of understanding and communication among the stakeholders is perhaps a finding of this research study that can propel state policy makers in a positive way toward further research on this initiative. Weishaar and Weishaar (2012) affirmed that school change is a pendulum, which comes and goes, however, RTI when implemented properly within systems, schools, and classrooms offers an opportunity to transform and positively influence learning for all students.

Since conclusion of this study, the WV department of education realigned RTI and replaced with Support for Personalized Learning. "The West Virginia Support for Personalized Learning (SPL) framework is a state-wide initiative that suggests flexible use of resources to provide relevant academic, social/ emotional and/or behavioral support to enhance learning for all students. SPL is characterized by a seamless system of high quality instructional practices allowing all students to sustain significant progress, whether they are considered at-risk, exceeding grade-level expectations or at any point along the continuum" (West Virginia Department of Education, 2012).

\section{Summary Statement}

Weishaar and Weishaar (2012) offered a clear and concise three level system that leads to successful implementation. The authors suggested that when practice, theory and research are connected to real-life implementation by all stakeholders, a cohesive method for shared decision making, as well as assessment and intervention is possible. If all stakeholders can unite to create rigorous implementation standards, create accountability measures, and continue with research based professional development, RTI will create positive change for students and our educational systems (VanDerHayden \& Burns, 2010). Many changes are necessary to further the 
implementation processes and procedures of RTI. Those in the field of education must realize stakeholders are not in the same place with their implementation and explore techniques to support successful implementation. It is essential for stakeholders to move forward with a clear purpose and blueprint for successful implementation and a clear understanding of the roles and responsibilities for each stakeholder. 


\section{REFERENCES}

Adams, J. G. (2013). Response to intervention framework and progress monitoring process: $K-3$ regular education teachers' perceptions (Doctoral dissertation, East Tennessee University). Retrieved from http://dc.etsu.edu/etd/1125

Allen, J., \& Dale, A. (1995). The school reform handbook: How to improve your schools. Washington, DC: The Center for Education Reform.

Allington, R. L. (2007). No quick fix: Rethinking literacy programs in America's elementary schools (the RtI edition). Teachers College, Columbia University.

Allington, R. (2009). What really matters in response to intervention: Research-based designs. Boston: Pearson.

Barnett, D. W., Daly, E. J., Jones, K. M., \& Lentz, F. E. (2004). Response to intervention: Empirically based special service decisions from single-case designs of increasing and decreasing intensity. The Journal of Special Education, 38, 66-79.

Barnett, D. W., VanDerHeyden, A. M., \& Witt, J. C. (2007). Achieving science-based practice through response to intervention: What it might look like in preschools. Journal of Educational and Psychological Consultation, 17, 31-54.

Berkeley, S., Bender, W., Peaster, L. \& Saunders, L. (2009). Implementation of response to intervention: A snapshot of progress. Journal of Learning Disabilities, 42(1), 85-95. doi10.1177/002219408326214

Bernard, R. (2006). Research methods in anthropology: Qualitative and quantitative approaches ( $4^{\text {th }}$ ed.). Lanham, MD: AltaMira Press. 
Bernhardt, V. L., \& Hébert, C. L. (2011). Response to intervention (RtI) and continuous school improvement (CSI): Using data, vision, and leadership to design, implement, and evaluate a schoolwide prevention system. New York, NY: Routledge, Inc.

Bollman, K. A., Silberglitt, B., \& Gibbons, K. A. (2007). The St. Croix River district model: Incorporating systems-level organization and a multi-tiered problem-solving process for intervention delivery. In S. R. Jimerson, M. K. Burns, \& A. M. VanDerHeyden (Eds.), Handbook of response to intervention: The science and practice of assessment and intervention (pp. 319-330). New York, NY: Springer.

Boulware-Gooden, R., Carreker, S., \& Conway, B. (2010). Perceptions and realities: What teachers and researchers say about response to intervention. Retreived from http://www.readingteachersnetwork.org/en/art/49

Bourque, L., \& Fielder, E. (2003). How to conduct and self-administered and mail surveys (2 $2^{\text {nd }}$ ed.). Thousand Oaks, CA: Sage Publications.

Bradley, R., Danielson, L., \& Doolittle, J. (2005). Response to intervention. Journal of Learning Disabilities, 38, 485-486.

Brown-Chidsey, R., \& Steege, M. W. (2005). Response to intervention: Principles and strategies for effective practice. New York: The Guilford Press.

Burns, M., \& Gibbons, K. (2012). Implementing response to intervention in elementary and secondary schools: Procedures to assure scientific-based practices. New York: Routledge. 
Callender, W. A. (2007). The Idaho results-based model: Implementing response to intervention statewide. In S. R. Jimerson, M. K. Burns, \& A. M. VanDerHeyden (Eds.), Handbook of response to intervention: The science and practice of assessment and intervention (pp. 331-342). New York, NY: Springer.

Compton, D. L., Fuchs, D., Fuchs, L. S., \& Bryant, J. D. (2006). Selecting at-risk readings in first grade for early intervention: A two-year longitudinal study of decision rules and procedures. Journal of Educational Psychology, 98, 394-409.

Denton, C., Fletcher, J., Anthony, J. \& Francis, D. (2006). An evaluation of intensive intervention for students with persistent reading difficulties. Journal of Learning Disabilities, 39, 447-466.

Denzin, N., \& Lincoln, Y. (2000). Handbook of qualitative research $\left(2^{\text {nd }}\right.$ ed.). Thousand Oaks, CA: Sage Publications.

Dillman, D. A. (1978). Mail and telephone surveys: The total design method. New York: Wiley Interscience.

Dillman, D. A. (2006). Mail and internet surveys: The tailored design method ( $2^{\text {nd }}$ ed.). Hoboken, NJ: John Wiley \& Sons.

Dole, J. (2004). The changing role of the reading specialist in school reform. The Reading Teacher, 57(5), 462-471.

Fink, A. (2003). The survey handbook (2 ${ }^{\text {nd }}$ ed.). Thousand Oaks, CA: Sage Publications.

Fixsen, D., Naoom, S., Blase, K., Friedman, R., \& Wallace, F. (2005). Implementation reseach: A synthesis of the literature. Tampa, FL: University of South Florida, Louis de la Parte Florida Mental Health Institute, The National Implementation Reserach Network. 
Forman, B. (2007). Primary prevention in classroom reading instruction. Teaching Exceptional Children, 39(5), 24-31.

Fowler, F. (2009). Survey research methods (4th ed.). Los Angeles: Sage Publications.

Fuchs, D., \& Fuchs, L. (2006). Introduction to response to intervention: What, why, and how valid is it? Reading Reserach Quarterly, 41(1), 93-99.

Fuchs, D., \& Fuchs, L. (2009). Responsiveness to intervention: Multilevel assessemnt and instruction as early identification and disability identificaiton. The Reading Teacher, $63(3), 250-252$.

Fuchs, D., Fuchs, L., \& Vaughn, S. E. (2008). Response to intervention: A framework for reading educators. Newark, DE: International Reading Association.

Fuchs, W., \& Bergeron, B. (2013). Viewpoints from the field: Impressions from teachers and administrators on the challenges and successes of RTI implementation in Illinois. Illinois Reading Council Journal, 41(2), 3-12. Retrieved from http://0ehis.ebscohost.com.library.acaweb.org/ehost/detail?vid=20\&sid=aed2bcc1-20af-4fabb2c932f114dcf267\%40sessionmgr15\&hid=15\&bdata=JnNpdGU9ZWhvc3QtbGl2ZQ\%3d\%3 $\mathrm{d} \# \mathrm{db}=\mathrm{a} 9 \mathrm{~h} \& \mathrm{AN}=85270393$

Fullan, M. (2007). The new meaning of educsational change (4th ed.). New York: College Press.

Fullan, M. E. (2009). The challenge of change: Start school improvement now! Thousand Oaks, CA: Corwin Press.

Fullan, M. E. (2010). All systems go: The change imperatie for whole system reform. Thousand Oaks, CA: Corwin Press. 
Fullan, M. (2012). Stratosphere: Integrating technology, pedagogy, and change knowledge. Toronto: Pearson .

Gersten, R., \& Dimino, J. (2006). RTI (Response to Intervention): Rethinking special education for students with reading disabilities (yet again). Reading Research Quarterly, 41, 99108.

Graden, J. L., Stollar, S. A., \& Poth, R. L. (2007). The Ohio integrated systems model: Overview and lessons learned. In S. R. Jimerson, M. K. Burns, \& A. M. VanDerHeyden (Eds.), Handbook of response to intervention: The science and practice of assessment and intervention (pp. 288-299). New York, NY: Springer.

Gravetter, F. J., \& Wallnau, L. B. (2007). Statistics for the behavioral sciences. ( $7^{\text {th }}$ ed.). Belmont, CA: Thomson Wadsworth.

Gresham, F. M. (2001). Responsiveness to Intervention: An Alternative Approach to the Identification of Learning Disabilities. Paper presented at the Learning Disabilities Summit, Washington DC.

Gresham, F. M. (2007). Evolution of the response-to-intervention concept: Empirical foundations and recent developments. In S. R. Jimerson, M. K. Burns, \& A. M. VanDerHeyden (Eds.), Handbook of response to intervention: The science and practice of assessment and intervention (pp. 10-24). New York, NY: Springer.

Gunning, T. G. (2010). Creating literacy instruction for all children ( $8^{\text {th }}$ ed.). Boston: Allyn and Bacon.

Hall, S. (2008). RTI action network: Checklists and forms. Retrieved from RTI Action Network, http://www.RTInetwork.org/images/content/downloads/get\%20started/hall_checklist.pdf 
Hardcastle, B., \& Justice, K. (2006). RTI and the classroom teacher: A guide for fostering teacher buy-in and suppoRTIng the intervention process. Horsham, PA: LRM Publications.

Hargreaves, A. (1995). Development and desire: A postmodern perspective. In T. R. Guskey, \& M. Huberman (Eds.), Professional development in education: New paradigms \& perspectives (pp. 9-34). New York: Teachers College Press.

Hill, D., King, S., Lemons, C., \& Partanen, J. (2012). Fidelity of implementation and instructional alignment in response to research. Learning Disabilities Research \& Practice, 27(3), 116-124. Retrieved from http://0ehis.ebscohost.com.library.acaweb.org/ehost/detail?vid=12\&sid=aed2bcc1-20af-4fabb2c932f114dcf267\%40sessionmgr15\&hid=15\&bdata=JnNpdGU9ZWhvc3QtbGl2ZQ\%3d\%3 $\mathrm{d} \# \mathrm{db}=\mathrm{a} 9 \mathrm{~h} \& \mathrm{AN}=78299579$

Hoover, J., Baca, L., Wexler-Love, E., \& Saenz, L. (2008, August). National Association of State Directors of Special Education, Inc. Retrieved from NASDSE: http://www.nasdse.org/Portals/0/NationalImplementationofRTI-ResearchSummary.pdf Howard, M. (2009). RTI from all sides: What every teacher needs to know. Portsmouth, NH: Heinemann.

IDEA. (2004). Individuals with Disabilities Education Improvement Act of 2004, Pub. L. No., 101-476, Stat. 2647-2808. 
Ikeda, M. J., Rahn-Blakeslee, A., Niebling, B. C., Gustafson, J. K., Allison, R., \& Stumme, J. (2007). The Heartland Area Education Agency 11 problem-solving approach: An overview and lessons learned. In S. R. Jimerson, M. K. Burns, \& A. M. VanDerHeyden (Eds.), Handbook of response to intervention: The science and practice of assessment and intervention (pp. 254-268). New York, NY: Springer.

International Reading Association. (IRA, 2010). Response to intervention: Guiding principles for educators from the International Reading Association (Position statement). Newark, DE: Author. Retrieved from http://www.reading.org/Libraries/Resources/RTI_brochure_web.sflb.ashx.

Isaac, S., \& Michael, W. (1997). Handbook in research and evaluation. San Diego: Educational and Industrial Testing Services.

Johnson, E., Mellard, D., Fuchs, D., \& McKnight, M. (2006). Integrating research with improved policies and practices. Retrieved from National Rsearch Center on Learning Disabilities, http://www.nrcld.org/RTI_manual/index.html

Johnston, P. (2010). A framework for resposne to intervention in literacy. In P. E. Johnston, \& P. Johnston (Eds.), RTI in literacy: Responsive and comprehensive (pp. 1-9). Newark, DE: International Reading Association.

Jimerson, S. R., Burns, M. K., \& VanDerHeyden, A. M. (2007). Response to intervention at school: The science and practice of assessment and intervention. In S. R. Jimerson, M. K. Burns, \& A. M. VanDerHeyden (Eds.), Handbook of response to intervention: The science and practice of assessment and intervention (pp. 3-9). New York, NY: Springer. 
Kimmel, M. K. (2008). The successes and challenges of response to intervention: A case study of the impact of RTI implementation. (Doctoral dissertation, University of Southern California, Los Angeles, CA). Retrieved from http://digitallibrary.usc.edu/cdm/ref/collection/p15799coll127/id/46254

Keller-Margulis, M. (2012). Fidelity of implementation framework: A critical need for response to intervention models. Psychology in the Schools, 49(4), 342-352. doi:10.1002/pits.21602.

Klassen, R. M., Usher, E. L., \& Bong, M. (2010). Teachers' collective efficacy, job satisfaction, and job stress in cross-cultural context. Journal of Experimental Education, 78, 464-486. doi: $10.1080 / 00220970903292975$

Kratochwill, T. R., Clements, M. A., \& Kalymon, K. M. (2007). Response to intervention: Conceptual and methodological issues in implementation. In S. R. Jimerson, M. K. Burns, \& A. M. VanDerHeyden (Eds.), Handbook of response to intervention: The science and practice of assessment and intervention (pp. 25-52). New York, NY: Springer.

Leonard, L., \& Leonard, P. (2003, September 17). The continuing trouble with collaboration: Teachers talk. Current Issues in Education [On-line], 6(15). Retrieved from http://cie.ed.asu.edu/volume6/number15/

Lincoln, Y. S., \& Guba, E. G. (1985). Naturalistic inquiry. Beverly Hills, CA: Sage Publications. Lose, M. (2007). A child's respond to intervention requires a responsive teacher of reading. The Reading Teacher, 61(3), 276-279. 
Marston, D., Lau, M., \& Muyskens, P. (2007). Implementation of the problem-solving model in Minneapolis public schools. In S. R. Jimerson, M. K. Burns, \& A. M. VanDerHeyden (Eds.), Handbook of response to intervention: The science and practice of assessment and intervention (pp. 279-287). New York, NY: Springer.

McLaughlin, M. (1989). Listening and learning from the field: Tales of policy implementation and situated practice. In A. Hargreaves, A. Lieberman, M. Fullan, \& D. Hopkins (Eds.), International handbook on educational change (Vol. 1, pp. 70-74). Kluwer Academic Publishers.

McMaster, K. L., \& Wagner, D. (2007). Monitoring response to general education instruction. In S. R. Jimerson, M. K. Burns, \& A. M. VanDerHeyden (Eds.), Handbook of response to intervention: The science and practice of assessment and intervention (pp. 223-233). New York, NY: Springer.

Mellard, D., \& Johnson, E. (2008). RTI: A practicioner's guide to implementing response to intervention. Thousand Oaks, CA: Corwin Press.

Merriam, S. B., \& Associates. (2002). Qualitative research in practice: Examples for discussion and analysis. San Francisco, CA: Jossey-Bass.

Mesmer, E., \& Mesmer, H. (2008). Response to intervention (RTI): What teachers of reading need to know. The Reading Teacher, 62(4), 280-290.

Miles, M. B., \& Huberman, A. M. (1994). Qualitative data analysis: An expanded sourcebook ( $2^{\text {nd }}$ ed.). Thousand Oaks, CA: Sage Publications.

Millhouse-Pettis, E. L. (2011). Response to intervention: Staff perception of the implementation and development of a three-tier model of intervention (Doctoral dissertation, Loyola University, Chicago). Retrieved from http://ecommons.luc.edu/luc_diss/286 
Monaghan, R. (2011). Implementation of response to intervention: How teacher and administrator conceptions reframe district level implementation. (Doctoral dissertation, University of Pennsylvania, Philadelphia, PA). Retrieved from http://search.proquest.com/docview/894254240. (3475836)

Moore, J., \& Whitfield, V. (2009). Building schoolwide capacity for preventing reading failure. The Reading Teacher, 62(7), 622-624.

Munson, A. M. (2013). Federal funding to support response to intervention. Retrieved from http://www.rtinetwork.org/getstarted/develop/federal-funding-to-support-rti

Murakami-Ramalho, E., \& Wilcox, K. (2012). Response to intervention implementation: A successful principal's approach. Journal of Educational Administration, 50(4), 483-500. doi: $10.1108 / 0957823121128602$

Moustakas, C. (1994). Phenomenological research methods. Thousand Oaks, CA: Sage. National Center on Response to Intervention. (2009). RTI state database. Retrieved from National Center on Response to Intervention website: http://state.RTI4success.org/index.php?option=com_chart\&order=ssp\&asc=desc

National Council of Teachers of English. (2009). Standards for the assessment of reading and writing (Revised ed.). Retrieved from http://www.ncte.org/standards/assessmentstandards.

National Research Center on Learning Disabilities. (2006). RTI manual-section 1: School-wide screening. Retrieved from http://www.nrcld.org/RTI_manual/pages/RTIManualSection1.pdf.

Nellis, L. (2012). Maximizing the effectiveness of building teams in response to intervention implementation. Psychology in the Schools, 49(3), 245-256. doi: 10.1002/pits.21594 
Nunn, G. D., \& Jantz, P. B. (2009). Factors within response to intervention implementation training associated with teacher efficacy beliefs. Education, 129, 599-607.

O’Connor, E., \& Freeman, E. (2012). District level considerations in supporting and sustaining RTI implementation. Psychology in the Schools, 49(3), 297-310. doi:10.1002/pits.21598

Palenchar, L., Brown, D., \& Jennings, L. (2006). Response to intervention: An implementation and technical assistance guide for districts and schools. Charleston, WV: West Virginia Department of Education.

Patton, M. Q. (2002). Qualitative research and evaluation methods. Thousand Oaks, CA: Sage Publications.

Peterson, D. W., Prasse, D. P., Shinn, M. R., \& Swerdlik, M. E. (2007). The Illinois flexible service delivery model: A problem-solving model initiative. In S. R. Jimerson, M. K. Burns, \& A. M. VanDerHeyden (Eds.), Handbook of response to intervention: The science and practice of assessment and intervention (pp. 269-278). New York, NY: Springer.

Regional Education Service Agency (RESA ): Regional Education Services Agencies (RESA). (2010). RESA III. Retrieved from http://resa3.k12.wv.us/Docs/About\%20WV\%20RESAs.pdf

Regional Education Service Agency (RESA ): Regional Education Services Agencies (RESA). (2009). RESA 7, Mission and vision. Retrieved from: http://resa7.k12.wv.us/Mission.htm Reutzel, D., \& Mitchell, J. (2005). High-stakes accountabiility themed issue: How did we get here from there? The Reading Teacher, 58(7), 606-608. 
Richardson, V. (1996). The role of attitudes and beliefs in learning to teach. In J. Sikula (Ed.), Handbook of research on teacher education (pp. 102-119). New York: Simon and Shuster.

Rinaldi, C., Baker, D., Averill, O. (2013, August). The nexus of response to intervention (RtI) and the identification of specific learning disabilities (SLD): Guidelines for district-level implementation. Retrieved from Urban Special Education Leadership Collaborative website:

http://www.urbancollaborative.org/sites/urbancollaborative.org/files/nexusbrief.93.final__0.pdf

Risko, V., \& Walker-Dalhouse, D. (2010). Making the most of assessments to inform instruction. The Reading Teacher, 63(5), 420-422.

Shelly, B. (2014). Money, mandates, and local control in American public education. Ann Arbor: University of Michigan Press.

Salkind, N. J. (2004). Statistics for people who think they hate statistics $\left(2^{\text {nd }}\right.$ ed.). Thousand Oaks, CA: Sage Publications.

Sailor, W. (2009). Making RTI work: How smart schools are reforming education through schoolwide response-to-intervention. San Franciso: Jossey-Bass.

Sass, E. (2010). American educational history: A hypertext timeline. Retrieved from http://www.cloudnet.com/ edrbsass/educationhistorytimeline.html

Smith, T., \& Desimone, L. (2005). "Highly qualified" to do what?: The relationship between NCLB teacher quality mandates and the use of reform-oriented instruction in middle school mathematics. Educational Evaluation and Policy Analysis, 27(1), 75-109. 
Stone, C., Orr, M., \& Worgs, D. (2006). The flight of the bumblebee: Why reform is difficult but not impossible. Perspectives on Politics, 4(3), 529-546.

Survey Monkey. (n.d.). Answers and FAQs. Retrieved from http://help.surveymonkey.com/app/answers/categorylist

Torgesen, J. K., Alexander, A. W., Wagner, R. K., Rashotte, C. A., Voeller, K. K., \& Conway, T. (2001). Intensive remedial instruction for children with severe reading disabilities: Immediate and long-term outcomes from two instructional approaches. Journal of Learning Disabilities, 34, 33-58.

Trochim, W. (2006). The Research Methods Knowledge Base, 2nd Edition. Retrieved from http://www.socialresearchmethods.net/kb/

Tucker, J. A., \& Sornson, R. O. (2007). One student at a time; one teacher at a time: Reflections on the use of instructional support. In S. R. Jimerson, M. K. Burns, \& A. M. VanDerHeyden (Eds.), Handbook of response to intervention: The science and practice of assessment and intervention (pp. 269-278). New York, NY: Springer.

Tye, B. B. (2000). Hard truths: Uncovering the deep structure of schooling. New York, NY: Teachers College Press.

U. S. Department of Education. (n.d.). Public Law print of PL 107-110, No Child Left Behind Act. Retrieved from http://www2.ed.gov/policy/elsec/leg/esea02/107-110.pdf.

VanDerHeyden, A. M., \& Burns, M. K. (2010). Essentials of response to intervention. New York: Wiley.

Van Kraayenoord, C. E. (2007). School and classroom practices in inclusive education in Australia. Childhood Education, 83(6), 390-394. 
Vaughn, S., Wanzek, J., Linan-Thompson, S., \& Murray, C. S. (2007). Monitoring response to supplemental services for students at risk for reading difficulties: High and low responders. In S. R. Jimerson, M. K. Burns, \& A. M. VanDerHeyden (Eds.), Handbook of response to intervention: The science and practice of assessment and intervention (pp. 234-243). New York, NY: Springer.

Vellutino, F. R., Scanlon, D. M., \& Zhang, H. (2007). Identifying reading disability based on response to intervention: Evidence from early intervention research. In S. R. Jimerson, M. K. Burns, \& A. M. VanDerHeyden (Eds.), Handbook of response to intervention: The science and practice of assessment and intervention (pp. 185-211). New York, NY: Springer.

Walker-Dalhouse, D., Risko, V., Esworth, C., Grasley. E., Kaisler, G., McIlvain, D., \& Stephan, M. (2009). Crossing boundaries and initiating conversations about RTI: Understanding and applying differentiated classroom instruction. The Reading Teacher, 63(1), 84-87.

Wedl, R. (2005). Response to intervention: An alternative to traditional eligibility criteria for students with disabilities. St. Paul, Minnesota: Hamline University, Center for Policy Studies.

Weishaar, P. M., \& Weishaar, M. K. (2012). Implementing response to intervention in reading within the elementary classroom. Southern Illinois University, Edwardsville: Pearson Paper.

Werts, M., Lambert, M., \& Carpenter, E. (2009). What special education directors say about RTI. Learning Disability Quarterly, 32, 245-254.

West Virginia Department of Education (WVDE). (2005). Response to intervention project, $F A Q$. Retrieved from http://wvde.state.wv.us/osp/FAQforRTI.pdf 
West Virginia Department of Education (WVDE). (2008). District level RTI implementation status rubric. Retrieved from http://wvde.state.wv.us/osp/RTIImplementationStatusRubric.doc.

West Virginia Education Information System. (2009). WVEIS report card. Retrieved from http://wveis.k12.wV.us/nclb/pub/rpt0809/pickreportcard.cfm.

West Virginia Department of Education. (2012). Support for personalized learning: Guidance for West Virginia schools and districts. Charleston, WV: Author. Retrieved from http://wvde.state.wv.us/spl/Documents/spl_guidance_document.pdf

White, R., Polly, D., \& Audette, R. (2012). A case analysis of an elementary school's implementation of response to intervention. Journal of Research in Childhood Education, 26, 73-90. doi: 10/1080/02568543.2011.632067

Wright, J. (2007). RTI toolkit: A practical guide for schools. Port Chester, NY: Dude Publshing. 
APPENDICES 
Appendix A

The State Chart 


\section{Appendix A}

The State Chart

In the State Chart, you can see the answer from all states on these four questions. To sort by question, click on the arrow next to the question. So see more information about a state, click on the state name and you will be taken to that state's page.

\begin{tabular}{|c|c|c|c|c|}
\hline State & $\frac{\begin{array}{c}\text { Does the state } \\
\text { have a State RTI }\end{array}}{\text { Framework? }}$ & $\begin{array}{l}\frac{\text { Does the state }}{\text { have RTI }} \\
\frac{\text { Components in its }}{\text { SPP? }}\end{array}$ & $\begin{array}{c}\begin{array}{c}\text { Does the } \\
\text { state have an }\end{array} \\
\frac{\text { RTI Related }}{\text { SPDG? }}\end{array}$ & $\begin{array}{l}\text { What does the } \\
\frac{\text { state allow for }}{\text { SLD? }}\end{array}$ \\
\hline Alabama & Yes & Yes & Yes & $\begin{array}{l}\text { IQ Discrepancy } \\
\text { \& RTI }\end{array}$ \\
\hline Alaska & Yes & Yes & No & $\begin{array}{l}\text { IQ Discrepancy } \\
\text { \& RTI }\end{array}$ \\
\hline Arizona & Yes & Yes & Yes & $\begin{array}{l}\text { IQ Discrepancy } \\
\text { \& RTI }\end{array}$ \\
\hline Arkansas & Yes & Yes & Yes & $\begin{array}{l}\text { IQ Discrepancy } \\
\text { \& RTI }\end{array}$ \\
\hline California & Yes & Yes & No & $\begin{array}{l}\text { IQ Discrepancy } \\
\text { \& RTI }\end{array}$ \\
\hline$\underline{\text { Colorado }}$ & Yes & Yes & No & RTI Only \\
\hline Connecticut & Yes & Yes & Yes & RTI Only \\
\hline Delaware & Yes & Yes & Yes & $\begin{array}{l}\text { IQ Discrepancy } \\
\text { \& RTI }\end{array}$ \\
\hline$\frac{\text { District Of }}{\text { Columbia }}$ & No & No & Yes & $\begin{array}{l}\text { IQ Discrepancy } \\
\text { \& RTI }\end{array}$ \\
\hline Florida & Yes & Yes & No & $\begin{array}{l}\text { IQ Discrepancy } \\
\text { \& RTI }\end{array}$ \\
\hline Georgia & Yes & Yes & No & $\begin{array}{l}\text { IQ Discrepancy } \\
\text { \& RTI }\end{array}$ \\
\hline Hawaii & Yes & Yes & No & $\begin{array}{l}\text { IQ Discrepancy } \\
\text { \& RTI }\end{array}$ \\
\hline Idaho & Yes & Yes & No & $\begin{array}{l}\text { IQ Discrepancy } \\
\text { \& RTI }\end{array}$ \\
\hline$\underline{\text { Illinois }}$ & Yes & Yes & Yes & $\begin{array}{l}\text { IQ Discrepancy } \\
\text { \& RTI }\end{array}$ \\
\hline$\underline{\text { Indiana }}$ & Yes & Yes & No & RTI Only \\
\hline Iowa & Yes & Yes & Yes & RTI Only \\
\hline
\end{tabular}




\begin{tabular}{|c|c|c|c|c|}
\hline$\underline{\text { State }}$ & $\begin{array}{c}\begin{array}{c}\text { Does the state } \\
\text { have a State RTI }\end{array} \\
\text { Framework? }\end{array}$ & $\begin{array}{l}\frac{\text { Does the state }}{\text { have RTI }} \\
\frac{\text { Components in its }}{\text { SPP? }}\end{array}$ & $\begin{array}{l}\frac{\text { Does the }}{\text { state have an }} \\
\frac{\text { RTI Related }}{\text { SPDG? }}\end{array}$ & $\begin{array}{l}\text { What does the } \\
\frac{\text { state allow for }}{\text { SLD? }}\end{array}$ \\
\hline$\underline{\text { Kansas }}$ & Yes & Yes & Yes & $\begin{array}{l}\text { IQ Discrepancy } \\
\text { \& RTI }\end{array}$ \\
\hline$\underline{\text { Kentucky }}$ & Yes & Yes & Yes & $\begin{array}{l}\text { IQ Discrepancy } \\
\text { \& RTI }\end{array}$ \\
\hline$\underline{\text { Louisiana }}$ & Yes & Yes & Yes & $\begin{array}{l}\text { IQ Discrepancy } \\
\text { \& RTI }\end{array}$ \\
\hline$\underline{\text { Maine }}$ & Yes & No & Yes & $\begin{array}{l}\text { IQ Discrepancy } \\
\text { \& RTI }\end{array}$ \\
\hline$\underline{\text { Maryland }}$ & Yes & Yes & No & $\begin{array}{l}\text { IQ Discrepancy } \\
\text { \& RTI }\end{array}$ \\
\hline$\underline{\text { Massachusetts }}$ & No & Yes & No & $\begin{array}{l}\text { IQ Discrepancy } \\
\text { \& RTI }\end{array}$ \\
\hline$\underline{\text { Michigan }}$ & Yes & Yes & Yes & $\begin{array}{l}\text { IQ Discrepancy } \\
\text { \& RTI }\end{array}$ \\
\hline$\underline{\text { Minnesota }}$ & No & Yes & Yes & $\begin{array}{l}\text { IQ Discrepancy } \\
\text { \& RTI }\end{array}$ \\
\hline$\underline{\text { Mississippi }}$ & Yes & Yes & Yes & $\begin{array}{l}\text { IQ Discrepancy } \\
\text { \& RTI }\end{array}$ \\
\hline$\underline{\text { Missouri }}$ & Yes & Yes & Yes & $\begin{array}{l}\text { IQ Discrepancy } \\
\text { \& RTI }\end{array}$ \\
\hline Montana & Yes & Yes & Yes & $\begin{array}{l}\text { IQ Discrepancy } \\
\text { \& RTI }\end{array}$ \\
\hline$\underline{\text { Nebraska }}$ & Yes & Yes & Yes & $\begin{array}{l}\text { IQ Discrepancy } \\
\text { \& RTI }\end{array}$ \\
\hline$\underline{\text { Nevada }}$ & No & Yes & Yes & $\begin{array}{l}\text { IQ Discrepancy } \\
\text { \& RTI }\end{array}$ \\
\hline$\underline{\text { New }}$ Hampshire & Yes & Yes & Yes & $\begin{array}{l}\text { IQ Discrepancy } \\
\text { \& RTI }\end{array}$ \\
\hline$\underline{\text { New Jersey }}$ & No & Yes & No & $\begin{array}{l}\text { IQ Discrepancy } \\
\text { \& RTI }\end{array}$ \\
\hline$\underline{\text { New Mexico }}$ & Yes & Yes & Yes & $\begin{array}{l}\text { IQ Discrepancy } \\
\text { \& RTI }\end{array}$ \\
\hline$\underline{\text { New York }}$ & Yes & Yes & No & $\begin{array}{l}\text { IQ Discrepancy } \\
\text { \& RTI }\end{array}$ \\
\hline$\underline{\text { North Carolina }}$ & Yes & Yes & Yes & $\begin{array}{l}\text { IQ Discrepancy } \\
\& \text { RTI }\end{array}$ \\
\hline
\end{tabular}




\begin{tabular}{|c|c|c|c|c|}
\hline State & $\begin{array}{c}\begin{array}{c}\text { Does the state } \\
\text { have a State RTI }\end{array} \\
\text { Framework? }\end{array}$ & $\begin{array}{l}\frac{\text { Does the state }}{\text { have RTI }} \\
\frac{\text { Components in its }}{\underline{\text { SPP? }}}\end{array}$ & $\begin{array}{c}\begin{array}{c}\text { Does the } \\
\text { state have an }\end{array} \\
\frac{\text { RTI Related }}{\text { SPDG? }}\end{array}$ & $\begin{array}{l}\text { What does the } \\
\frac{\text { state allow for }}{\underline{\text { SLD? }}}\end{array}$ \\
\hline$\underline{\text { North Dakota }}$ & Yes & Yes & No & $\begin{array}{l}\text { IQ Discrepancy } \\
\text { \& RTI }\end{array}$ \\
\hline$\underline{\text { Ohio }}$ & Yes & Yes & Yes & $\begin{array}{l}\text { IQ Discrepancy } \\
\text { \& RTI }\end{array}$ \\
\hline$\underline{\text { Oklahoma }}$ & No & Yes & Yes & $\begin{array}{l}\text { IQ Discrepancy } \\
\text { \& RTI }\end{array}$ \\
\hline Oregon & Yes & Yes & Yes & $\begin{array}{l}\text { IQ Discrepancy } \\
\text { \& RTI }\end{array}$ \\
\hline $\begin{array}{l}\text { Other } \\
\text { Territories } \\
\end{array}$ & No & No & No & $\begin{array}{l}\text { IQ Discrepancy } \\
\text { \& RTI }\end{array}$ \\
\hline$\underline{\text { Pennsylvania }}$ & Yes & Yes & No & $\begin{array}{l}\text { IQ Discrepancy } \\
\text { \& RTI }\end{array}$ \\
\hline$\underline{\text { Rhode Island }}$ & Yes & Yes & Yes & $\begin{array}{l}\text { IQ Discrepancy } \\
\text { \& RTI }\end{array}$ \\
\hline$\underline{\text { South Carolina }}$ & No & Yes & No & $\begin{array}{l}\text { IQ Discrepancy } \\
\text { \& RTI }\end{array}$ \\
\hline$\underline{\text { South Dakota }}$ & Yes & Yes & No & $\begin{array}{l}\text { IQ Discrepancy } \\
\text { \& RTI }\end{array}$ \\
\hline$\underline{\text { Tennessee }}$ & Yes & Yes & No & $\begin{array}{l}\text { IQ Discrepancy } \\
\text { \& RTI }\end{array}$ \\
\hline$\underline{\text { Texas }}$ & Yes & Yes & No & $\begin{array}{l}\text { IQ Discrepancy } \\
\text { \& RTI }\end{array}$ \\
\hline$\underline{\text { Utah }}$ & Yes & Yes & Yes & $\begin{array}{l}\text { IQ Discrepancy } \\
\text { \& RTI }\end{array}$ \\
\hline Vermont & No & Yes & Yes & $\begin{array}{l}\text { IQ Discrepancy } \\
\text { \& RTI }\end{array}$ \\
\hline$\underline{\text { Virginia }}$ & Yes & Yes & No & $\begin{array}{l}\text { IQ Discrepancy } \\
\text { \& RTI }\end{array}$ \\
\hline Washington & Yes & Yes & Yes & $\begin{array}{l}\text { IQ Discrepancy } \\
\text { \& RTI }\end{array}$ \\
\hline$\underline{\text { West Virginia }}$ & Yes & Yes & Yes & $\begin{array}{l}\text { IQ Discrepancy } \\
\text { \& RTI }\end{array}$ \\
\hline$\underline{\text { Wisconsin }}$ & Yes & Yes & Yes & $\begin{array}{l}\text { IQ Discrepancy } \\
\text { \& RTI }\end{array}$ \\
\hline Wyoming & Yes & Yes & Yes & $\begin{array}{l}\text { IQ Discrepancy } \\
\text { \& RTI }\end{array}$ \\
\hline & & & \multicolumn{2}{|c|}{ (C) Copyright 2009} \\
\hline
\end{tabular}


Appendix B

Survey 


\section{Appendix B}

\section{Survey}

1. What parties are responsible for the delivery of intervention in
a. Tier I -
b. Tier II -
c. Tier III -

2. What core reading program is used for instruction in Tier I?

3. What programs (Wilson, Fundations, Voyager, etc.) are used to deliver instruction in
d. Tier II -
e. Tier III -

4. What programs do you use for:

f. initial screening

g. progress monitoring

5. How much time do you spend daily providing intervention? 
6. Please rate the following statements regarding the currently level of implementation of RTI at your school (Classroom Teachers, Special Educators, Title I Teachers, and Principals) or county (Literacy Coaches/County Level Administration)

\section{INSTRUCTION}

\begin{tabular}{|c|c|c|c|c|c|}
\hline & Not In Place & Emerging & $\begin{array}{c}\text { Making } \\
\text { Progress }\end{array}$ & Established & $\mathrm{N} / \mathrm{A}$ \\
\hline $\begin{array}{l}\text { a. Tier I instruction } \\
\text { includes } \\
\text { differentiated, } \\
\text { small group work. }\end{array}$ & $C$ & $C$ & $C$ & $C$ & $C$ \\
\hline $\begin{array}{l}\text { b. Tier II } \\
\text { intervention is } \\
\text { provided for } 30 \\
\text { minutes daily } \\
\text { beyond the } \\
\text { required Reading } \\
\text { block. }\end{array}$ & $C$ & $C$ & $C$ & $C$ & $C$ \\
\hline $\begin{array}{l}\text { c. Tier III is } \\
\text { provided for } 45-60 \\
\text { minutes daily } \\
\text { beyond the } \\
\text { required Reading } \\
\text { block and utilizes a } \\
\text { research-based } \\
\text { reading } \\
\text { intervention } \\
\text { program. }\end{array}$ & $C$ & $C$ & $C$ & $C$ & $c$ \\
\hline $\begin{array}{l}\mathrm{d} \text {. Teachers have } \\
\text { received instruction } \\
\text { on strengthening } \\
\text { Tier } 1 \text { instruction } \\
\text { in reading and have } \\
\text { become familiar } \\
\text { with Tiered Models } \\
\text { and intervention } \\
\text { language. }\end{array}$ & $C$ & 0 & $C$ & $C$ & 6 \\
\hline
\end{tabular}


7. Please rate the following statements regarding the current level of implementation of RTI at your school (Classroom Teachers, Special Educators, Title I Teachers, and Principals) or county (Literacy Coaches/County Level Administration).

RESPONSIVE TEACHING AND DIFFERENTIATION

\begin{tabular}{|c|c|c|c|c|c|}
\hline & Not In Place & Emerging & $\begin{array}{c}\text { Making } \\
\text { Progress }\end{array}$ & Established & $\mathrm{N} / \mathrm{A}$ \\
\hline $\begin{array}{l}\text { a. The master } \\
\text { schedule includes } \\
\text { Policy } 2510 \text { time } \\
\text { requirements for } \\
\text { Reading/Language } \\
\text { Arts. }\end{array}$ & $C$ & $\mathrm{C}$ & $C$ & $C$ & 0 \\
\hline $\begin{array}{l}\text { b. Intervention } \\
\text { blocks are clearly } \\
\text { designated in the } \\
\text { master school } \\
\text { schedule. }\end{array}$ & $C$ & $\mathrm{C}$ & $C$ & $C$ & 0 \\
\hline $\begin{array}{l}\text { c. Tier II } \\
\text { intervention group } \\
\text { size is 3-5students } \\
\text { per interventionist. }\end{array}$ & $C$ & $C$ & $C$ & $C$ & 0 \\
\hline $\begin{array}{l}\text { d. Tier III } \\
\text { intervention group } \\
\text { size is 1-3 students } \\
\text { per interventionist. }\end{array}$ & $C$ & 0 & $C$ & $C$ & 0 \\
\hline $\begin{array}{l}\text { e. Teachers have } \\
\text { been provided } \\
\text { dedicated time to } \\
\text { analyze data and } \\
\text { plan } \\
\text { collaboratively }\end{array}$ & $C$ & 0 & $C$ & $C$ & 0 \\
\hline $\begin{array}{l}\text { f. Teachers have } \\
\text { been included in } \\
\text { the selection of a } \\
\text { model for } \\
\text { delivering } \\
\text { intervention that } \\
\text { delineates } \\
\text { personnel, } \\
\text { schedules, and } \\
\text { instructional spaces }\end{array}$ & $C$ & 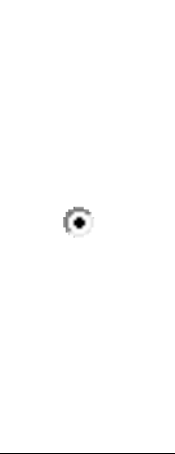 & 0 & $C$ & 0 \\
\hline
\end{tabular}


8. Please rate the following statements regarding the current level of implementation of RTI at your school (Classroom Teachers, Special Educators, Title I Teachers, and Principals) or county (Literacy Coaches/County Level Administration).

\section{ASSESSMENT}

\begin{tabular}{|c|c|c|c|c|c|}
\hline & Not In Place & Emerging & $\begin{array}{c}\text { Making } \\
\text { Progress }\end{array}$ & Established & N/A \\
\hline $\begin{array}{l}\text { a. Universal } \\
\text { screening occurs } 3 \\
\text { times a year. }\end{array}$ & $C$ & $C$ & $C$ & $C$ & $c$ \\
\hline $\begin{array}{l}\text { b. Progress } \\
\text { monitoring takes } \\
\text { place at least every } \\
\text { two weeks. }\end{array}$ & $C$ & $\mathrm{C}$ & $C$ & $C$ & 0 \\
\hline $\begin{array}{l}\text { c. Diagnostic } \\
\text { testing is } \\
\text { conducted } \\
\text { regularly to } \\
\text { pinpoint specific } \\
\text { skill deficiencies. }\end{array}$ & $C$ & 0 & $C$ & $C$ & 0 \\
\hline $\begin{array}{l}\text { d. Our school has a } \\
\text { data system in } \\
\text { place for both } \\
\text { progress } \\
\text { monitoring and } \\
\text { benchmark } \\
\text { assessments. }\end{array}$ & $C$ & $C$ & 0 & $C$ & 0 \\
\hline $\begin{array}{l}\text { e. Teachers follow } \\
\text { a predetermined } \\
\text { schedule for } \\
\text { benchmark and } \\
\text { progress } \\
\text { monitoring } \\
\text { assessments }\end{array}$ & $\mathrm{C}$ & $C$ & $C$ & $C$ & $C$ \\
\hline $\begin{array}{l}\text { f. Teachers have } \\
\text { developed } \\
\text { strategies for } \\
\text { monitoring } \\
\text { implementation of } \\
\text { research-based } \\
\text { reading strategies. }\end{array}$ & $C$ & $C$ & 0 & 0 & 0 \\
\hline
\end{tabular}


9. Please rate the following statements regarding the current level of implementation of RTI at your school (Classroom Teachers, Special Educators, Title I Teachers, and Principals) or county (Literacy Coaches/County Level Administration).

\section{COLLABORATION}

\begin{tabular}{|c|c|c|c|c|c|}
\hline & Not In Place & Emerging & $\begin{array}{c}\text { Making } \\
\text { Progress }\end{array}$ & Established & $\mathrm{N} / \mathrm{A}$ \\
\hline $\begin{array}{l}\text { a. Grade Level } \\
\text { teams have } \\
\text { common and } \\
\text { adequate planning } \\
\text { times for data } \\
\text { analysis and } \\
\text { problem solving. }\end{array}$ & $C$ & $C$ & $C$ & $C$ & 0 \\
\hline $\begin{array}{l}\text { b. General } \\
\text { education teachers, } \\
\text { Title I teachers, } \\
\text { Special Educators, } \\
\text { LEP teachers and } \\
\text { other } \\
\text { interventionists } \\
\text { share } \\
\text { responsibilities for } \\
\text { instruction and } \\
\text { intervention. }\end{array}$ & 0 & $C$ & $C$ & $C$ & 0 \\
\hline $\begin{array}{l}\text { c. Staff focuses on } \\
\text { problem solving } \\
\text { and adjusting } \\
\text { instruction rather } \\
\text { than simply } \\
\text { referring students } \\
\text { to special } \\
\text { education. }\end{array}$ & $C$ & $C$ & $C$ & $C$ & $c$ \\
\hline $\begin{array}{l}\text { d. Instruction and } \\
\text { Intervention Teams } \\
\text { or Student } \\
\text { Assistance Teams } \\
\text { (SATs) work to } \\
\text { make decisions } \\
\text { such as movement } \\
\text { among tiers, need } \\
\text { for additional } \\
\text { resources, and } \\
\text { referral to SAT. }\end{array}$ & $C$ & $c$ & $C$ & $C$ & $\mathrm{C}$ \\
\hline $\begin{array}{l}\text { e. Eligibility } \\
\text { Committees (ECs) } \\
\text { are trained in } \\
\text { making eligibility }\end{array}$ & $\mathrm{C}$ & $c$ & $\mathrm{C}$ & $C$ & $c$ \\
\hline
\end{tabular}




\begin{tabular}{|c|c|c|c|c|c|}
\hline & Not In Place & Emerging & $\begin{array}{c}\text { Making } \\
\text { Progress }\end{array}$ & Established & N/A \\
\hline $\begin{array}{l}\text { decisions using } \\
\text { RTI procedures for } \\
\text { identification of } \\
\text { students with } \\
\text { specific learning } \\
\text { disabilities }\end{array}$ & & & & & \\
\hline $\begin{array}{l}\text { f. ECs have } \\
\text { received } \\
\text { information about } \\
\text { how to } \\
\text { communicate with } \\
\text { parents about the 3- } \\
\text { Tier instructional } \\
\text { model }\end{array}$ & $C$ & $C$ & $C$ & $C$ & 0 \\
\hline $\begin{array}{l}\text { g. ECs have been } \\
\text { involved in the } \\
\text { develop of a master } \\
\text { school schedule to } \\
\text { include capacity } \\
\text { for Tier } 2 \text { and Tier } \\
3 \text { interventions }\end{array}$ & $C$ & 0 & $C$ & $C$ & 0 \\
\hline $\begin{array}{l}\text { h. ECs have } \\
\text { assisted in the } \\
\text { arrangement of } \\
\text { staffing to provide } \\
\text { Tier } 2 \text { and Tier } 3 \\
\text { interventions }\end{array}$ & $C$ & $\mathrm{C}$ & $\mathrm{C}$ & 0 & 0 \\
\hline
\end{tabular}


10. Please rate the following statements regarding the current level of implementation of RTI at your school (Classroom Teachers, Special Educators, Title I Teachers, and Principals) or county (Literacy Coaches/County Level Administration).

SYSTEMIC AND COMPREHENSIVE APPROACHES

\begin{tabular}{|c|c|c|c|c|c|}
\hline & Not In Place & Emerging & Making Progress & Established & N/A \\
\hline $\begin{array}{l}\text { a. Teachers are } \\
\text { trained on how to } \\
\text { deliver the core } \\
\text { reading program } \\
\text { with fidelity. }\end{array}$ & $\mathrm{C}$ & $\mathrm{C}$ & $C$ & $C$ & $\mathrm{c}$ \\
\hline $\begin{array}{l}\text { b. Teachers are } \\
\text { trained on data } \\
\text { analysis for } \\
\text { instructional } \\
\text { decision-making. }\end{array}$ & $\mathrm{C}$ & $\mathrm{C}$ & $\mathrm{C}$ & 0 & $c$ \\
\hline $\begin{array}{l}\text { c. Teachers are } \\
\text { trained on explicit, } \\
\text { systematic } \\
\text { intervention } \\
\text { planning and } \\
\text { delivery including, } \\
\text { as appropriate, } \\
\text { research-based } \\
\text { reading } \\
\text { intervention } \\
\text { programs. }\end{array}$ & $\mathrm{C}$ & $\mathrm{C}$ & $\mathrm{C}$ & $C$ & $\mathrm{C}$ \\
\hline $\begin{array}{l}\text { d. School-level } \\
\text { professional } \\
\text { development } \\
\text { includes job- } \\
\text { embedded } \\
\text { components such } \\
\text { as professional } \\
\text { learning } \\
\text { communities } \\
\text { and/or instructional } \\
\text { coaching. }\end{array}$ & $\mathrm{C}$ & $C$ & $C$ & 0 & $\mathrm{C}$ \\
\hline $\begin{array}{l}\text { e. Teachers have } \\
\text { received } \\
\text { professional } \\
\text { development in } \\
\text { establishing the } \\
\text { components of a 3- } \\
\text { tier model. }\end{array}$ & $\mathrm{C}$ & 0 & $\mathrm{C}$ & 0 & 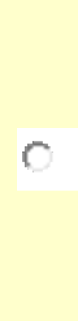 \\
\hline $\begin{array}{l}\text { f. Teachers have } \\
\text { assisted with the } \\
\text { determination of }\end{array}$ & $\mathrm{C}$ & $C$ & $C$ & $c$ & $c$ \\
\hline
\end{tabular}




\begin{tabular}{|l|c|c|c|c|c|}
\hline & Not In Place & Emerging & Making Progress & Established & N/A \\
\hline $\begin{array}{l}\text { which personnel } \\
\text { will administer } \\
\text { assessments. }\end{array}$ & & & & & \\
\hline $\begin{array}{l}\text { g. Teachers have } \\
\text { received } \\
\text { professional } \\
\text { development for } \\
\text { special education } \\
\text { and Title 1 teachers } \\
\text { in designing and } \\
\text { delivering } \\
\text { interventions. }\end{array}$ & & & & & \\
\hline
\end{tabular}


11. Please rate the following statements regarding the current level of implementation of RTI at your school (Classroom Teachers, Special Educators, Title I Teachers, and Principals) or county (Literacy Coaches/County Level Administration).

\section{EXPERTISE}

\begin{tabular}{|c|c|c|c|c|c|}
\hline & Not In Place & Emerging & $\begin{array}{c}\text { Making } \\
\text { Progress }\end{array}$ & Established & N/A \\
\hline $\begin{array}{l}\text { a. School } \\
\text { Assistance Team } \\
\text { (SATs) understand } \\
\text { RtI data collection } \\
\text { requirements for } \\
\text { special education } \\
\text { referrals. }\end{array}$ & $C$ & $C$ & $C$ & $C$ & $\mathrm{C}$ \\
\hline $\begin{array}{l}\text { b. The school } \\
\text { psychologist is } \\
\text { trained in RtI } \\
\text { procedures for } \\
\text { designing multi- } \\
\text { disciplinary } \\
\text { evaluations. }\end{array}$ & $C$ & $C$ & $C$ & $C$ & $C$ \\
\hline $\begin{array}{l}\text { c. Teachers have } \\
\text { received training in } \\
\text { data analysis, } \\
\text { grouping students } \\
\text { for intervention, } \\
\text { and intervention } \\
\text { lesson planning. }\end{array}$ & $C$ & 0 & $C$ & $C$ & 0 \\
\hline $\begin{array}{l}\text { d. Teachers have } \\
\text { been introduced to } \\
\text { tiered instruction } \\
\text { and integration } \\
\text { with West Virginia } \\
\text { Content Standards } \\
\text { and Objectives. }\end{array}$ & $C$ & $C$ & 0 & $C$ & 0 \\
\hline $\begin{array}{l}\text { e. Teachers have } \\
\text { been involved in } \\
\text { professional } \\
\text { learning } \\
\text { communities } \\
\text { regarding delivery } \\
\text { of intervention. }\end{array}$ & $C$ & 0 & $\mathrm{C}$ & 0 & 0 \\
\hline
\end{tabular}


12. What barriers has your school encountered with the RtI implementation process?

13. Please describe the criteria that are used in your school to determine if a student should be moved to a more intensive tier of support (e.g., number of weeks of intervention, special education testing, etc.).

14. Please provide any additional comments about RtI that you feel would be beneficial to planning for future implementation.

15. What is your current position?

\begin{tabular}{|l|c|}
\hline & Select all that apply. \\
\hline Paraprofessional & $\Gamma$ \\
\hline Classroom Teacher & $\Gamma$ \\
\hline Reading Specialist & $\Gamma$ \\
\hline $\begin{array}{l}\text { Special Education } \\
\text { Teacher }\end{array}$ & $\Gamma$ \\
\hline Principal & $\Gamma$ \\
\hline $\begin{array}{l}\text { Assistant } \\
\text { Superintendent for } \\
\text { Curriculum \& } \\
\text { Instruction }\end{array}$ & $\Gamma$ \\
\hline $\begin{array}{l}\text { Special Education } \\
\text { Director }\end{array}$ & $\Gamma$ \\
\hline $\begin{array}{l}\text { Director of Federal } \\
\text { Programs }\end{array}$ & $\Gamma$ \\
\hline $\begin{array}{l}\text { Curriculum } \\
\text { Director }\end{array}$ & $\Gamma$ \\
\hline Title I Director & $\Gamma$ \\
\hline Superintendent & $\Gamma$ \\
\hline
\end{tabular}


16. What level do you predominantly teach in your current position?

\begin{tabular}{|c|c|c|c|c|c|c|c|c|c|c|c|}
\hline & Pre-K & $\mathrm{K}$ & 1 & 2 & 3 & 4 & 5 & 6 & 7 & 8 & 9 \\
\hline Elementary & $\Gamma$ & $\Gamma$ & $\Gamma$ & Г & Г & $\Gamma$ & $\Gamma$ & $\Gamma$ & $\Gamma$ & Г & $\Gamma$ \\
\hline Middle & $\Gamma$ & $\Gamma$ & $\Gamma$ & $\Gamma$ & $\Gamma$ & $\Gamma$ & $\Gamma$ & $\Gamma$ & $\Gamma$ & $\Gamma$ & $\Gamma$ \\
\hline
\end{tabular}

17. How many years experience do you have in the teaching profession?

\begin{tabular}{|l|c|}
\hline & Please choose one. \\
\hline $0-5$ years & $\Gamma$ \\
\hline $6-10$ years & $\Gamma$ \\
\hline $11-15$ years & $\Gamma$ \\
\hline $16-20$ years & $\Gamma$ \\
\hline $20-25$ years & $\Gamma$ \\
\hline $25+$ years & $\Gamma$ \\
\hline
\end{tabular}

18. What is your degree level?

$\ulcorner\quad$ Bachelor's Degree
$\ulcorner\quad$ Master's Degree
$\ulcorner\quad$ Doctorate Degree
$\ulcorner\quad$ Education Specialist Degree
Other (please specify)

19. Please indicate the institution from which your degree(s) were conferred

\begin{tabular}{|l|c|}
\hline & Institutions \\
\hline Bachelor's Degree & \multicolumn{1}{|}{} \\
\hline Master's Degree & \multicolumn{1}{|}{} \\
\hline Doctorate Degree & \multicolumn{1}{|}{} \\
\hline
\end{tabular}

Other Institution 
20. Please choose the level(s) you are certified to teach and list certification area(s).

$\begin{array}{ll}\ulcorner & \text { K-6 } \\ \ulcorner & \text { K-5 } \\ \Gamma & 1-5 \\ \Gamma & 1-6 \\ \Gamma & \text { PreK-6 } \\ \Gamma & \text { Pre-K } \\ \Gamma & 5-9 \\ \Gamma & 6-8 \\ \Gamma & 6-9 \\ \Gamma & 5-12 \\ \Gamma & 6-12 \\ \Gamma & \text { PreK-12 } \\ \Gamma & \text { Pre-K-Adult } \\ \Gamma & 5-\text { Adult }\end{array}$

Certification Area(s)/Minor(s)

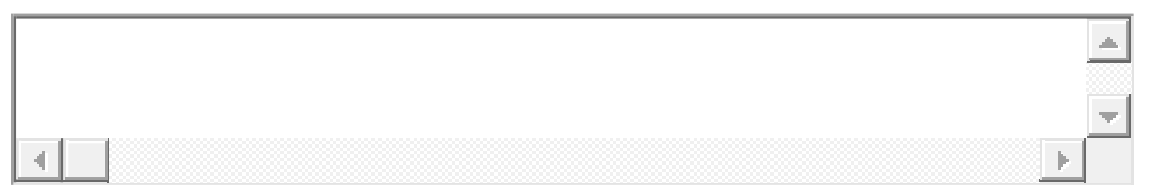

21. Please indicate your age range
ए 22-27
Г 28-32
Г $33-37$
Г 38-42
Г 43-47
Г 48-52
Г 53-57
Г 58-62
Г $62+$ 
22. What is your current county of employment?

\section{$\Gamma \quad$ Preston \\ $\ulcorner$ Randolph \\ $\lceil$ Upshur}

If you would be interested in participating in a brief interview, please contact the researcher via email at tsamples@mix.wvu.edu. 
Appendix C

Response to the Intervention Checklist 


\section{Appendix C \\ Response to Intervention Implementation Checklist}

\section{Response to Intervention is an instructional framework designed to meet students' needs through tiered instruction. Its goals are to ensure that all students struggling in reading, writing and mathematics receive instructional supports designed to address specific needs and ensure access to rigorous $21^{\text {st }}$ century instruction.}

1. Conduct professional development in establishing the components of a 3-tier model

2. Strengthen Tier 1 instruction in reading and math and become familiar with Tiered Models and intervention language

3. Train teachers in data analysis, grouping students for intervention, and intervention lesson planning

4. Provide designated time for teachers to analyze data and plan collaboratively

5. Select a model for delivering intervention that delineates personnel, schedules, and instructional spaces

6. Communicate with parents about the 3-Tier instructional model

7. Develop master school schedule to include capacity for Tier 2 and Tier 3 interventions

8. Develop school-wide assessment calendar for benchmark and progress monitoring

9. Determine which personnel will administer assessments

10. Implement universal screening in September, January, and May

11. Provide professional development for special education and Title 1 teachers in designing and delivering interventions

12. Arrange staffing to provide Tier 2 and Tier 3 interventions

13. Develop strategies for monitoring implementation of research-based reading and mathematics strategies (e.g., Principal walk-throughs)

14. Introduce tiered instruction and integration with WV CSOs to grade 3-5 teachers

15. Establish professional learning communities for Grades 3-5 teachers regarding delivery of intervention

16. Assemble administrator's data notebook (e.g., school-wide data reports, data summaries by class and grade levels) 
Appendix D

District Level Implementation Status Rubric 


\section{Appendix D}

\section{District Level Implementation Status Rubric}

\begin{tabular}{|c|c|c|c|c|}
\hline & Not in Place & Emerging & Making Progress & Established \\
\hline Assessment & $\begin{array}{l}\text { No schools have } \\
\text { universal } \\
\text { screening and } \\
\text { progress } \\
\text { monitoring tools } \\
\text { in place }\end{array}$ & $\begin{array}{l}\text { Some schools have } \\
\text { universal and progress } \\
\text { monitoring tools in } \\
\text { place and/or data } \\
\text { analysis for grouping } \\
\text { and intervention may } \\
\text { or may not be in place }\end{array}$ & $\begin{array}{l}\text { Most schools have } \\
\text { universal and progress } \\
\text { monitoring tools in place } \\
\text { and demonstrate some } \\
\text { competency in data } \\
\text { analysis for grouping and } \\
\text { intervention }\end{array}$ & $\begin{array}{l}\text { All schools have universal and } \\
\text { progress monitoring tools in } \\
\text { place and demonstrate } \\
\text { competency in data analysis for } \\
\text { grouping and intervention }\end{array}$ \\
\hline Instruction & $\begin{array}{l}3 \text {-tier reading } \\
\text { model for reading } \\
\text { is not in place }\end{array}$ & $\begin{array}{l}\text { 3-tier reading model is } \\
\text { lacking more than one } \\
\text { component (e.g., } \\
\text { strong Tier } 1 \text {, } \\
\text { intervention scheduled } \\
\text { and delivered, } \\
\text { designated Tier } 2 \\
\text { program/methods) }\end{array}$ & $\begin{array}{l}\text { 3-tier reading model is } \\
\text { implemented in schools } \\
\text { but continues to need } \\
\text { refinement (e.g., } \\
\text { personnel needs, training } \\
\text { needs, scheduling issues) }\end{array}$ & $\begin{array}{l}\text { 3-tier reading model is in place } \\
\text { with fidelity (all components } \\
\text { established) }\end{array}$ \\
\hline $\begin{array}{l}\text { Collaboration } \\
\text { \& Problem } \\
\text { Solving }\end{array}$ & $\begin{array}{l}\text { No schools } \\
\text { provide time for } \\
\text { grade level } \\
\text { collaboration }\end{array}$ & $\begin{array}{l}\text { Some schools provide } \\
\text { time for grade level } \\
\text { collaboration }\end{array}$ & $\begin{array}{l}\text { Most schools provide } \\
\text { time for grade level } \\
\text { collaboration }\end{array}$ & $\begin{array}{l}\text { All schools provide time for } \\
\text { grade level collaboration }\end{array}$ \\
\hline $\begin{array}{l}\text { Professional } \\
\text { Development }\end{array}$ & $\begin{array}{l}\text { No professional } \\
\text { development on } \\
\text { RTI has been } \\
\text { provided to } \\
\text { teachers and } \\
\text { administrators at } \\
\text { the district/school } \\
\text { level }\end{array}$ & $\begin{array}{l}\text { Teachers and } \\
\text { principals have } \\
\text { participated in some } \\
\text { district or state level } \\
\text { trainings on RTI (e.g., } \\
\text { K-3 Reading Model } \\
\text { Training and Follow- } \\
\text { up) }\end{array}$ & $\begin{array}{l}\text { District has offered } \\
\text { professional development } \\
\text { on RTI to all teachers and } \\
\text { administrators (e.g., } \\
\text { principals' meetings, } \\
\text { district summer institutes, } \\
\text { coaching.) }\end{array}$ & $\begin{array}{l}\text { A district-level professional } \\
\text { development plan for RTI } \\
\text { implementation has been } \\
\text { created and is in progress }\end{array}$ \\
\hline $\begin{array}{c}\text { Special } \\
\text { Education } \\
\text { Referral \& } \\
\text { Eligibility } \\
\text { Procedures }\end{array}$ & $\begin{array}{l}\text { All appropriate } \\
\text { staff are not } \\
\text { involved in RTI } \\
\text { decision-making } \\
\text { processes for SAT } \\
\text { and are not aware } \\
\text { of the data } \\
\text { collection } \\
\text { requirements for } \\
\text { SLD eligibility }\end{array}$ & $\begin{array}{l}\text { All appropriate staff } \\
\text { participate in school } \\
\text { level collaboration } \\
\text { meetings understand } \\
\text { the decision-making } \\
\text { processes for SAT but } \\
\text { are just beginning to } \\
\text { meet/follow data } \\
\text { collection } \\
\text { requirements for SLD } \\
\text { eligibility }\end{array}$ & $\begin{array}{l}\text { All appropriate staff } \\
\text { participate in school level } \\
\text { collaboration meetings, } \\
\text { understand the decision- } \\
\text { making processes for } \\
\text { SAT and meet/follow } \\
\text { data collection } \\
\text { requirements for SLD } \\
\text { eligibility }\end{array}$ & $\begin{array}{l}\text { Appropriate staff participate in } \\
\text { school level collaboration } \\
\text { meetings, understand the } \\
\text { decision-making processes for } \\
\text { SAT and meet/follow data } \\
\text { collection requirements for } \\
\text { SLD eligibility }\end{array}$ \\
\hline
\end{tabular}


Appendix E

School Readiness for RTI: A Self-Assessment 


\section{Appendix E}

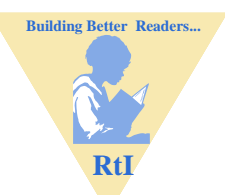

\begin{tabular}{|c|c|c|c|c|}
\hline Indicators of School Readiness & $\begin{array}{l}\text { Not in } \\
\text { place }\end{array}$ & $\begin{array}{l}\text { Starting to } \\
\text { move in } \\
\text { this } \\
\text { direction }\end{array}$ & $\begin{array}{c}\text { Making } \\
\text { good } \\
\text { progress } \\
\text { here }\end{array}$ & $\begin{array}{l}\text { Well } \\
\text { established } \\
\text { practice }\end{array}$ \\
\hline \multicolumn{5}{|l|}{$\begin{array}{l}\text { 1. Grade Level Teaming and Student Assistance } \\
\text { Team (SAT) Structures }\end{array}$} \\
\hline \multicolumn{5}{|l|}{$\begin{array}{l}\text { a. Use of problem solving and data driven } \\
\text { decision making processes }\end{array}$} \\
\hline \multicolumn{5}{|l|}{$\begin{array}{l}\text { b. Focus on problem solving rather than special } \\
\text { education referrals }\end{array}$} \\
\hline \multicolumn{5}{|l|}{$\begin{array}{l}\text { c. Focus on intervention rather than } \\
\text { accommodations }\end{array}$} \\
\hline \multicolumn{5}{|l|}{$\begin{array}{l}\text { d. Same grade level teachers have common } \\
\text { planning time for data analysis and problem } \\
\text { solving }\end{array}$} \\
\hline \multicolumn{5}{|l|}{$\begin{array}{l}\text { e. Shared responsibility and collaboration among } \\
\text { general educators and program specialists } \\
\text { (e.g., special education, Title 1, ESL) }\end{array}$} \\
\hline \multicolumn{5}{|l|}{$\begin{array}{l}\text { 2. High Quality Core Reading Instruction in } \\
\text { General Education }\end{array}$} \\
\hline \multicolumn{5}{|l|}{$\begin{array}{l}\text { a. Core program addresses } 5 \text { components } \\
\text { (phonemic awareness, phonics, fluency, } \\
\text { vocabulary and comprehension) in an explicit, } \\
\text { systematic manner }\end{array}$} \\
\hline \multicolumn{5}{|l|}{$\begin{array}{l}\text { b. Core program is research-based and taught } \\
\text { with fidelity (i.e., teachers teach the program } \\
\text { as intended by publisher in order to maximize } \\
\text { effectiveness) }\end{array}$} \\
\hline \multicolumn{5}{|l|}{$\begin{array}{l}\text { c. Staff is willing to evaluate its existing core } \\
\text { program to determine adequacy and work to } \\
\text { supplement any deficiencies }\end{array}$} \\
\hline \multicolumn{5}{|l|}{$\begin{array}{l}\text { 3. Screening, Assessment and Progress } \\
\text { Monitoring Practices and Procedures }\end{array}$} \\
\hline \multicolumn{5}{|l|}{$\begin{array}{l}\text { a. Universal screening system to measure and } \\
\text { monitor the development of pre-reading and } \\
\text { early reading skills }\end{array}$} \\
\hline $\begin{array}{l}\text { b. Progress monitoring is systematic, documented } \\
\text { and shared among staff }\end{array}$ & & & & \\
\hline
\end{tabular}

West Virginia Response to Intervention Project

School Readiness for Response to Intervention (RtI): A Self-Assessment

Level of Implementation: 


\begin{tabular}{|c|c|c|c|c|}
\hline Indicators of School Readiness & $\begin{array}{c}\text { Not in } \\
\text { place }\end{array}$ & $\begin{array}{l}\text { Starting to } \\
\text { move in } \\
\text { this } \\
\text { direction }\end{array}$ & $\begin{array}{c}\text { Making } \\
\text { good } \\
\text { progress } \\
\text { here }\end{array}$ & $\begin{array}{l}\text { Well } \\
\text { established } \\
\text { practice }\end{array}$ \\
\hline $\begin{array}{l}\text { c. A data management system is in place and } \\
\text { technology support is available at the school } \\
\text { and/or district level }\end{array}$ & & & & \\
\hline \multicolumn{5}{|l|}{ 4. Leadership \& Program Capacity } \\
\hline \multicolumn{5}{|l|}{$\begin{array}{l}\text { a. Strong instructional leader to organize and } \\
\text { guide the development of RtI within the } \\
\text { context of the total school }\end{array}$} \\
\hline \multicolumn{5}{|l|}{ b. Personnel available to collect and analyze data } \\
\hline \multicolumn{5}{|l|}{$\begin{array}{l}\text { c. Personnel available to provide small group } \\
\text { instruction and intervention at Tiers 1-3 in } \\
\text { grades K-3 }\end{array}$} \\
\hline \multicolumn{5}{|l|}{$\begin{array}{l}\text { d. School psychologist trained in RtI procedures } \\
\text { to coordinate evaluation/eligibility processes }\end{array}$} \\
\hline \multicolumn{5}{|l|}{ e. Instructional materials/programs are available } \\
\hline \multicolumn{5}{|l|}{$\begin{array}{l}\text { f. System in place to evaluate research-based } \\
\text { interventions as to integrity/fidelity of } \\
\text { implementation (e.g., School curriculum team, } \\
\text { district Title } 1 \text { personnel, etc.) }\end{array}$} \\
\hline \multicolumn{5}{|l|}{$\begin{array}{l}\text { 5. Professional Development to Address Relevant } \\
\text { Areas }\end{array}$} \\
\hline \multicolumn{5}{|l|}{$\begin{array}{l}\text { a. Professional development addresses the } 5 \\
\text { components of reading instruction }\end{array}$} \\
\hline \multicolumn{5}{|l|}{$\begin{array}{l}\text { b. Professional development includes } \\
\text { effective use of data, including that } \\
\text { obtained from progress monitoring, in } \\
\text { making instructional decisions }\end{array}$} \\
\hline \multicolumn{5}{|l|}{$\begin{array}{l}\text { c. Professional development addresses } \\
\text { research-based interventions }\end{array}$} \\
\hline \multicolumn{5}{|l|}{$\begin{array}{l}\text { d. Professional development includes job- } \\
\text { embedded components such as coaching, } \\
\text { professional dialogue, peer feedback, etc. }\end{array}$} \\
\hline $\begin{array}{l}\text { e. Professional development includes a parent } \\
\text { engagement component }\end{array}$ & & & & \\
\hline
\end{tabular}

The School Readiness for RtI: A Self-Assessment was adapted with permission from the Colorado Department of Education. 
Appendix F

Response to Intervention Process: Implementation Status Report at Elementary Level 


\begin{abstract}
Appendix F
Response to Intervention Process: Implementation Status Report at Elementary Level

Grade Configuration (e.g.,

K-4):
\end{abstract}

School:

PART I: Please rate your school's level of RTI implementation in the area of Reading at each set of grade levels using the following rating system:

0 - Not yet in place

1 - Emerging

2 - Making Progress

\begin{tabular}{|c|c|c|c|}
\hline RTI INSTRUCTIONAL FRAMEWORK COMPONENTS & K-2 & 3-4 & $5-6$ \\
\hline \multicolumn{4}{|l|}{ ASSESSMENT } \\
\hline \multicolumn{4}{|l|}{ Universal screening 3 times per year to measure skill development } \\
\hline \multicolumn{4}{|l|}{$\begin{array}{l}\text { Progress monitoring at least every two weeks for students receiving } \\
\text { intervention }\end{array}$} \\
\hline \multicolumn{4}{|l|}{ Diagnostic testing to pinpoint specific skills deficiencies } \\
\hline \multicolumn{4}{|l|}{ Data management system in place and technology support available } \\
\hline \multicolumn{4}{|l|}{ INSTRUCTION } \\
\hline \multicolumn{4}{|l|}{$\begin{array}{l}\text { Master schedule includes Policy } 2510 \text { time requirements for Reading/English } \\
\text { Language Arts }\end{array}$} \\
\hline \multicolumn{4}{|l|}{$\begin{array}{l}\text { Core reading program is implemented with fidelity (i.e., as per publisher } \\
\text { recommendations) }\end{array}$} \\
\hline \multicolumn{4}{|l|}{$\begin{array}{l}\text { Tier } 1 \text { instruction includes differentiated, small group work based on student } \\
\text { needs }\end{array}$} \\
\hline \multicolumn{4}{|l|}{ Intervention blocks are clearly designated in master school schedule } \\
\hline \multicolumn{4}{|l|}{$\begin{array}{l}\text { Tier } 2 \text { intervention is provided for research-recommended } 30 \text { minutes daily, } \\
\text { beyond the general instructional period, and addresses specific skills }\end{array}$} \\
\hline \multicolumn{4}{|l|}{ Tier 2 Intervention group size is $3-5$ students per interventionist } \\
\hline \multicolumn{4}{|l|}{$\begin{array}{l}\text { Tier } 3 \text { intervention is provided for research-recommended } 45-60 \text { minutes } \\
\text { daily, beyond the general instructional period, and uses a research-based } \\
\text { reading intervention program }\end{array}$} \\
\hline Intervention group size is $1-$ & & & \\
\hline
\end{tabular}

PART II: Check YES or NO for each item below at each grade level range.

\begin{tabular}{|c|c|c|c|}
\hline COLLABORATION \& PROBLEM SOLVING & $\mathrm{K}-2$ & 3-4 & $5-6$ \\
\hline $\begin{array}{l}\text { Grade level teams have common planning times for data analysis and } \\
\text { problem solving }\end{array}$ & & & \\
\hline $\begin{array}{l}\text { General education teachers, Title } 1 \text { teachers, Special Educators, LEP } \\
\text { teachers and other interventionists share responsibilities for instruction and } \\
\text { intervention }\end{array}$ & & & \\
\hline $\begin{array}{l}\text { Staff focuses on problem solving and adjusting instruction rather than } \\
\text { referring to special education }\end{array}$ & & & \\
\hline $\begin{array}{l}\text { Instruction and Intervention Teams or SAT work to make decisions such as } \\
\text { movement among tiers, need for additional resources, referral to SAT }\end{array}$ & & & \\
\hline
\end{tabular}




\begin{tabular}{|l|l|l|l|}
\hline PROFESSIONAL DEVELOPMENT & K-2 & $\mathbf{3 - 4}$ & $\mathbf{5 - 6}$ \\
\hline Teachers are trained on core reading program & $\begin{array}{l}\text { Yes } \square \\
\text { No } \square\end{array}$ & $\begin{array}{l}\text { Yes } \square \\
\text { No } \square\end{array}$ & $\begin{array}{l}\text { Yes } \square \\
\text { No } \square\end{array}$ \\
\hline Teachers are trained on data analysis for instructional decision-making & $\begin{array}{l}\text { Yes } \square \\
\text { No } \square\end{array}$ & $\begin{array}{l}\text { Yes } \square \\
\text { No } \square\end{array}$ & $\begin{array}{l}\text { Yes } \\
\text { No } \square\end{array}$ \\
\hline $\begin{array}{l}\text { Teachers are trained on explicit, systematic intervention planning and } \\
\text { delivery including, as appropriate, research based reading intervention } \\
\text { programs }\end{array}$ & $\begin{array}{l}\text { Yes } \square \\
\text { No } \square\end{array}$ & $\begin{array}{l}\text { Yes } \square \\
\text { No } \square\end{array}$ & $\begin{array}{l}\text { Yes } \square \\
\text { No }\end{array}$ \\
\hline $\begin{array}{l}\text { School-level professional development includes job-embedded } \\
\text { components such as professional learning communities and/or } \\
\text { instructional coaching }\end{array}$ & $\begin{array}{l}\text { Yes } \square \\
\text { No } \square\end{array}$ & $\begin{array}{l}\text { Yes } \square \\
\text { No } \square\end{array}$ & $\begin{array}{l}\text { Yes } \square \\
\text { No }\end{array}$ \\
\hline
\end{tabular}

Part III: With all school grade levels in mind, check YES or NO.

\section{SPECIAL EDUCATION REFERRAL \& ELIGIBILITY PROCEDURES}

School Assistance Team (SAT) understands RTI data collection requirements for special education referrals

Yes $\square$

No $\square$

School psychologist is trained in RTI procedures for designing multi-disciplinary evaluations

Eligibility Committees (ECs) are trained in making eligibility decisions using RTI procedures for the identification of students with specific learning disabilities
Yes $\square$

No $\square$

Yes $\square$

No $\square$

Part IV: Please provide the following data and respond to the reflection questions.

\begin{tabular}{|c|c|c|c|}
\hline Subgroups & $\begin{array}{c}\text { 2006-2007 } \\
\text { WESTEST } \\
\text { Reading } \\
\text { Percent } 3^{\text {rd }} \\
\text { Graders } \\
\text { Proficient }\end{array}$ & $\begin{array}{c}\text { 2007-2008 } \\
\text { WESTEST } \\
\text { Reading } \\
\text { Percent } 3^{\text {rd }} \\
\text { Graders } \\
\text { Proficient }\end{array}$ & \multirow[t]{3}{*}{$\begin{array}{l}\text { As you reflect on your WESTEST scores: } \\
\text { 1) What are your school's strengths relevant } \\
\text { to reading instruction? }\end{array}$} \\
\hline All & & & \\
\hline Sp Ed & & & \\
\hline Low SES & & & \multirow[t]{2}{*}{ What are the greatest challenges and why? } \\
\hline LEP & & & \\
\hline
\end{tabular}


Appendix G

Panel of Experts 
Appendix G

Panel of Experts

\section{Expert 1 Credentials}

Response to Intervention Specialist

MA English

Nation Board Certification in Adolescent/Young Adult Language Arts

\section{Expert 2 Credentials}

Assistant Director - Office of Research

M.A. Communication Studies Theory and Research (WVU)

B.A. Applied Communication Studies (WVU)

\section{Expert 3 Credentials}

Response to Intervention Specialist

MA Reading 
Appendix $\mathbf{H}$

RESA Support Letter 


\section{Appendix $\mathrm{H}$}

\section{RESA Support Letter}

\section{Regional Education}

ServiceAgencies

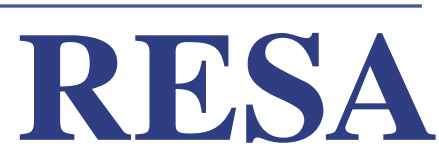

- seven •

A powerful engine for education

Gabriel J. Devono, Executive Director

1201 N. 15thStreet - Clarksburg, WV 26301

304.624.6554 ext. $221 \cdot$ Fax: 304.624.3665 • 800.427.3600 • http://resa7.k12.wv.us

July 26, 2010

TO: $\quad$ Teachers, Literacy Coaches, Principals, County Level Administration

RE: Response to Intervention (RTI) Implementation Survey

RESA 7 requests your participation in a research study that involves the following stakeholders-teachers, literacy coaches, school level administration and county level administrators responsible for RTI implementation within RESA VII.

This study will use surveys designed from the current implementation documents provided by the West Virginia Department of Education (WVDE), Office of Special Programs. While research exists on the achievement of students within the RTI framework, little is available on the implementation processes. This study will provide valuable information in regards to the implementation process as well as establish what programs counties are using for the delivery of Tier II and Tier III. This information may be used to improve implementation procedures.

SurveyMonkey.com will be used to distribute the surveys via WVDE access accounts. This study will focus on stakeholders in the twelve counties represented by RESA 7. It is our goal to garner a 100 percent participation rate. It is encouraged that all stakeholders complete the online survey by August 31, 2010.

This research project will be approved by West Virginia University. This study seeks to keep the identity of respondents anonymous; schools or individuals will not be identified. However, you will have the opportunity to respond via email if you would like to participate in a follow-up phone interview. Response in this manner allows for the survey information to remain anonymous. If you have any questions regarding this survey, please contact Tammy Samples, tsamples@mix.wvu.edu_or at 304.472.2542.

Your participation in this research is greatly appreciated. It may provide valuable information for future RTIimplementation procedures.

Barbour, Doddridge, Gilmer, Harrison, Lewis, Marion, Monongalia, Preston, Randolph, Taylor, Tucker and Upshur 
Appendix I

Investigator Credentials 
Appendix I

Investigator Credentials

\section{Investigator 1}

Education:

BA Journalism

BA Elementary Education

MA Reading Specialist

Administrator Certification

Positions held relative to current research:

Title I Teacher

Literacy Coach

Investigator 2

Education:

BA Elementary Education

MA Reading Specialist

Administrator Certification

Positions held relative to current research:

Title I Teacher

Literacy Coach 
Appendix J

Addendum 


\section{Appendix $\mathbf{J}$}

\section{Addendum}

This addendum will provide a review of the RTI initiative in WV (2005-1012), a brief review of survey data from 2010, an update of SPL, as well as perspectives from the field with regard to RTI/SPL implementation.

With the reauthorization of IDEA in 2004, West Virginia (WV) began implementing a pilot Response to Intervention (RTI) initiative in 2005. The West Virginia Response to Intervention (RTI) Project was initially designed to develop better readers in the primary grades. The program entailed three tiers of instruction with increasing levels of support. This model consisted of high quality core instruction, as well as, intervention with extended times and skill development.

As part of the WV RTI Initiative, the West Virginia Department of Education (WVDE) established An Implementation and Technical Assistance Guide for Districts and Schools, that provided a readiness checklist and implementation forms (Palenchar, Brown, \& Jennings, 2006). Additionally, the guide proposed three phases for establishing RTI throughout the state. Phase I was the initial phase of implementation and included establishing pilot schools, distribution of a guidance document, implementation timeline and establish a department and practioner collaborative. Phase II expanded the program to all elementary schools, as well as, implementation in middle schools along with expanding communication, creation of foundational and implementation documents, create monitoring and professional development support and establish and implement evaluation procedures. Phase III was to be a direct expansion to high schools with update implementation documents, continued communication and continued evaluation implementation. 
Phase I took place between 2005 and 2007 and included establishing pilot schools, developing the implementation guide, implementing timelines in WV policy, funding, and the creating of a department and collaborative to assist with expansion. Phase II (2007-2010), incorporated inclusion in all elementary schools, determined implementation in middle and high schools, developed communication at all levels, created a document repository for middle and high schools, provided funding, designed monitoring and professional development support at the state level, assessed resource capacity for elementary and middle schools, and established and implemented evaluation. Phase III (2010-2012) was to be a direct expansion to high schools, with an updated document/resource repository, continued communication, and assessment and evaluations in place (WVDE, 2007). Due to the fact that logistical concerns arose with Phase II implementation, Phase III expansion remained off schedule and before schools had an opportunity to begin effective programs, SPL was started.

As implementation occurred, it become evident that districts could not successfully implement without additional assistance. As a result, the WVDE created a new position, the RTI Specialist, in September 2009. This position was an extension of the Office of Special Programs, Extended and Early Learning, but was located in each Regional Educational Service Agency (12 agencies across WV). The duties for this position included, but were not limited to, providing professional development on RTI, examining the implementation level of each school, and assisting schools with implementation and analysis of the RTI programs that were in place. The specialists were to work with each county board of education to assist with implementation. In the largest RESA district in WV, that included 12 counties, which included 81 elementary schools, 24 middle schools and, 25 and high schools. They were to work to ensure compliance with policies, analyze data, develop, coordinate and deliver professional development, report 
monthly on status of implementation and data. This position was in place for approximately 18 months and then discontinued. The exact reason for discontinuation could not be located. However, at the time, the job expectations were varied as mentioned above and the staff could not manage entire RESA's.

As discontent with RTI implementation policies and procedures mounted in the state and student achievement gaps failed to close, the WV department of education realigned RTI and replaced it with Support for Personalized Learning (SPL) in April of 2012. This new initiative, SPL, is defined as a:

"a state-wide initiative that suggests flexible use of resources to provide relevant academic, social/emotional and/or behavioral support to enhance learning for all students. SPL is characterized by a seamless system of high quality instructional practices allowing all students to sustain significant progress, whether they are considered at-risk, exceeding grade-level expectations or at any point along the continuum (SPL guidance document, 2012, p.1)."

Prior to SPL implementation, the WVDE recognized the following eight components considered to be necessary to SPL implementation: Leadership, School Climate and Culture, Teams and Processes, Family and Community Partnerships, Assessments, Core Instruction, Targeted Instruction and Intensive Instruction. While the leadership, school climate and culture, teams and processes, and family and community partnerships were not specifically articulated in the RTI initiative, the attributes of this type of collaboration appeared to be in place. A change in terminology occurred with regard to the levels/tiers of instruction, as well as changes in requirements (Table 1 ). 
Table 1

RTI/SPL Differences

\begin{tabular}{cc}
\hline RTI Characteristics & SPL Characteristics \\
\hline Tier I & Core Instruction \\
Tier III & Targeted Instruction \\
Time Frames & Intensive Instruction \\
Tier I -60 to 90 minutes & Times Frames \\
Tier II -30 minutes, 5 days a week & Core Instruction - No required limit \\
Tier III $-45-60$ minutes, 5 days a week & Targeted $-15-30$ minutes, 3 to 5 days a week \\
----- & Intensive $-30-60$ minutes, 3 to 5 days a week
\end{tabular}

Tier I was replaced with Core Instruction, Tier II with Targeted Instruction and Tier III with Intensive Instruction. The time allocated in each area of instruction also changed with SPL implementation. With RTI, Tier I consisted of at least one hour of whole group reading instruction. WV policies (2419 and 2510) were changed to remove the time element from SPL's core instruction. Tiers II and III (now Targeted and Intensive Instruction) also had variable time limits imposed. Within RTI, Tiers II and II were allotted, 30 minutes for Tier II and 45-60 for Tier III, whereas in SPL, targeted instruction now has a range of 15-30 minutes, while intensive instruction is $30-60$ minutes.

In an effort to gain current insight from the field, with regard to the time prior to SPL, after the time frame of the original survey, and the current status of SPL implementation, I informally spoke with a classroom teacher, a reading specialist, and an elementary school principal. The following questions were asked of each interviewee: 
1. How would you characterize the implementation status of RTI during the 2011-2012 school year (emerging, making progress, established)? Why?

2. How would you characterize the implementation status of SPL during the 20122013/2013-2014 school year (emerging, making progress, established)? Why?

3. Please compare RTI and SPL. It would be helpful if you could think about this with regard to pros and cons.

4. What other comments might you make with regard to intervention/RTI/SPL?

With regard to question one, "How would you characterize the implementation status of RTI during the 2011-2012 school year (emerging, making progress, established)? Why?" both the classroom teacher and the reading specialists believed that RTI was readily established. Both reported that the guidelines for implementation were clear and easy to follow. They also reported that instruction parameters and procedures were delineated and easily understood. The reading specialists also mentioned the process/requirements for RTI were in place. The classroom teacher offered that the time frames for intervention were clear, as well as, the expectations of all stakeholders. The principal believed the RTI was continuing to make progress, but was not clearly established. In her response, she referenced that her school was moving forward and becoming familiar with the demands of scheduling, resources, and student needs. All responses with regard to these question were positive. The stakeholders interviewed were pleased with the implementation status and stated that student achievement was increasing based on assessment data.

Question two, "How would you characterize the implementation status of SPL during the 2012-2013/2013-2014 school year (emerging, making progress, established)? Why” yielded emerging implementation status from all stakeholders. Both the classroom teacher and the reading specialists reported that expectations for SPL implementation were unclear. While the reading specialists stated that while "a few" discussions were held at Title I meetings and schools, little support was given to the process or understanding of SPL. The principal added that 
while the changes were being made, the WVDE layered math, writing, and behavior into the SPL focus as well. The classroom teacher also stressed that school climate, team building, and community partnerships had become a foci. While she believed these things were important, she stressed that students were falling through the cracks as less focus is placed on targeted areas of need. All stakeholders believed that much more training is needed at all levels for successful implementation of SPL.

When asked to compare RTI and SPL procedures with reference to pros and cons on question three, all stakeholders shared multiple thoughts. These views can be seen in Table 2 . 
Table 2

RTI/SPL Pros and Cons

RTI SPL

\section{Procedural}

\begin{tabular}{|r|l|l|}
\hline Clear procedures, time frames, & \\
\hline conditions, and well defined roles & $\mathrm{X}$ \\
\hline Assessment procedures in place & $\mathrm{X}$ \\
\hline Student abilities apparent & $\mathrm{X}$ \\
\hline
\end{tabular}

\section{Stakeholders}

Stakeholder connection and "follow-

$$
\text { through" } \mathrm{X}
$$

\section{Balance of workload}

Workload for implementation with the

Reading Specialist and a team $\mathrm{X}$

collaboration

Workload for implementation with the

classroom teacher, integration in core

X

$$
\text { instruction }
$$

Rigor

Requirements were demanding $\mathrm{X}$

Less accountability and fewer 
Interview responses stated clear procedures, time frames, conditions, and defined roles were very clear with the RTI initiative, but were clearly lacking in SPL. The reading specialists added that with RTI, assessment procedures were in place and student abilities were apparent. She has also found a lack of "follow-through" from all stakeholders and a disconnection has occurred after SPL implementation. The classroom teacher reflected that from her perspective, the balance of work has shifted and classroom teachers are now responsible for the bulk of the work within core instruction with the SPL model. The principal articulated that she believed that while the requirements for RTI were demanding, that WVDE, created their own version with less accountability and fewer requirements.

When asked to offer any other comments about RTI/SPL in question four, responses continued in the same vein. The principal remarked that she has become very disillusioned with RTI/SPL. She reported that her school had not experienced a decrease in demand for support. It was also noted that students often do not ever leave intervention. The way RTI/SPL is designed, only $15 \%$ of the school population are to be in Targeted and only $5 \%$ in Intensive. If implemented properly these numbers should decrease. The reading specialist mentioned that accountability and clarity are lacking and negatively impacting implementation. She also stated that the immersion that was present with RTI is absent with SPL. The classroom teacher believed that with SPL there is far less focus on students in need.

My original survey was conducted in the Fall of 2010. At that time, most schools were four plus years into implementation of RTI. There was disparity among stakeholders about implementation status. Survey results indicated stakeholder position did effect perceived implementation status. There was little common ground between administrators and teachers on 
multiple areas of implementation. While this was highlighted within the survey results, the survey did not solicit specific reasons for the lack of congruence. The use of effective communication implies that schools that implement RTI successfully, spend necessary time in collaboration with all stakeholders. Burns and Gibbons (2012) agreed that the discussion about RTI must continue to inform decision making.

As with any initiative or innovation, numerous variables impact implementation. Within the survey results, patterns emerged with regard to the following areas: personnel, time constraints and scheduling, professional development, and appropriate funding and resource allocation. Survey respondents articulated that appropriate personnel are essential to successful implementation. These comments included, but were not limited to, providing adequate personnel to implement RTI, as well as, personnel with sufficient training which also ties closely to time for implementation and the amount of funding available to ensure fidelity of implementation. Bernhardt and Hébert (2011) affirmed that it is necessary to realign current resources with regard to personnel, time, and funding. Success is within reach, but it will be necessary for difficult conversations to take place and communication between stakeholders must become a priority.

\section{Findings}

Without fault, all stakeholders reported greater success for students and staff could be found in RTI, rather than SPL. It may also be inferred that in the year after my original survey, some of the facets of disagreement between stakeholders were eliminated and implementation status improved. All stakeholders agreed that RTI was working well and according to assessment data, students were improving. 


\section{Conclusions}

The SPL program is in its infancy, but many struggling readers are counting on this intervention program for their success. However, the state of SPL for these stakeholders appears to be in distress. With regard to the three stakeholders interviewed SPL, it is apparent that limited guidelines exist, clear procedures are not in place, and for some SPL implementation is being neglected.

\section{Implications}

This revisit of stakeholders netted a shift in stakeholder beliefs about RTI and the realignment found with SPL. A parallel can be drawn from the 2010 survey results which indicated a discrepancy between stakeholder perceptions in that although there were still some issues reported with RTI, there were indicators that supported an intervention program that was nearing highly established. However, it should be noted implementation of SPL has experienced a decline when compared to the established level of RTI. A disconnect exists between the classroom, school, district, and state levels with respect to implementation. This indicates that an honest reassessment needs to occur with SPL implementation. All levels of stakeholders must be a part of this conversation and work to toward resolving the myriad of issues. 